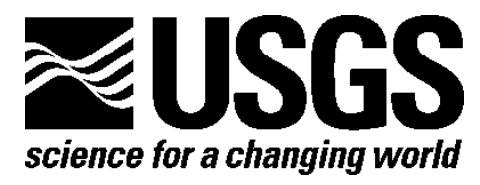

Prepared in cooperation with the National Park Service

\title{
Gap Analysis of Benthic Mapping at Three National Parks: Assateague Island National Seashore, Channel Islands National Park, and Sleeping Bear Dunes National Lakeshore
}

By Kathryn V. Rose, Amar Nayegandhi, Christopher S. Moses, Rebecca Beavers, Dawn Lavoie and John C. Brock

Open-File Report 2012-1291

U.S. Department of the Interior

U.S. Geological Survey 


\section{U.S. Department of the Interior \\ KEN SALAZAR, Secretary}

\section{U.S. Geological Survey \\ Marcia McNutt, Director}

U.S. Geological Survey, Reston, Virginia 2012

For product and ordering information:

World Wide Web: http://www.usgs.gov/pubprod

Telephone: 1-888-ASK-USGS

For more information on the USGS-the Federal source for science about the Earth,

its natural and living resources, natural hazards, and the environment:

World Wide Web: http://www.usgs.gov

Telephone: 1-888-ASK-USGS

Suggested citation:

Rose, K.V., Nayegandhi, Amar, Moses, C.S., Beavers, Rebecca, Lavoie, Dawn, and Brock, J.C., 2012, Gap analysis of benthic mapping at three national parks-Assateague Island National Seashore, Channel Islands National Parks, and Sleeping Bear Dunes National Lakeshore: U.S. Geological Survey Open-File Report 2011-1291, 60 p.

Any use of trade, product, or firm names is for descriptive purposes only and does not imply endorsement by the U.S. Government.

Although this report is in the public domain, permission must be secured from the individual copyright owners to reproduce any copyrighted material contained within this report. 


\section{Contents}

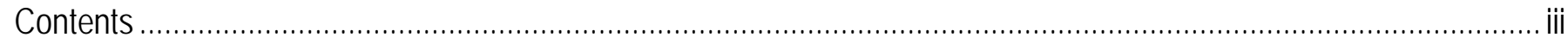

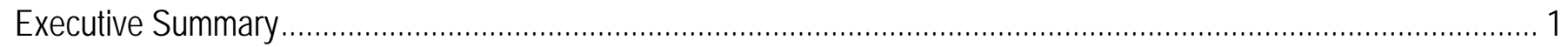

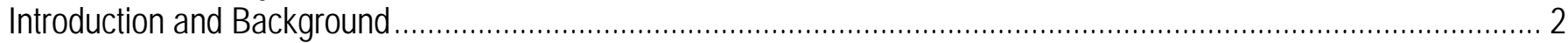

Benthic Substrate, Potential Habitat, and Habitat ............................................................................................. 4

Coastal Marine Ecological Classification Standard ……............................................................................. 5

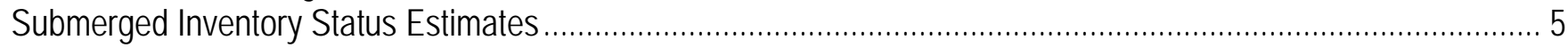

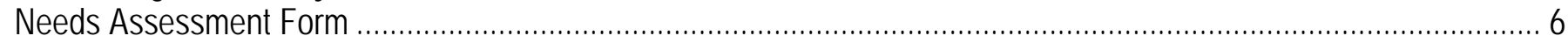

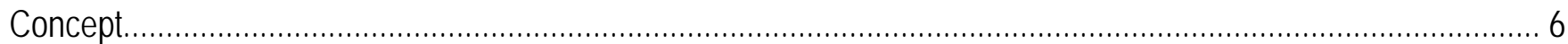

Selected Comments on the Draft Version ................................................................................................... 8

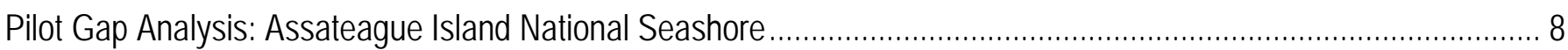

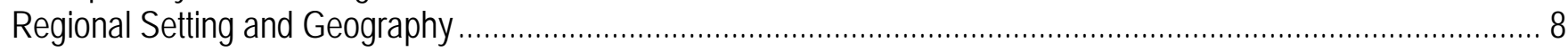

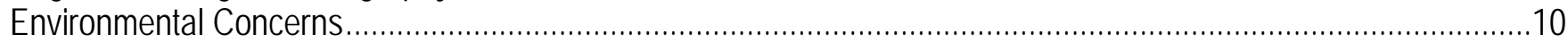

Inventory and Health Status of Benthic Resources and Communities .......................................................10

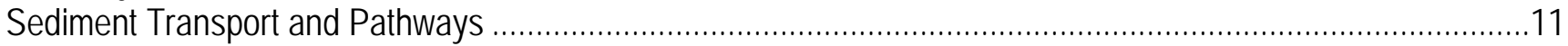

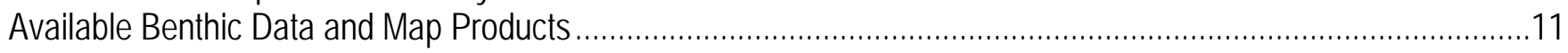

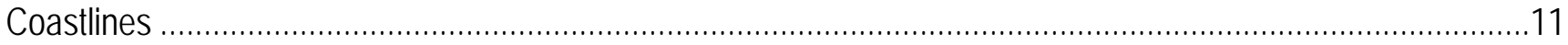

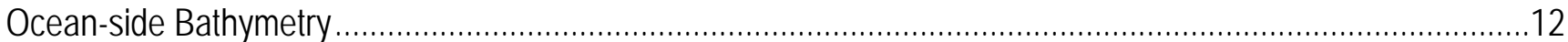

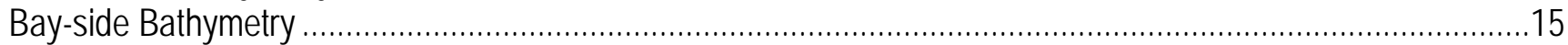

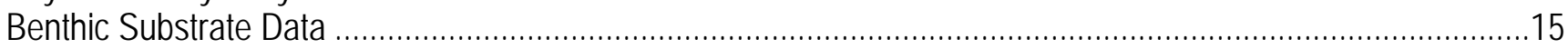

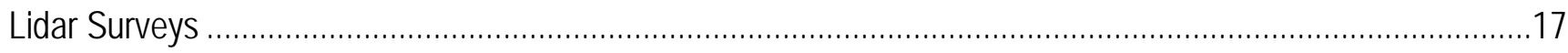

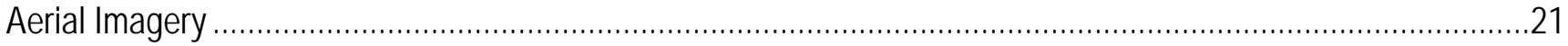

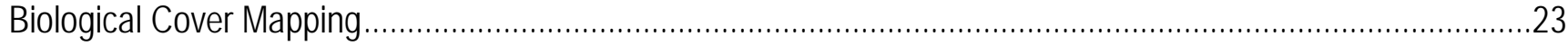

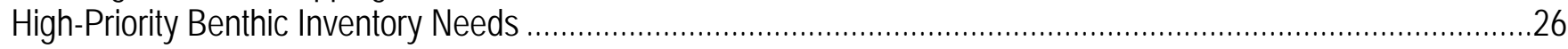

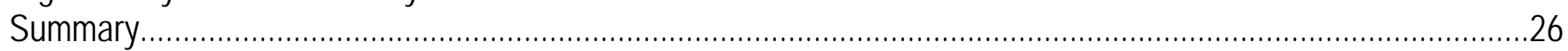

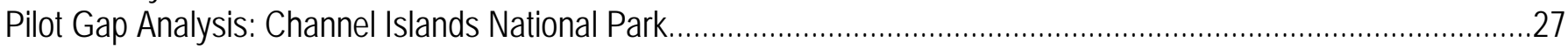

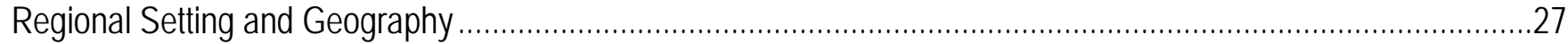

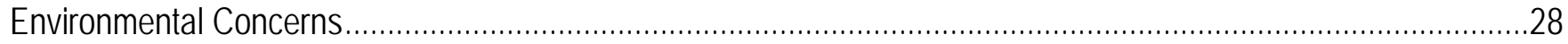

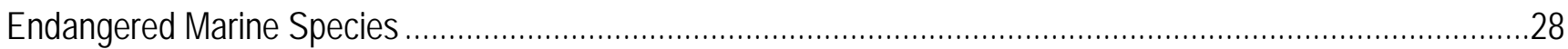

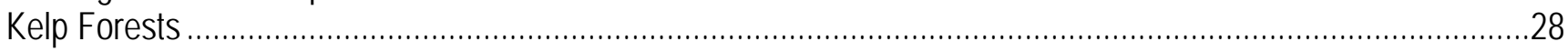

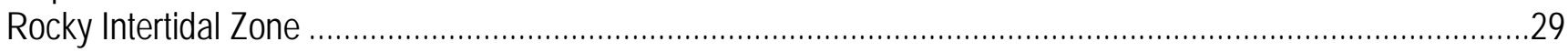

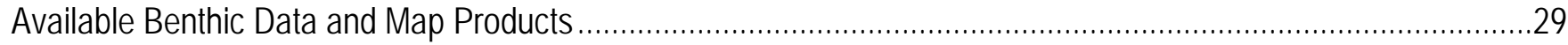

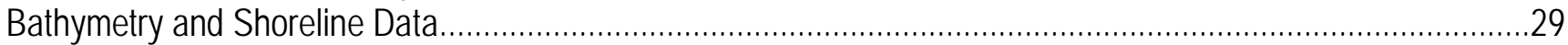

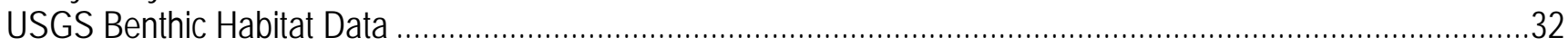

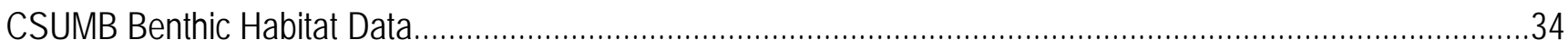

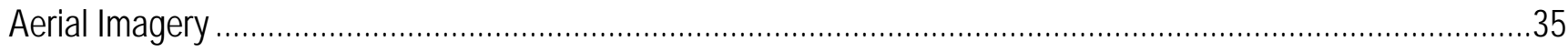

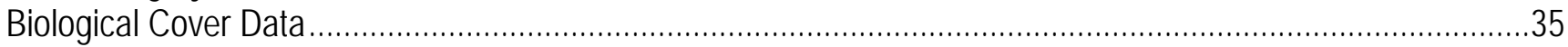

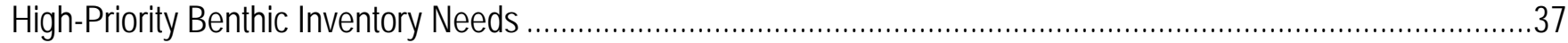

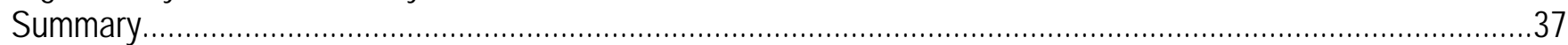

Pilot Gap Analysis: Sleeping Bear Dunes National Lakeshore ........................................................................39

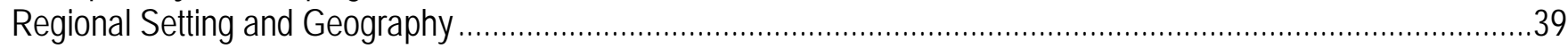

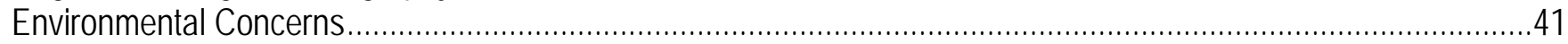

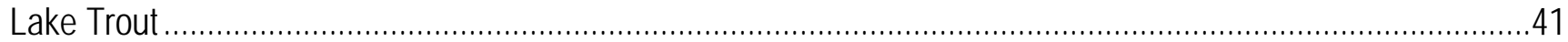

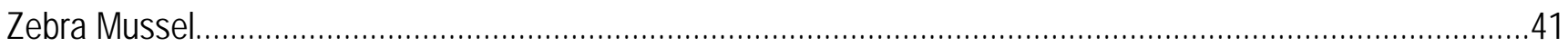

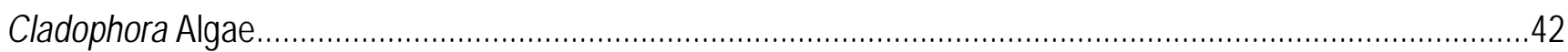

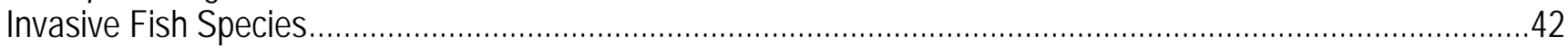

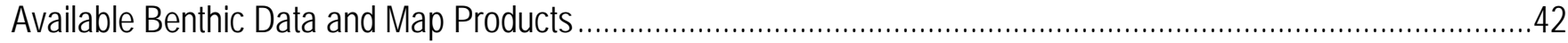

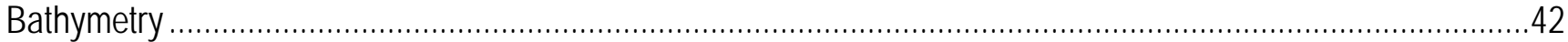




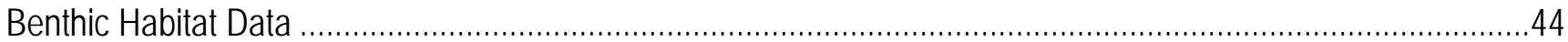

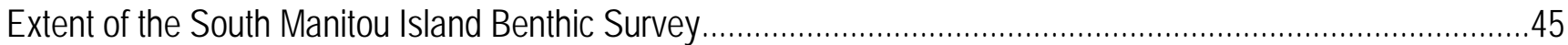

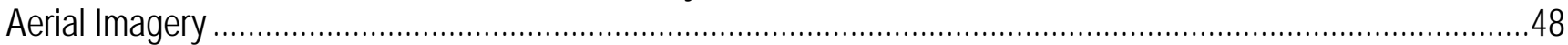

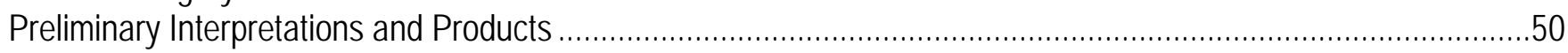

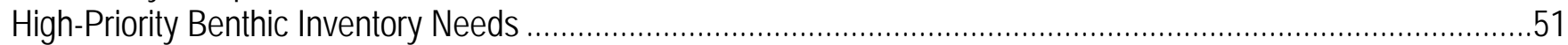

Summary

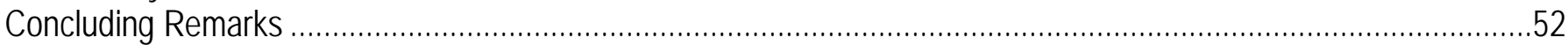

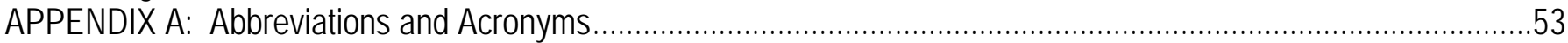

APPENDIX B: Ocean and Great Lake Parks with Submerged Acreage ............................................................56

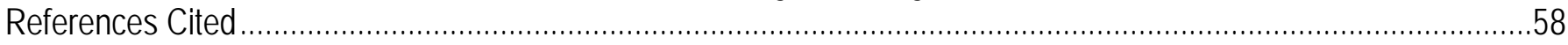

\section{Figures}

1. Map showing gap analysis pilot park locations ............................................................................ 1

2. Benthic habitat classification map from Kaloko-Honokohau National Historical Park

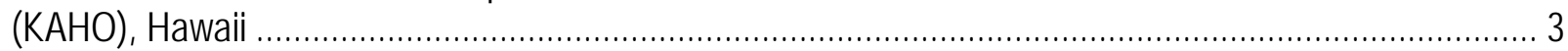

3. Draft needs assessment form as a fillable PDF for the collection of benthic survey data .....................

4. Location map of Assateague Island National Seashore with jurisdictional borders and legislative

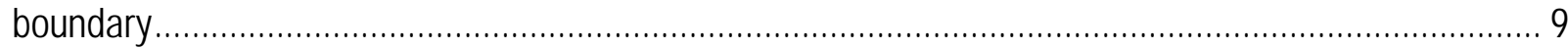

5. Map showing shoreline change (1849-2002) at Tom's Cove hook area, the southern tip of Assateague Island.

6. Map showing NOS hydrographic survey coverage used in the NOAA NGDC digital elevation model (DEM) of Ocean City, Maryland ....................................................................................

7. Map showing Maryland coastal bays and Virginia coastal bays bathymetry covering the bay side of ASIS; and the extent of USACE north end restoration bathymetry and nearshore elevation profile transects....

8. Maps showing Maryland coastal bays and Virginia coastal bays surficial substrate maps showing percentages of sand, silt, and clay in the Chincoteague Bay.......................................................... 16

9. Map showing USACE north end restoration sediment borrow and placement areas and

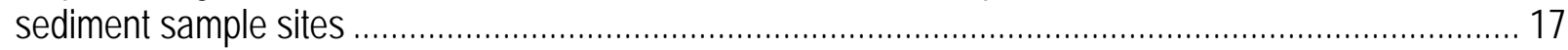

10. Map showing close-up of NASA-USGS EAARL lidar imagery. ......................................................... 18

11. Map showing USGS Earth Resources Observation and Science (EROS) Center Assateague

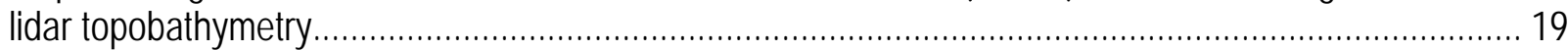

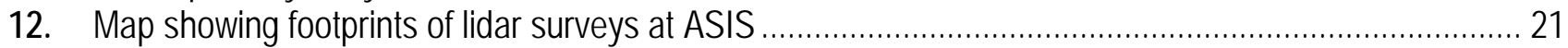

13. NASA-USGS Earth Observer 1 (EO-1) Advanced Land Imager imagery of Assateague Island, 2008 with visible subaqueous bedforms and suspended sediment................................................... 23

14. Map showing Virginia Institute of Marine Sciences 2008 seagrass bed locations and density overlain on 2000 seagrassbeds

15. Location map of the Channel Islands National Park showing the NPS and CINMS boundaries, Marine Reserves and Marine Conservation Areas........................................................................ 27

16. Histogram of CHIS submerged acreage of all habitats classified by depth .......................................... 28

17. Map showing NOS hydrographic survey coverage used in the NOAA NGDC digital elevation model (DEM) of Santa Barbara .............................................................................................. 30

18. Map showing CHIS bathymetry datasets: NOAA NGDC digital elevation model (DEM) of Santa Barbara and CSUMB bathymetry survey sites.

19. Map showing close-up of ATM II lidar and CSUMB Carrington Point bathymetry ……........................... 32

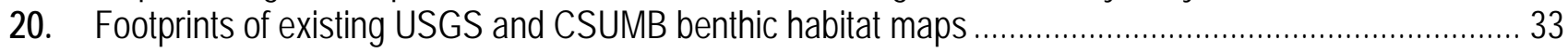

21. USGS benthic substrate map, San Miguel Island, California ............................................................. 34 
22. CSUMB benthic substrate map, Santa Barbara Island, California

23. Map showing California kelp management areas and 2008 mapped extent of kelp beds surrounding CHIS

24. Map showing CDFG 2008 kelp bed sites around San Miguel Island, California.................................... 37

25. Location map of Sleeping Bear Dunes National Lakeshore (SLBE) .............................................. 40

26. Histogram of SLBE submerged acreage of all classified habitats by depth ...................................... 41

27. Map showing NOAA NGDC 60-meter bathymetry grid of Lake Michigan with 5-meter contours ............ 43

28. Map showing extent of USACE 2005 and 2008 lidar bathymetry surveys at SLBE ............................ 44

29. Map showing planned USGS benthic habitat survey tracklines around South Manitou Island, Michigan

30. Map showing completed USGS shore-parallel sidescan survey tracklines around South Manitou Island, Michigan, 2008 and 2009. 46

31. Map showing completed USGS shore-perpendicular sidescan survey tracklines around South Manitou Island, Michigan, 2008 and 2009

32. Map showing USGS video ground-truthing sites around South Manitou Island, Michigan,2008 and 2009

33. NPS 2007 0.15-meter resolution color photography of South Manitou Island, Michigan, with visibility of up to $\sim 20$ meters deep

34. Map showing cladophora locations and abundance around South Manitou Island, Michigan

\section{Tables}

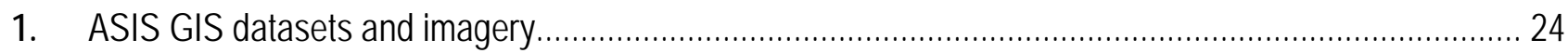

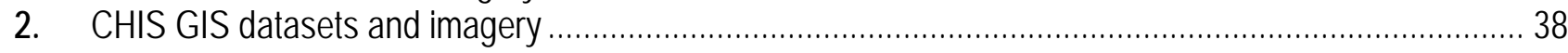

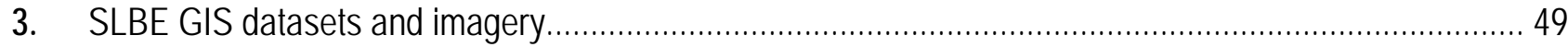




\section{Gap Analysis of Benthic Mapping at Three National Parks: Assateague Island National Seashore, Channel Islands National Park, and Sleeping Bear Dunes National Lakeshore}

By Kathryn V. Rose, Amar Nayegandhi, Christopher S. Moses, Rebecca Beavers, Dawn Lavoie and John C. Brock

\section{Executive Summary}

The National Park Service (NPS) Inventory and Monitoring (I\&M) Program initiated a benthic habitat mapping program in ocean and coastal parks in 2008-2009 in alignment with the NPS Ocean Park Stewardship 2007-2008 Action Plan. With more than 80 ocean and Great Lakes parks encompassing approximately 2.5 million acres of submerged territory and approximately 12,000 miles of coastline (Curdts, 2011), this Servicewide Benthic Mapping Program (SBMP) is essential. This report presents an initial gap analysis of three pilot parks under the SBMP: Assateague Island National Seashore (ASIS), Channel Islands National Park (CHIS), and Sleeping Bear Dunes National Lakeshore (SLBE) (fig. 1).

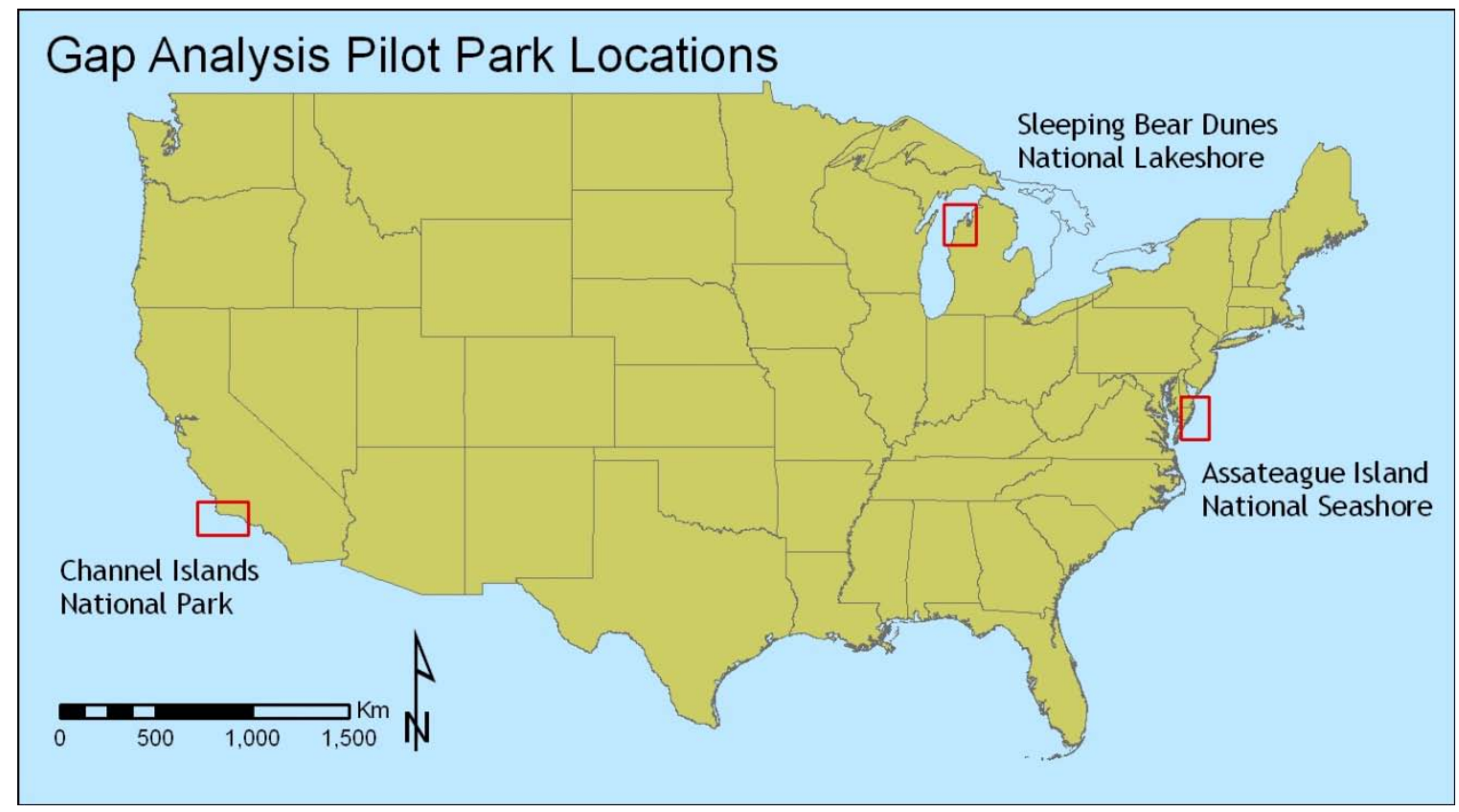

Figure 1. Gap analysis pilot park locations. 
The recommended SBMP protocols include servicewide standards (for example, gap analysis, minimum accuracy, final products) as well as standards that can be adapted to fit network and park unit needs (for example, minimum mapping unit, mapping priorities). The SBMP requires the inventory and mapping of critical components of coastal and marine ecosystems: bathymetry, geoforms, surface geology, and biotic cover. In order for a park unit benthic inventory to be considered complete, maps of bathymetry and other key components must be combined into a final report (Moses and others, 2010). By this standard, none of the three pilot parks are mapped (inventoried) to completion with respect to submerged resources. After compiling the existing benthic datasets for these parks, this report has concluded that CHIS, with 49 percent of its submerged area mapped, has the most complete benthic inventory of the three. The ASIS submerged inventory is 41 percent complete, and SLBE is 17.5 percent complete.

\section{Introduction and Background}

Coastal and marine National Park unit managers and policy makers face a growing series of complex stressors that negatively impact the natural environment within parks, including rising sea surface temperatures (SSTs) (Casey and Cornillon, 2001; Jokiel and Brown, 2004), coastal development (Hooper and others, 2005), erosion, increased nutrient influx (LaPointe, 1997; Hu and others, 2004), and even rising sea levels (Done and Jones, 2006). The first step to managing, or mitigating, any of these threats is to know with a reasonable degree of certainty the benthic resources associated with each coastal or marine park unit by mapping those resources. The benthic habitat classification map from Kaloko-Honokohau National Historical Park is an example of a map showing benthic substrate types classified as coral habitats (fig. 2). 


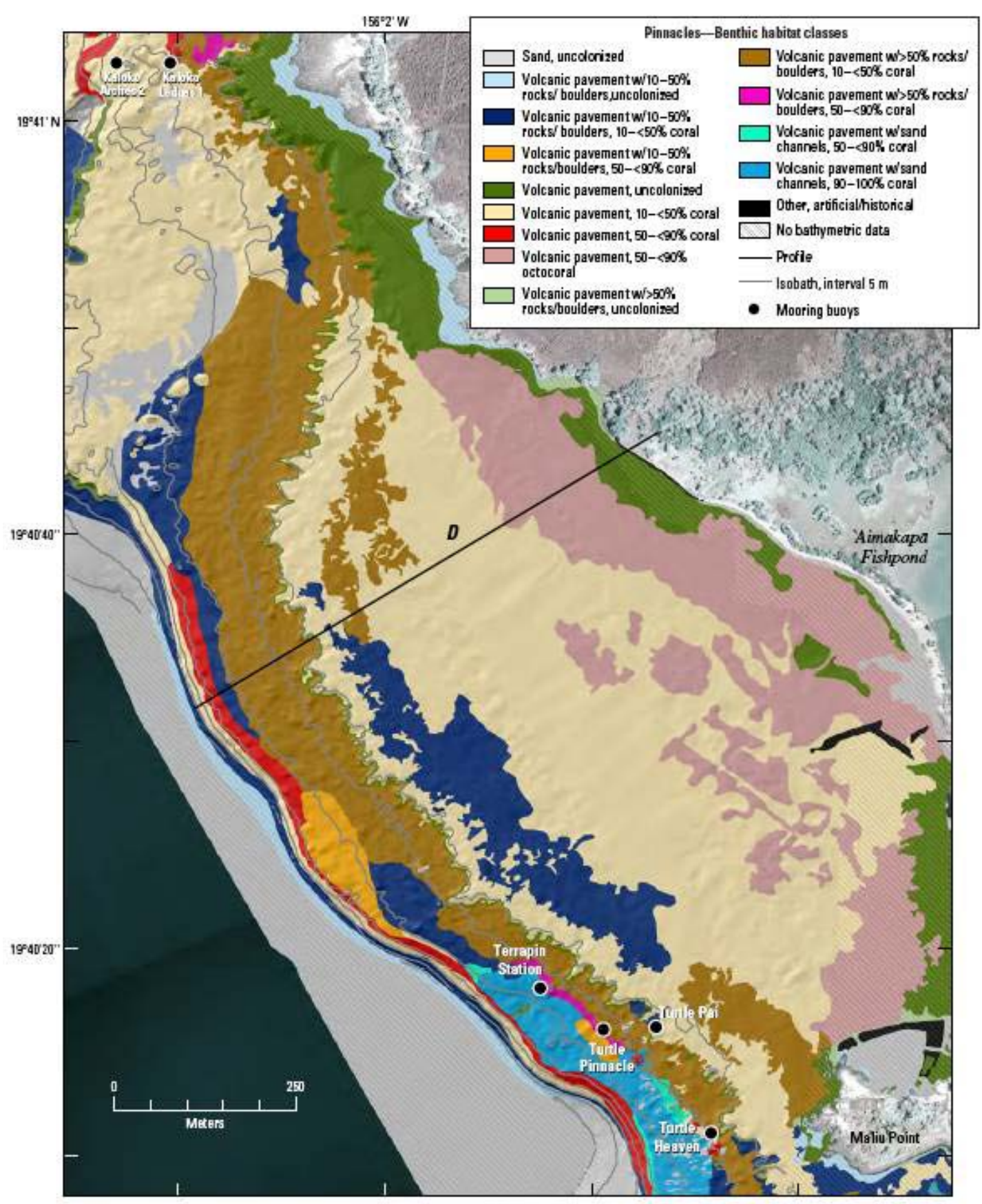

Figure 2. Benthic habitat classification map from Kaloko-Honokohau National Historical Park, Hawaii (Gibbs and others, 2007).

NPS officials identified the need for a servicewide benthic mapping program to address the lack of benthic inventory information in most ocean and Great Lakes parks. The Natural Resources Inventory and Monitoring Guidelines (National Park Service, 1999) provide the standards expected for NPS I\&M programs and products but do not explicitly identify the inventories. In December 2006, the NPS I\&M Advisory Committee (IMAC) supported an ocean and Great Lakes mapping program. As a result, it became clear that inventory of coastal resources requires a dedicated program to address the 
complex nature of data collection, processing, and interpretation. The IMAC recommended a specialized Servicewide Benthic Mapping Program (SBMP) funded by resources from the NPS I\&M program. Guidelines for the inventory and mapping of submerged resources through the SBMP are described in detail in Moses and others (2010).

Benthic habitat maps are the foundation for the protection and management of coastal parks. The first step is to define the coastal habitats or environments (that is, classes) that are present, followed with a geospatial inventory of nearshore habitat mapping resources to provide baseline data for monitoring. The benthic maps will also identify baseline conditions for post-incident (storms, ship groundings, oil spills) management decisions. With these products, network or regional I\&M managers can provide incident management teams with the necessary information to take informed actions as they supervise the recovery of benthic resources.

The rationale for establishing a distinct marine inventory and mapping program stems from the complexities of coastal and Great Lakes benthic environments, which fall into two broad categories: (1) technology and (2) commingled resources and features. The technical complications are perhaps most strongly manifested in the cost of working in the marine environment, where acquisition and processing of data can easily cost hundreds of thousands of dollars. Even after such a large initial expense, the validation and interpretation of the collected data add additional time and personnel costs.

Physical oceanography (temperature, salinity, depth), geologic characterization including subsurface structure, surface sediments, and morphology, and surface biology are requisite variables needed to identify the "habitat" in the marine environment. In essence, benthic habitat mapping requires completion of several existing NPS I\&M inventories for an individual park before any of the park’s benthic “habitat” features can be resolved. However, many signals from various types of remote sensing of the seafloor can indicate only "potential habitat” rather than an actual habitat (Greene and others, 2007). For example, acoustic data may indicate broken columnar basalts on the edge of a larger pinnacle. This could be classified as a potential yelloweye rockfish habitat because of their known affinity for those features in a particular geographic location. However, whether or not the site actually is a yelloweye rockfish habitat may also depend on the season, water temperature, and other temporally variable conditions.

\section{Benthic Substrate, Potential Habitat, and Habitat}

Managers and scientists frequently disagree with each other over definitions of "habitat." The focus for the disparate definitions revolves around the relative influence of biotic and abiotic factors in describing a habitat (Cogan and Noji, 2007). For this document, and the NPS SBMP, the following definitions are used:

habitat: a spatially distinct place or environment, defined by biotic and abiotic factors, where an organism or community of organisms naturally lives and grows.

substrate: the dominantly geological base on which an organism or community of organisms attaches or grows, such as unconsolidated sediments, boulders, or rock outcrops.

Based on these definitions, most of what is actually mapped by geophysical remote sensing (satellites, aircraft, sonar) is actually substrate or potential habitat rather than habitat. For example, a satellite image of a coral reef area is mapped as two classes of substrate: sand and coral. The product is considered a substrate map that may also indicate potential habitat. Sand, although a substrate, may provide habitat for benthic infauna if other environmental attributes are favorable. The coral class defines the carbonate structure of the coral as substrate, but the substrate also necessarily provides habitat for coral-forming organisms. Additionally, the coral subclass may also include many other habitats (for example, soft coral habitat, hard coral habitat, yellow-tail snapper habitat). To actually 
define a true habitat requires further information about each environment. Without validation by ground-truthing, the coral reef habitat defined from a remote sensing perspective is still potential habitat (Moses and others, 2010).

\section{Coastal Marine Ecological Classification Standard}

To accommodate the complexities of classifying all the variables within the benthic environment in park units distributed across 26 States and territories, the NPS may adopt the Coastal Marine Ecological Classification Standard (CMECS) Version III (Madden and others, 2008), developed by the National Oceanographic and Atmospheric Administration (NOAA) and NatureServe, for the SBMP. CMECS has been reviewed and revised by the Federal Geographic Data Committee (FGDC), which released it as a potential national standard for coastal habitat classification for public review in August 2010. Since the final version is not expected to differ substantively from the third draft version, NPS is proceeding with implementation of mapping protocols based on CMECS Version III (Moses and others, 2010). CMECS provides a framework for describing the physical and biological attributes of U.S. coastal and marine environments across spatial scales ranging from 1 square meter $\left(\mathrm{m}^{2}\right)$ to 10,000 square kilometers $\left(\mathrm{km}^{2}\right)$. The system is designed so that mapped attributes from different classes and subclasses can overlie each other, stressing the relationships and interactions in the marine environment. The principal elements of CMECS are the Benthic Cover Component (BCC) is a hierarchal classification comprising further subdivisions of Systems, Subsystems, Classes, Subclasses, and Groups that describe the ecological relationships between the organism (Group) and its environment (System) (Madden and others, 2008).

the Water Column Component (WCC) describes the highly variable structure and processes within the water column that determine the distribution and condition of the biota (Madden and others, 2008).

the Geoform Component (GFC) describes the geometric relief of the coastline and seafloor. Features can be classified as anthropogenic (dredged channels) or naturally occurring geoforms and range in scale from microforms to physiographic provinces (Madden and others, 2008).

the Surface Geology Component (SGC) describes substrate characteristics of the first few centimeters of the seafloor, classifying the benthic surface into either a consolidated (hard) class or unconsolidated (soft) class. The SGC was devised to complement the BCC, so that both biotic and abiotic aspects of the marine environment can be mapped together to illustrate the interaction between organism and environment (Moses and others, 2010).

the Sub-Benthic Component (SBC) divides the subsurface sediment into two zones-the upper 15 centimeters $(\mathrm{cm})$ below the surface and the lower $15 \mathrm{~cm}$-and is used to categorize characteristics, including sediment texture, composition, structure, and infauna (Moses and others, 2010).

As CMECS proceeds through the FGDC review, feedback from trial implementation of the scheme will be used to appraise and improve the scheme.

\section{Submerged Inventory Status Estimates}

The SBMP demands high standards for a park to be considered "completely mapped.” For the initial submerged resources inventory, however, the park unit's submerged acreage need only be fully mapped for bathymetry, biological cover, and surface geology components. The percentage completed of the initial submerged inventory $\left(I_{o}\right)$ is calculated as:

$$
I_{o}=0.25(Z+B+G+S)
$$


where

$Z$ is the percentage mapped (by area) of bathymetry,

$B$ is the percentage mapped (by area) of biological cover,

$G$ is the percentage mapped (by area) of geoform components, and

$S$ is the percentage mapped (by area) of surface geology components.

\section{Needs Assessment Form}

\section{Concept}

For the purposes of this gap assessment, a draft version of a needs assessment form was developed and circulated to contacts at each of the three pilot parks. The form was generated as a fillable PDF with buttons to print or submit (via e-mail) the completed form (fig. 3). An improved form could be sent to all coastal and Great Lakes parks for feedback and updates on benthic mapping. Conceivably, such a needs assessment could be part of an annual benthic mapping report from each coastal park. 

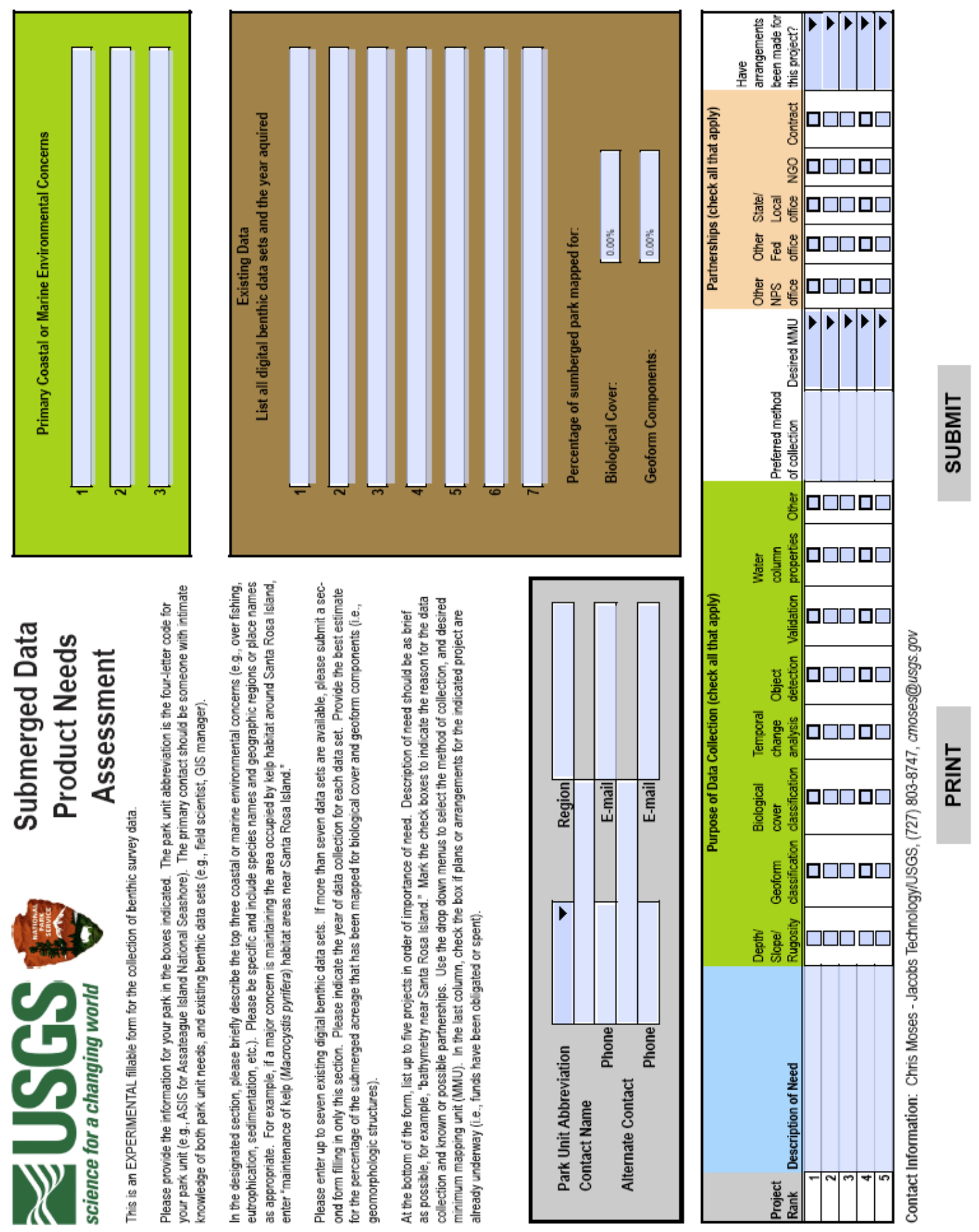

Figure 3. Draft needs assessment form as a fillable PDF for the collection of benthic survey data. 


\section{Selected Comments on the Draft Version}

The following comments are summarized from the feedback of several individuals at the three pilot parks. These remarks will provide input to further develop and improve this survey instrument.

- The form needs clearer instructions included either on the form or in the issuing e-mail. Specifically, each section needs better instructions, explaining all the options.

- The shortness of the form is appealing, but it needs to be designed carefully with good instructions to assure systematic responses.

- The list of what qualifies for the "Existing Data" section needs to be narrowed down, or lists will be too long and will take too much time to compile.

- How to calculate the "percentage mapped" needs to be explained clearly so that numbers from different parks can be compared directly.

\section{Pilot Gap Analysis: Assateague Island National Seashore}

\section{Regional Setting and Geography}

Assateague Island, one of a chain of barrier islands along the coasts of Maryland and Virginia, stretches nearly $60 \mathrm{~km}$ in a mostly northeast-southwest direction, separated from the mainland by Chincoteague Bay. Assateague Island National Seashore (ASIS) has $138 \mathrm{~km}$ of coastline and about 126 $\mathrm{km}^{2}$ of submerged resources within the park boundaries, including both estuarine (freshwater influenced) and oceanic (open marine) benthic environments. ASIS spans the Virginia-Maryland border: the southern $\sim 25 \mathrm{~km}$ that comprise the Chincoteague National Wildlife Refuge, managed by the U.S. Fish and Wildlife Service (USFWS), lie in Virginia. The remainder to the north lies in Maryland and is managed by the NPS. Within the Maryland borders of the island, $\sim 1.9 \mathrm{~km}^{2}$ of the island belong to Assateague Island State Park, managed by the Maryland Department of Natural Resources (MD DNR), and a small area $\left(\sim 0.6 \mathrm{~km}^{2}\right)$ on the bay side, close to the Virginia border, is managed by the USFWS. Due to constant shoreline change, the legislative boundary of the island must be updated periodically. The shoreline as measured in 1998 is the current legal boundary (fig. 4). 


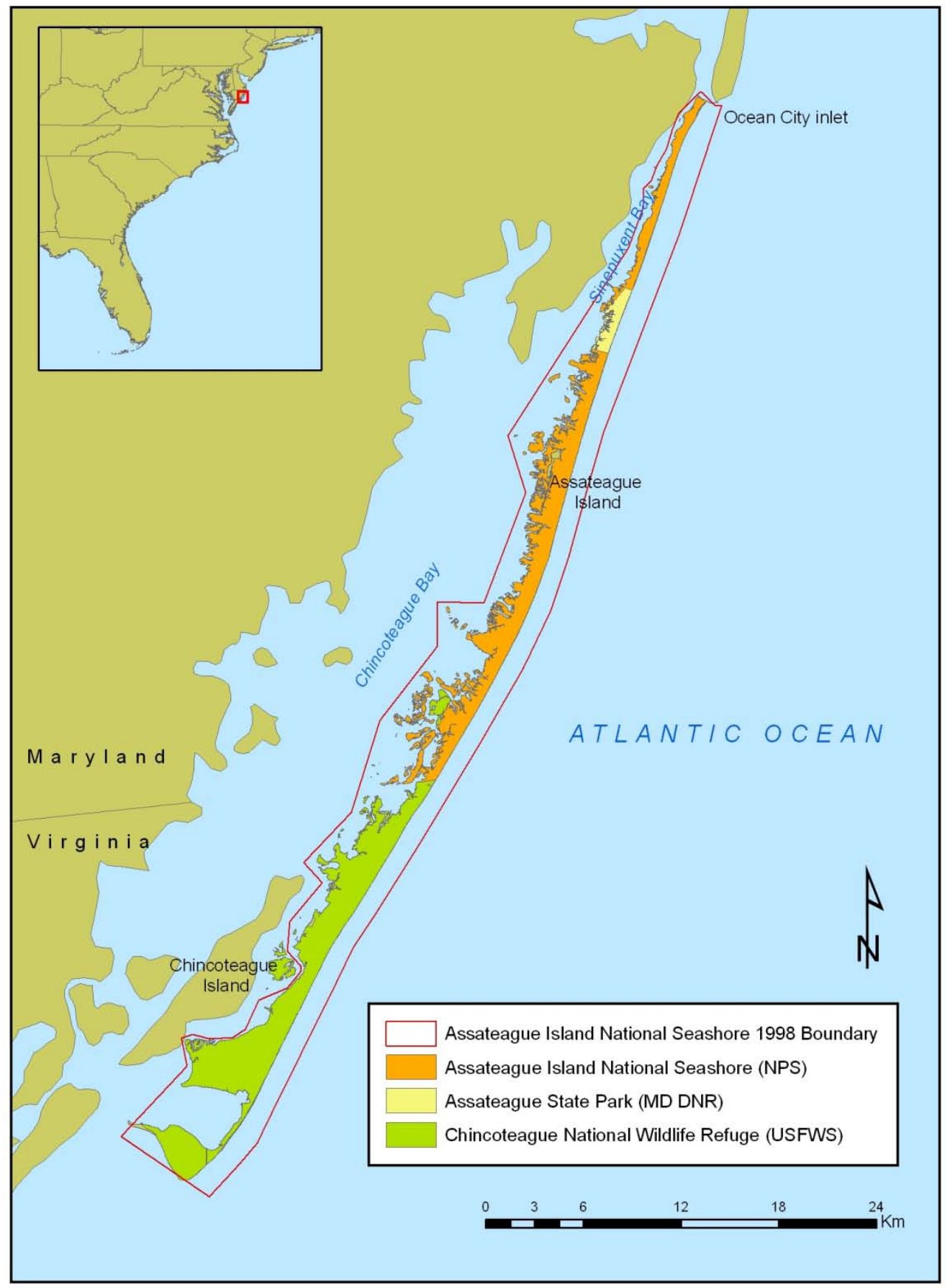

Figure 4. Location map of Assateague Island National Seashore (ASIS) with jurisdictional borders and legislative boundary.

Sandy barrier islands like Assateague are geomorphically dynamic and shaped in response to seasonal and long-term wind and weather patterns, natural and anthropogenic alterations to the 
hydrology and sediment-transport regimes, and changes in sea level. Typically, barrier islands rely on nearshore transport of sediment to renourish a naturally eroding shoreface that is constantly altered by ocean waves and currents. Nearshore sediment transport is gradually forcing Assateague Island to migrate, as updrift erosion and downdrift accretion steadily shift the shoreline southward. Since the 1850s, deposition at the south end of the island has constructed a large recurved spit, currently enclosing Tom's Cove (fig. 5).

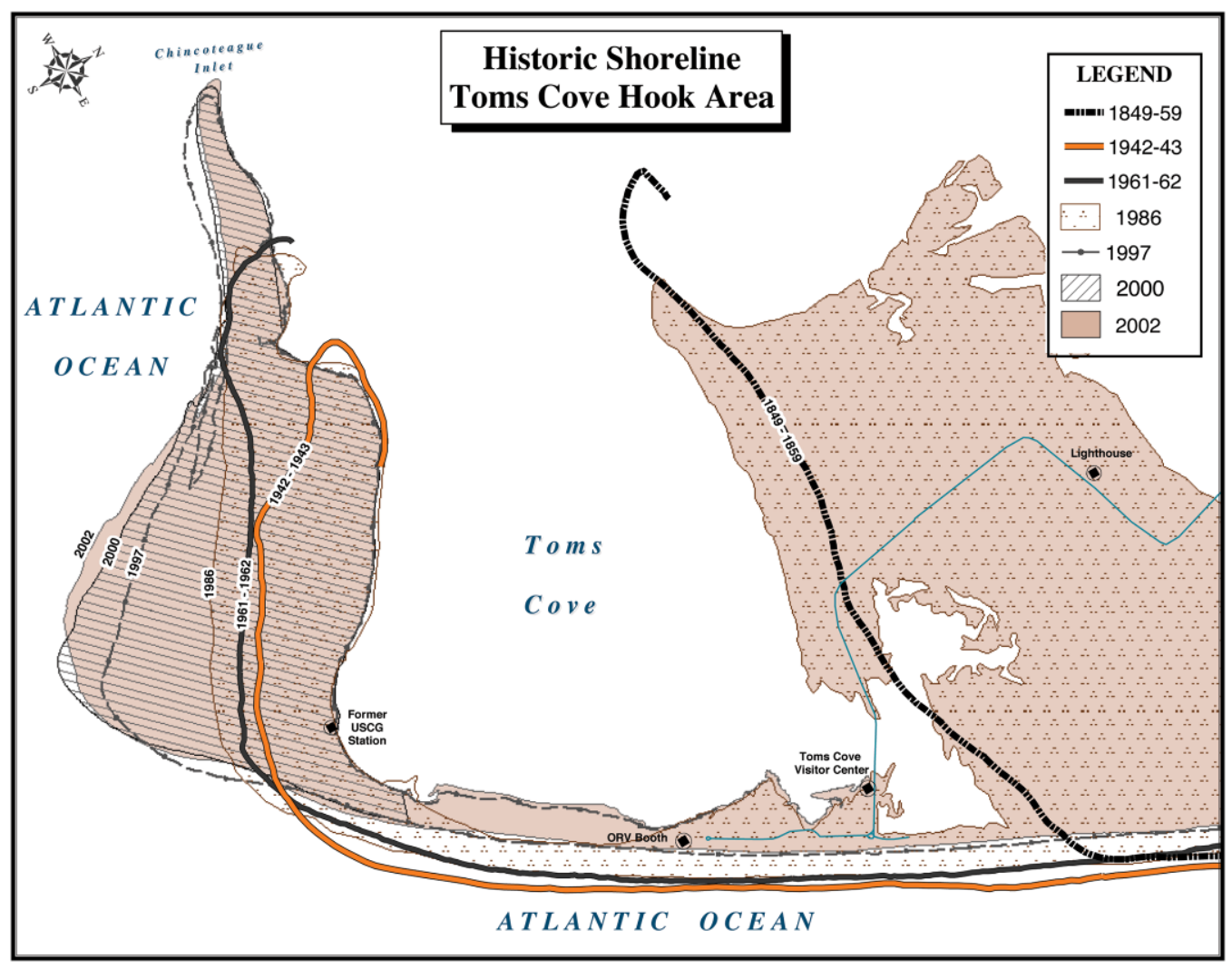

Figure 5. Shoreline change (1849-2002) at Tom's Cove hook area, the southern tip of Assateague Island (from NPS, http://www.nps.gov/asis/planyourvisit/maps.htm).

Strong winter storms can significantly alter shoreline appearances and the structure of submerged sediment deposits. Sea-level rise and overwash events (severe storms that build up large waves approaching the shoreline directly) force westward migration of the island toward the mainland, as sediments from the ocean-side shoreface are transported to the estuarine side of the island.

\section{Environmental Concerns}

\section{Inventory and Health Status of Benthic Resources and Communities}

Identifying the current state of submerged resources and habitats provides crucial baseline information for monitoring aquatic resources. The park's waters are open to commercial and recreational fishing and shellfish dredging, as well as a wide variety of recreational activities. Erosion from storms, currents, and sea-level rise is expected to continue in the future. Monitoring impacts to the 
park's ecosystems from these processes will help manage and preserve the health and diversity of its natural populations.

\section{Sediment Transport and Pathways}

The movement of sediment within the island system is a major concern to park managers. Historically, Assateague Island was part of a continuous barrier that extended north of Ocean City, Md. During a hurricane in 1933, the barrier was breached, forming the Ocean City Inlet with Assateague Island to the south and Fenwick Island to the north. The inlet was stabilized with jetties to maintain a navigable channel into the back-barrier bays. The jetties have deprived Assateague of material required to replenish the sediment lost to normal ocean wave and current erosion and transport. As a result, the ocean-side shoreline has rapidly migrated landward, past the original position of the lagoon-side shoreline. Between the 1930s and about 2000, the island migrated westward at an average rate of around $3 \mathrm{~m}$ per year, one of the fastest rates on record (Rosati and Ebersole, 1996). Landward retreat of the island has rapidly changed locations of available benthic habitats along both the ocean and back-barrier coasts and has reduced essential subaerial habitat and nesting grounds for federally endangered bird species. The north end of Assateague is disproportionally affected due to its proximity to the jetties, eroding to an extent that has left it vulnerable to breaching by storm or tidally induced inlets. Further segmentation of the island would accelerate changes in the hydrology and ecosystems of ASIS, the adjacent islands, passes, and mainland and would reduce protection from storms and extreme tides.

In 2002, the Bureau of Ocean Energy Management, Regulation and Enforcement (BOEMRE; http://www.boemre.gov), U.S. Army Corps of Engineers (USACE), and NPS began a 25-year project of beach renourishment along the northern $13 \mathrm{~km}$ of ASIS every fall and spring to mitigate the severe landward migration. The north end restoration project includes a "short-term" action consisting of direct sediment renourishment to the eroded beach and a "long-term sand management" plan that attempts to mimic the natural sediment supply system. To accomplish this, sediment is dredged, primarily from the Ocean City Inlet ebb tidal delta, and placed in the nearshore zone. Monitoring efforts employ bathymetric surveys and sediment sampling at the dredge site and shoreline profiles and elevation surveys along the north end (NPS, 2006).

\section{Available Benthic Data and Map Products}

ASIS data and product sources described in paragraphs 1-21 below are listed in table 1 (at the end of this section).

\section{Coastlines}

1. Historic shorelines from 1849 to 1989 were digitized by the Maryland Geological Survey (MGS) using National Ocean Service (NOS) coastal-survey maps and maps from the "Historical Shorelines and Erosion Rates Atlases” (Conkwright, 1975). Vector shorelines are available for the three 7.5' quadrangles (Ocean City, Tingles Island, and Whittington Point) that cover the Maryland extent of Assateague Island (Maryland Geological Survey, 2000).

2. A digitized shoreline taken from the original map was used to delineate the first legal boundary of ASIS in 1972.

3. Digitized shorelines were extracted from aerial photography and enhanced with GPS surveys. The vector shorelines represent data available for 2003, 2003-2005, and 1993-2002. 
4. GPS shoreline segments were taken two to six times per year from 1995 to 2010. Segments from 1994 to 1996 are restricted to the north end back-barrier and Maryland segment of the ocean shoreline. All of the following years' surveys include at least one line covering the entire ocean shoreface and the bay side of Tom's Cove at the southern end.

\section{Ocean-side Bathymetry}

The ocean-side boundary of ASIS is defined as being $0.8 \mathrm{~km}$ seaward of the mean high water (MHW) line. Water depth at the ocean-side boundary generally slopes from the shoreline to 8 to $10 \mathrm{~m}$. Constant landward migration of the island, primarily on the Virginia (southern) end, however, results in a synchronous landward shift of the ocean-side boundary, causing a transition of ASIS's submerged acreage to a shallower marine environment. Water clarity is very low on the ocean side, and lidar is generally only available to depths of $<1 \mathrm{~m}$, so bathymetry must be acoustically derived.

5. A digital elevation model (DEM) of Ocean City, Md., a $1 / 3$ arc-second ( $10 \mathrm{~m})$ interpolated bathymetry grid, was generated by the NOAA National Geophysical Data Center (NGDC) to support tsunami inundation modeling. The DEM grid is compiled from NOS hydrographic surveys from 1880 to 2004 (fig. 6) and USACE hydrographic survey soundings collected from 2006 to 2007 in the inlet and adjacent bay. The spacing between actual soundings can range from 200 to 2,000 m, resulting in a coarse basis for interpolation (Medley and others, 2009). 


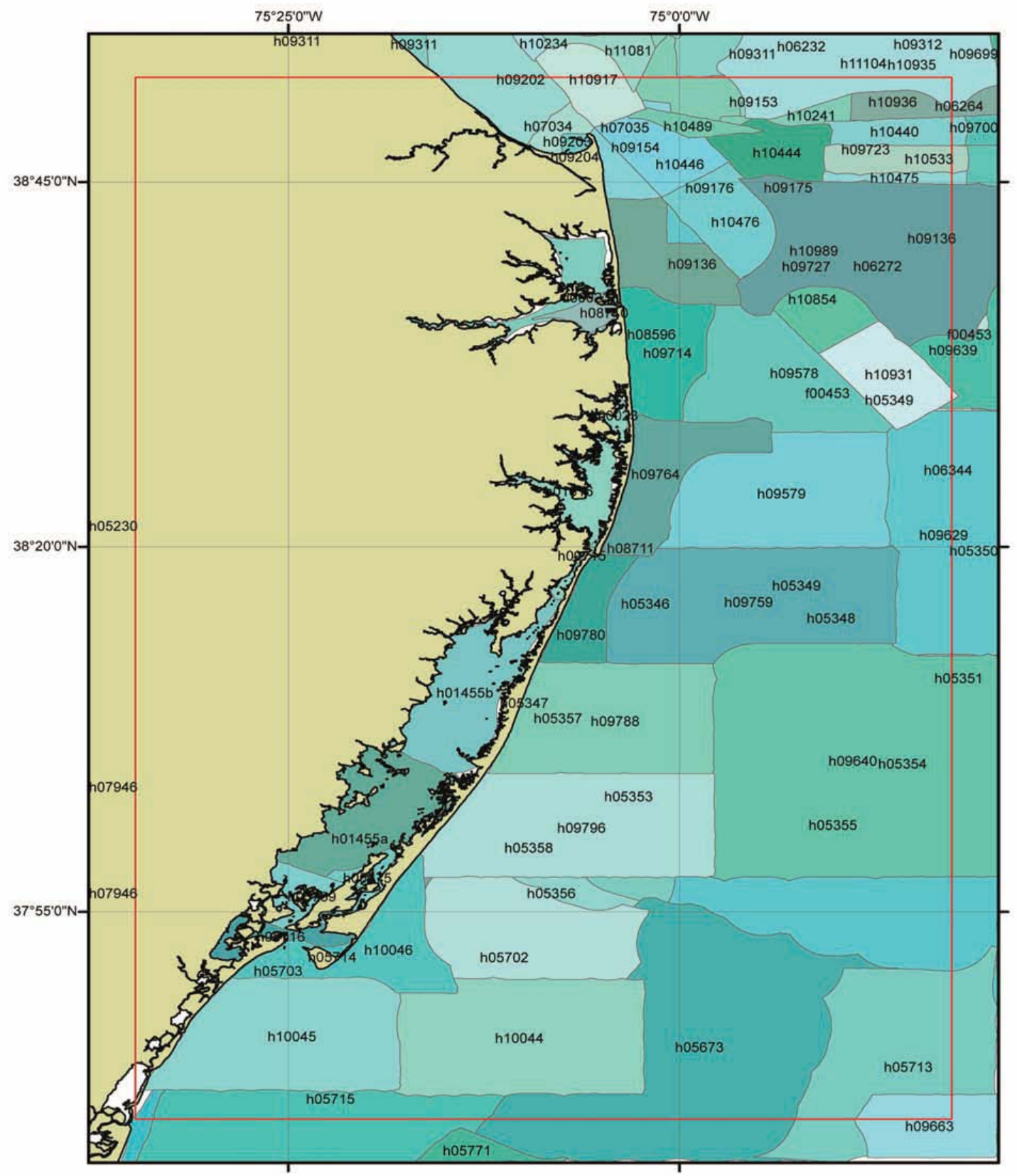

Figure 6. NOS hydrographic survey coverage used in the NOAA NGDC digital elevation model (DEM) of Ocean City, Maryland (Medley and others, 2009).

6. North end bathymetry: multibeam acoustic bathymetry grids (2-m horizontal, 1-m vertical resolution) were collected by the USACE to monitor borrow and placement sites for the north end restoration project (fig. 7). The grids cover the Ocean City Inlet and ebb tidal delta (borrow sites) and approximately $18 \mathrm{~km}$ of the north end ocean-side nearshore. The borrow sites were surveyed at least once yearly since 2004, and the nearshore site once in 2009. 


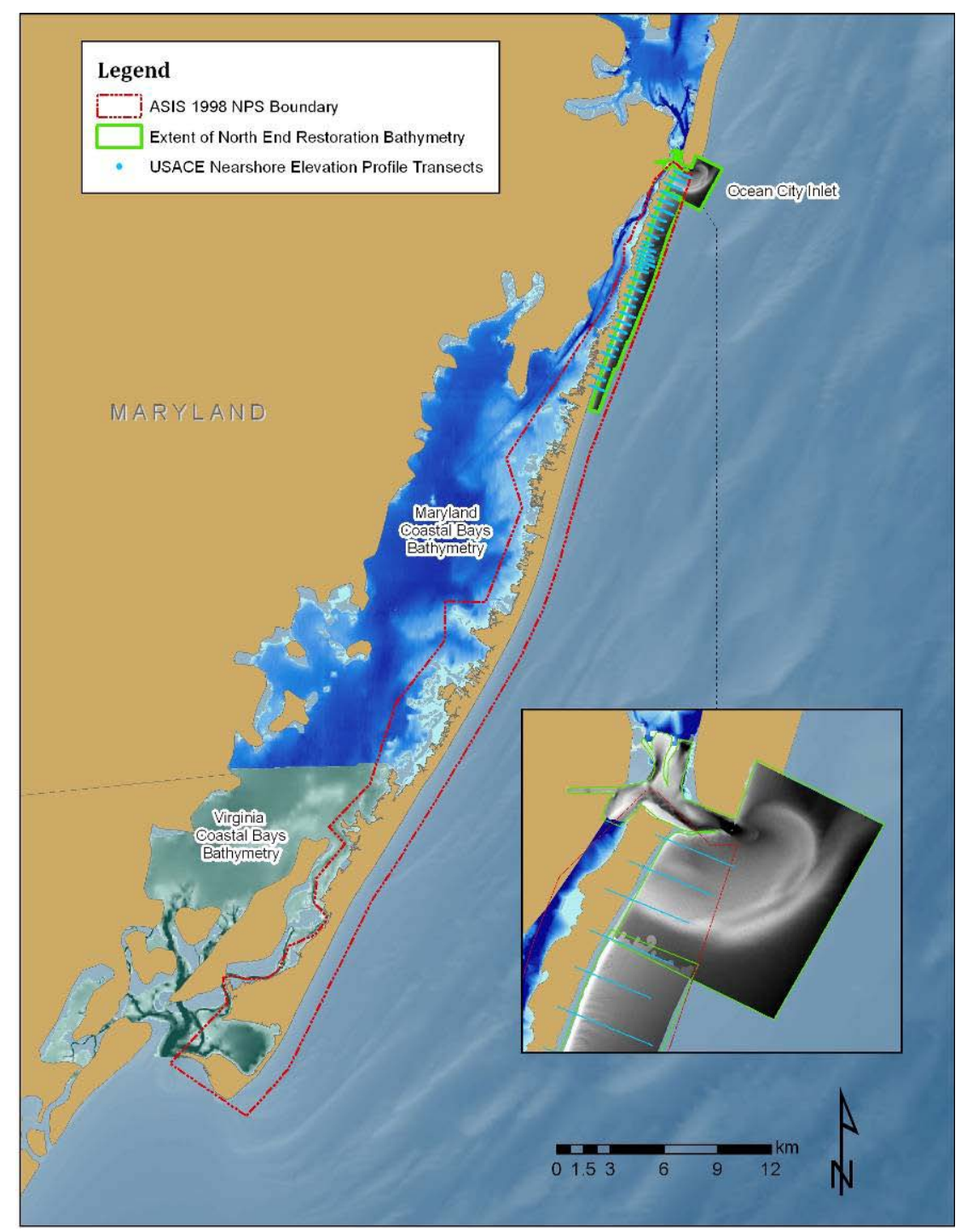

Figure 7. Maryland coastal bays and Virginia coastal bays bathymetry covering the bay side of ASIS and the extent of USACE north end restoration bathymetry and nearshore elevation profile transects. Background bathymetry is the NOAA digital elevation model of Ocean City, Maryland. Inset: close-up of USACE bathymetry at Ocean City Inlet.

7. USACE nearshore profile elevation points were collected in 2003-2005 and 2007-2009 to monitor volumetric changes resulting from sediment nourishment during the north end restoration project (fig. 7). Cross-shore profiles were obtained using an Offshore \& Coastal Technologies, Inc.-East Coast (OCTI-E) beach profile surveying system consisting of a towable sled and a land-based survey station. The system is capable of measuring seamless elevation transects from beach into approximately $10 \mathrm{~m}$ of water. Transects were collected along the northern $13 \mathrm{~km}$ of Assateague Island and extended from the upper beach to the depth of closure. The transect spacing ranges from $\sim 300 \mathrm{~m}$ to $\sim 900 \mathrm{~m}$ apart and extends up to $\sim 100 \mathrm{~m}$ offshore. 


\section{Bay-side Bathymetry}

The most recent bathymetry for Chincoteague and Sinepuxent Bays consists of interpolated grids derived from bathymetric point data collected during acoustic surveys for the Maryland and Virginia coastal bays programs under the U.S. Environmental Protection Agency (EPA) National Estuary Program. Together, the two grids provide consistent baseline bathymetry for the bays between ASIS and the mainland.

8. Maryland coastal bays bathymetry-A bathymetric grid of the northern three-fourths of Chincoteague Bay was created with 10-m horizontal resolution (fig. 7). Surveys were conducted in 2000 and 2003 following east-west transects from shore to shore spaced approximately $400 \mathrm{~m}$ apart with perpendicular tie-in lines spaced roughly 1,000 m apart. Waters less than $0.5 \mathrm{~m}$ deep were not surveyed. Soundings were obtained with a Knudsen 320BP dual-frequency echosounder in combination with a differential GPS system to ensure sub-centimeter vertical accuracy and submeter horizontal accuracy.

9. Virginia coastal bays bathymetry-A bathymetric grid of the southern quarter of Chincoteague Bay was created with 10-m horizontal resolution (fig. 7). Surveys were conducted in July and August 2006 following the same protocols as used for the Maryland coastal bays survey, except that the perpendicular tie-in lines were spaced 2,000 $\mathrm{m}$ apart.

\section{Benthic Substrate Data}

Surficial sediment data were also collected under the Maryland and Virginia coastal bays programs. A series of maps depicting sand, silt, and clay distributions was produced by ASIS Natural Resource Management GIS (fig. 8).

10. Maryland coastal bays-GIS multipoint data for surface sediment composition of the northern threefourths of Chincoteague Bay were created with 10-m spatial resolution. This dataset compiles samples collected between July 1991 and December 1997:

- a total of 988 surface samples and 346 samples taken from 32 cores were analyzed for grain size, mineralogy, and select trace metals. Samples processed for grain size were classified using the Shepard (1954) scheme based on percentage of sand, silt, or clay, and

- an additional 411 samples were taken in Chincoteague and Sinepuxent, Isle of Wight, and Assawoman Bays analyzed for grain size distribution using Folk (1954) statistics but were not classified.

11. Virginia coastal bays - GIS maps of surface sediment composition were made for the southern quarter of Chincoteague Bay. A 500-m by 500-m sampling grid was used to determine the collection sites of 269 samples that were analyzed for grain size, mineralogy, and select trace metals. Sediment was classified using the Shepard (1954) scheme based on percentage of sand, silt or, clay.

12. Sediment bypassing events - Samples were taken from locations of sediment borrow and placement sites related to the north end restoration project and were processed for grain size (fig. 9). Dredging took place once in 2004, then twice a year between 2005 and 2009. 

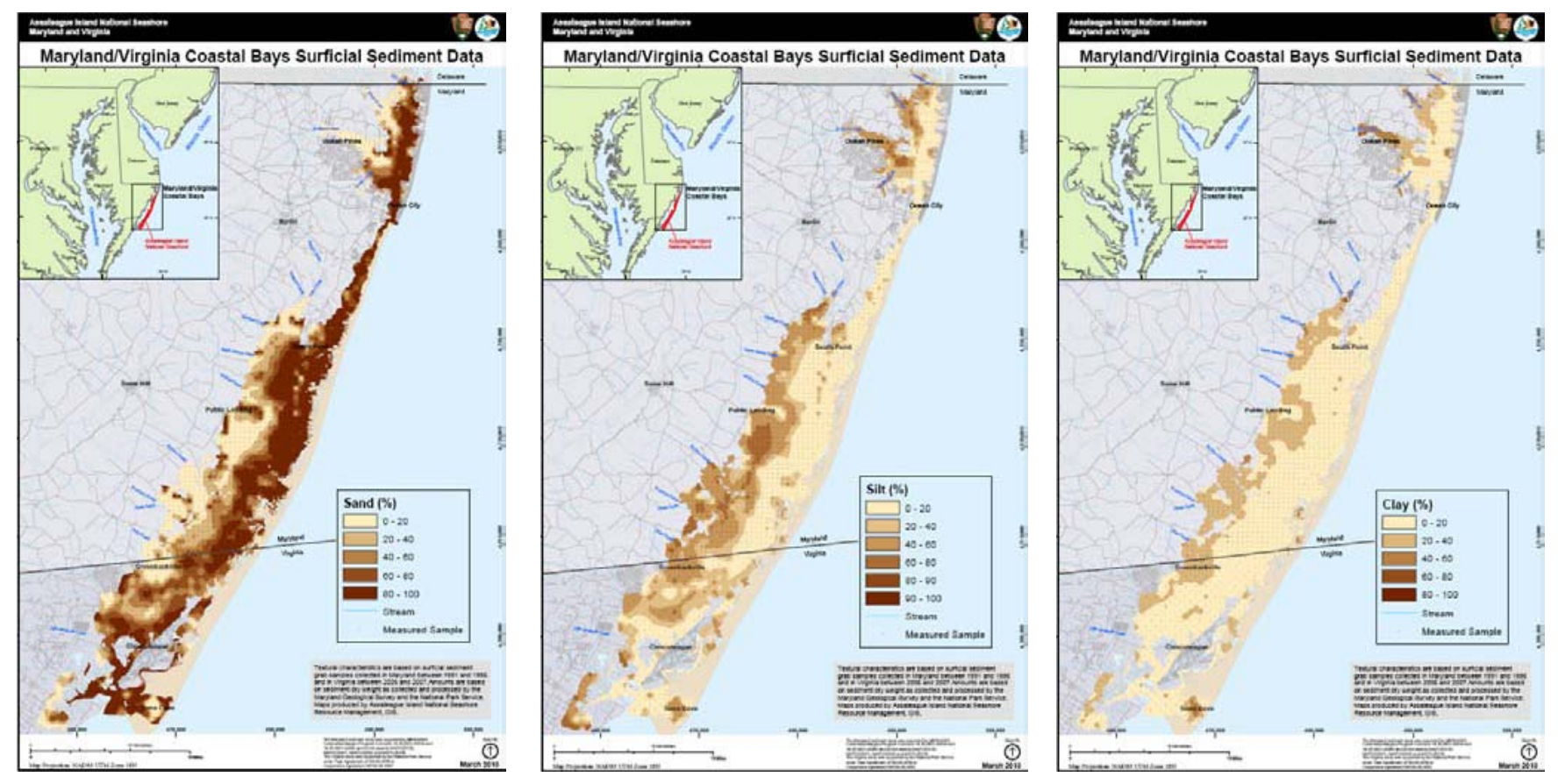

Figure 8. Maryland coastal bays and Virginia coastal bays surficial substrate maps showing percentages of sand, silt, and clay in the Chincoteague Bay (maps courtesy of ASIS Natural Resource Management GIS). 


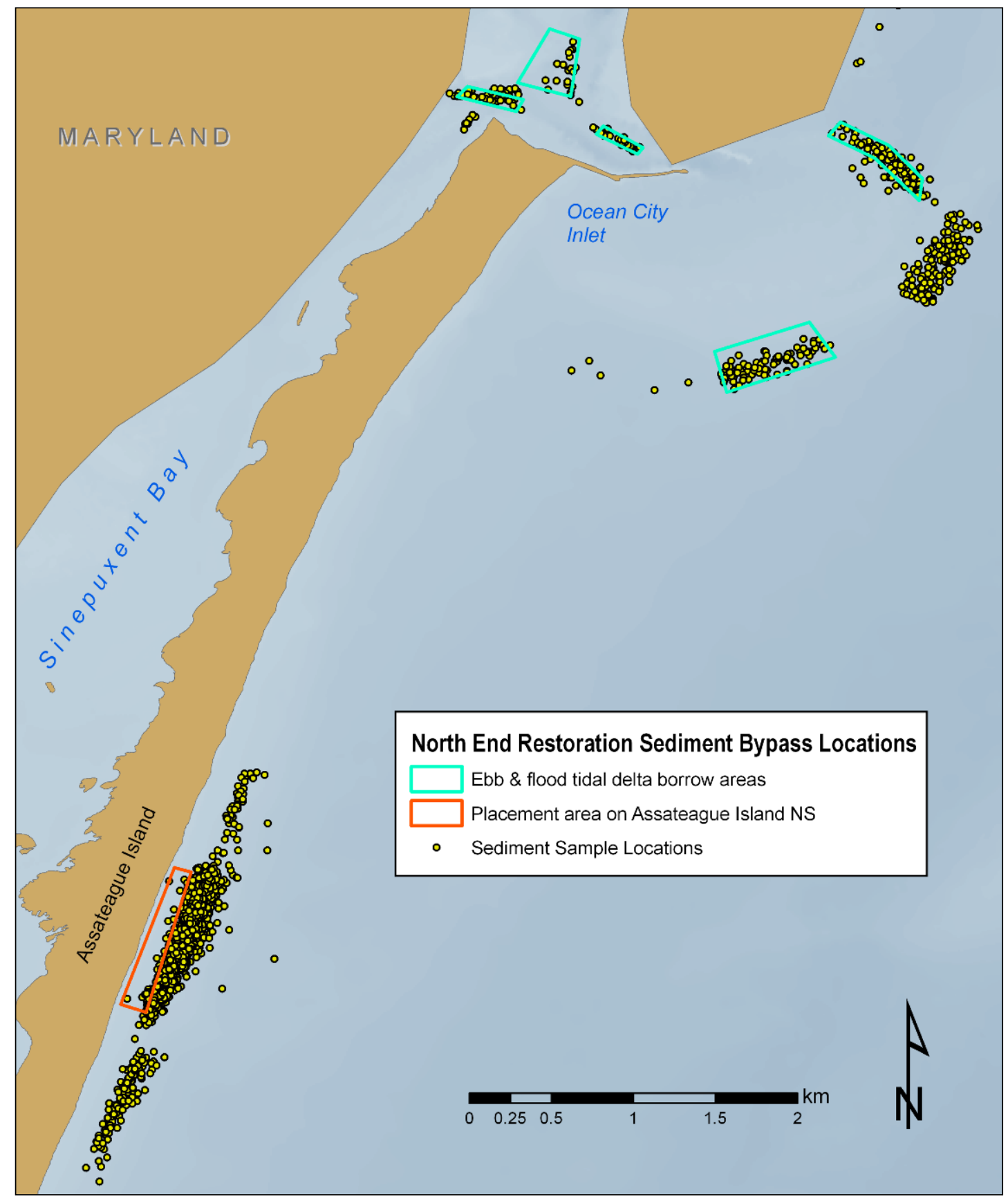

Figure 9. USACE north end restoration sediment borrow and placement areas and sediment sample sites.

\section{Lidar Surveys}

13. Experimental Advanced Airborne Research Lidar (EAARL) coastal topography is a collaborative effort between the U.S. Geological Survey (USGS), NASA, and the NPS. The EAARL system employs a green-wavelength (532-nanometer) raster-scanning laser able to penetrate water depths of up to 1.5 Secchi depths. The 3-kilohertz $(\mathrm{kHz})$ sampling rate records surface return times, which are then converted using the Airborne Lidar Processing System (ALPS) developed by the USGS and 
NASA. Processing yields a dense $\mathrm{x}, \mathrm{y}, \mathrm{z}$ point dataset with 1-m horizontal accuracy and $\pm 15 \mathrm{~cm}$ vertical accuracy for the "first return" surface (Nayegandhi and others, 2009). A "bare earth" surface can be extracted by processing and filtering the data for last-return elevations, resulting in a seamless topobathymetric elevation dataset. EAARL topography for Assateague Island was acquired in 2004 and 2008. Coverage extends along the entire island from shore to shore, except for the southernmost bay side shoreline at Tom's Cove in 2004. Products include GeoTIFF and PDF images of 2-km by 2-km tiles with 2-m resolution, and the imagery was clipped to the extent of usable data (1 Secchi depth). Subaqueous features are visible in the back-barrier nearshore to depths up to $2 \mathrm{~m}$, but usable data were not available for the ocean-side nearshore zone (Brock and others, 2007; Bonisteel and others, 2009a; Bonisteel and others, 2009b) (fig. 10).

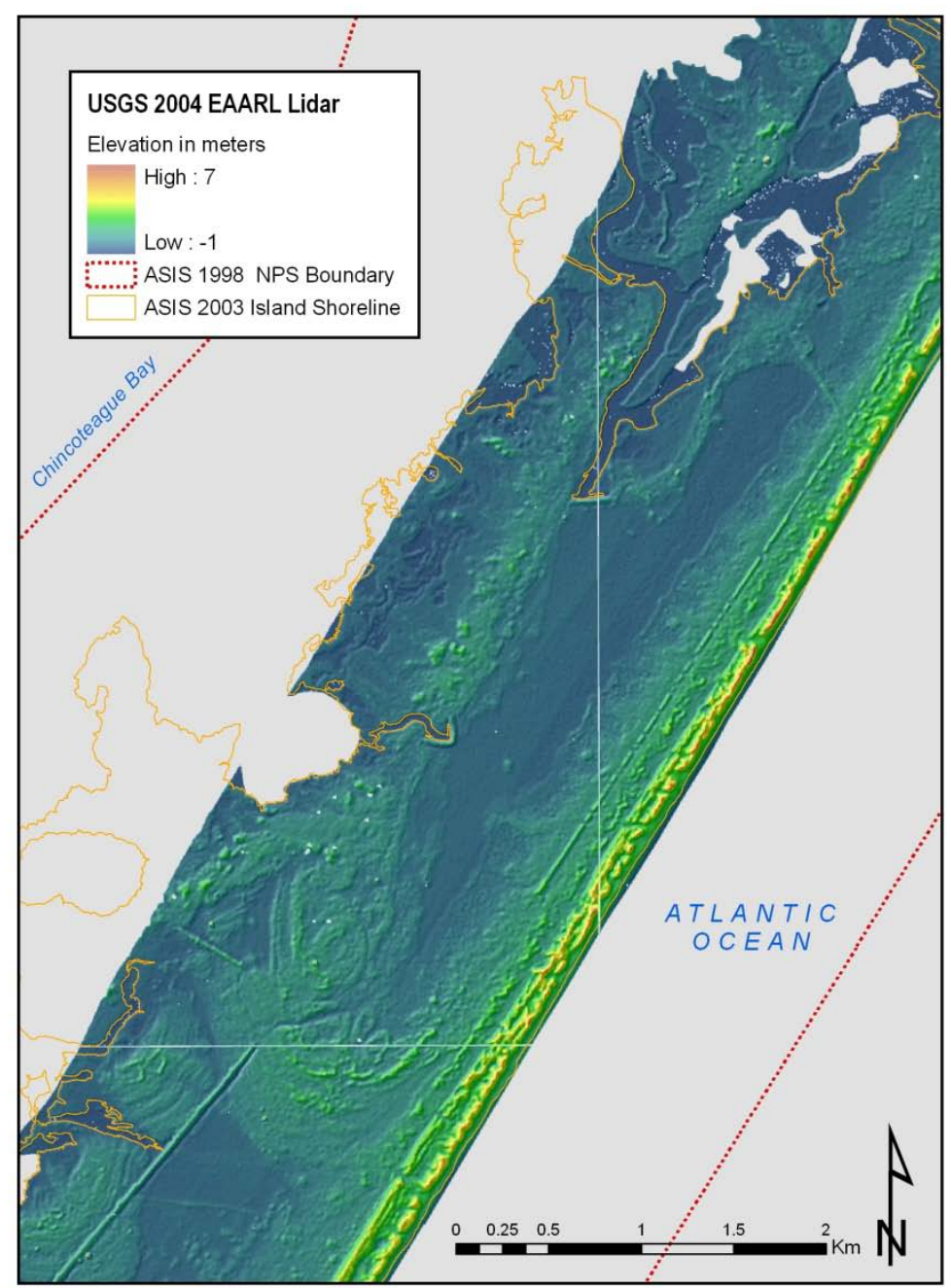

Figure 10. Close-up of NASA-USGS Experimental Advanced Airborne Research Lidar (EAARL) imagery.

14. DEM of Assateague Island, including Chincoteague Bay and the ocean-side area-A 1/9 arc-second $(\sim 3 \mathrm{~m})$ resolution mosaic of the 2008 EAARL topobathymetry, Maryland and Virginia coastal bays 
bathymetry, and the ocean-side NOAA-NOS hydrographic surveys was produced by the USGS Earth Resources Observation and Science (EROS) Center (fig. 11).

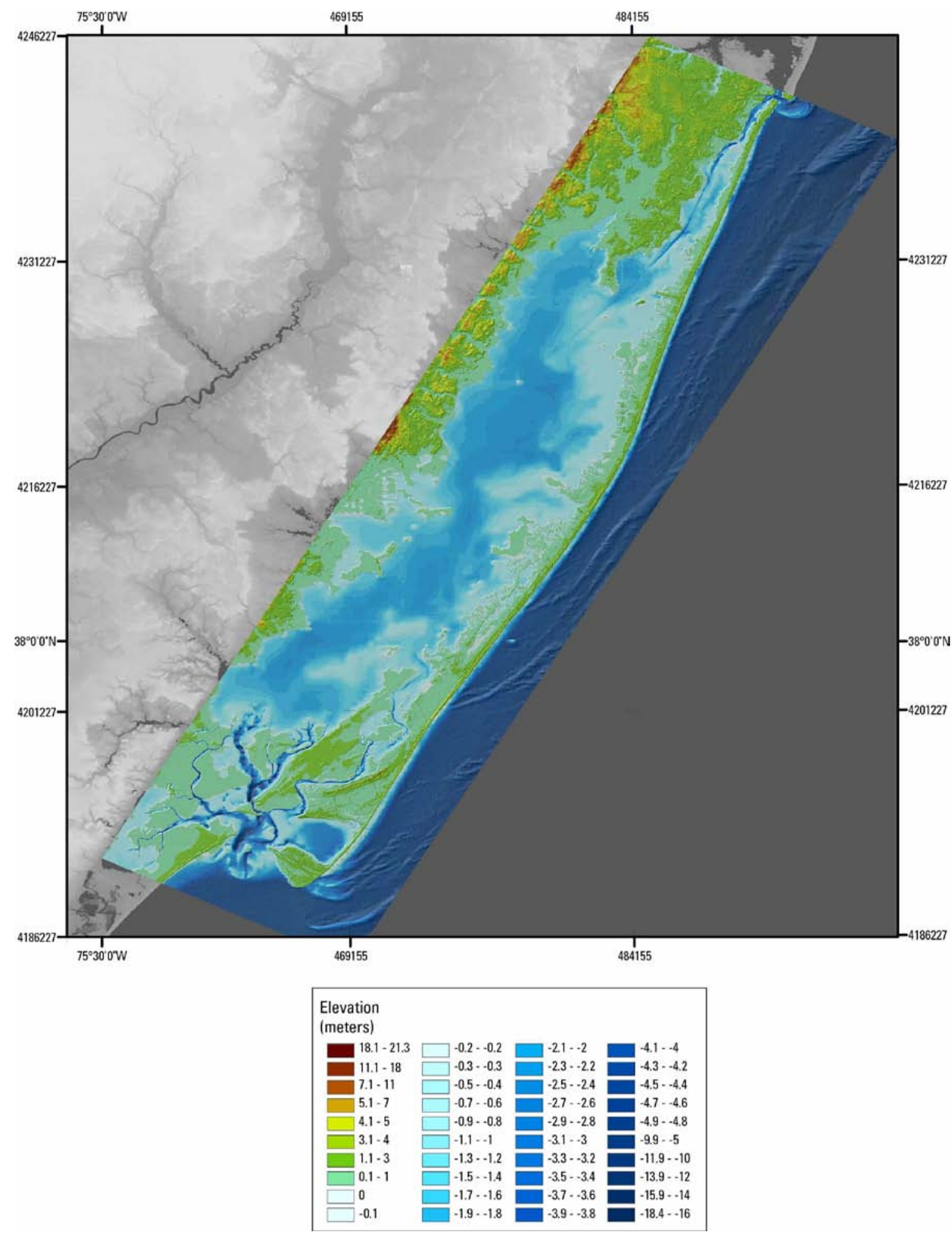

Figure 11. USGS Earth Resources Observation and Science (EROS) Center Assateague lidar topobathymetry. 
15. NASA Airborne Topographic Mapper II (ATM II) lidar data were acquired under the NOAAUSGS-NASA collaborative Airborne Lidar Assessment of Coastal Erosion (ALACE) Project. A swath along the length of the island from the ocean-side shoreline to $\sim 300 \mathrm{~m}$ to $\sim 800 \mathrm{~m}$ landward was flown repeatedly from 1996 to 1998 and in 2000. Three flights were made in 1998 to assess the effects of an unusually severe winter storm season that year. Horizontal accuracy is $\pm 0.8 \mathrm{~m}$, and vertical accuracy is \pm 15 to $20 \mathrm{~cm}$. The processed grids have a 3-m resolution. No benthic features are visible, but this imagery is useful for deriving shoreline positions (fig. 12).

16. Maryland (Worcester County) lidar data from 2002 were acquired by the MD DNR to support coastal erosion studies and Federal Emergency Management Agency (FEMA) floodplain mapping. These data cover only from the Virginia-Maryland border to the north end of the island but extend the entire width of the island. Submerged features can be identified in the back barrier. Data are provided in ASCII grid format with 3-m resolution (Maryland Department of Natural Resources, 2005) (fig. 12).

17. USACE Joint Airborne Lidar Bathymetry Technical Center of Expertise (JALBTCX) lidar data from 2005 were acquired with the Compact Hydrographic Airborne Rapid Total Survey (CHARTS) system equipped with a SHOALS 1000T sensor under the Coastal Mapping Program. Coverage consists of a swath along the southern $33 \mathrm{~km}$ of the island, 700 to $800 \mathrm{~m}$ from the seaward shoreline to the back barrier. Data are provided in ASCII grid format (3-m by 3-m resolution). Horizontal accuracy for this dataset is $\pm 0.75 \mathrm{~m}$, and vertical accuracy is $0.20 \mathrm{~m}$. No benthic features are visible, but this imagery is useful for deriving shoreline positions (fig. 12). 


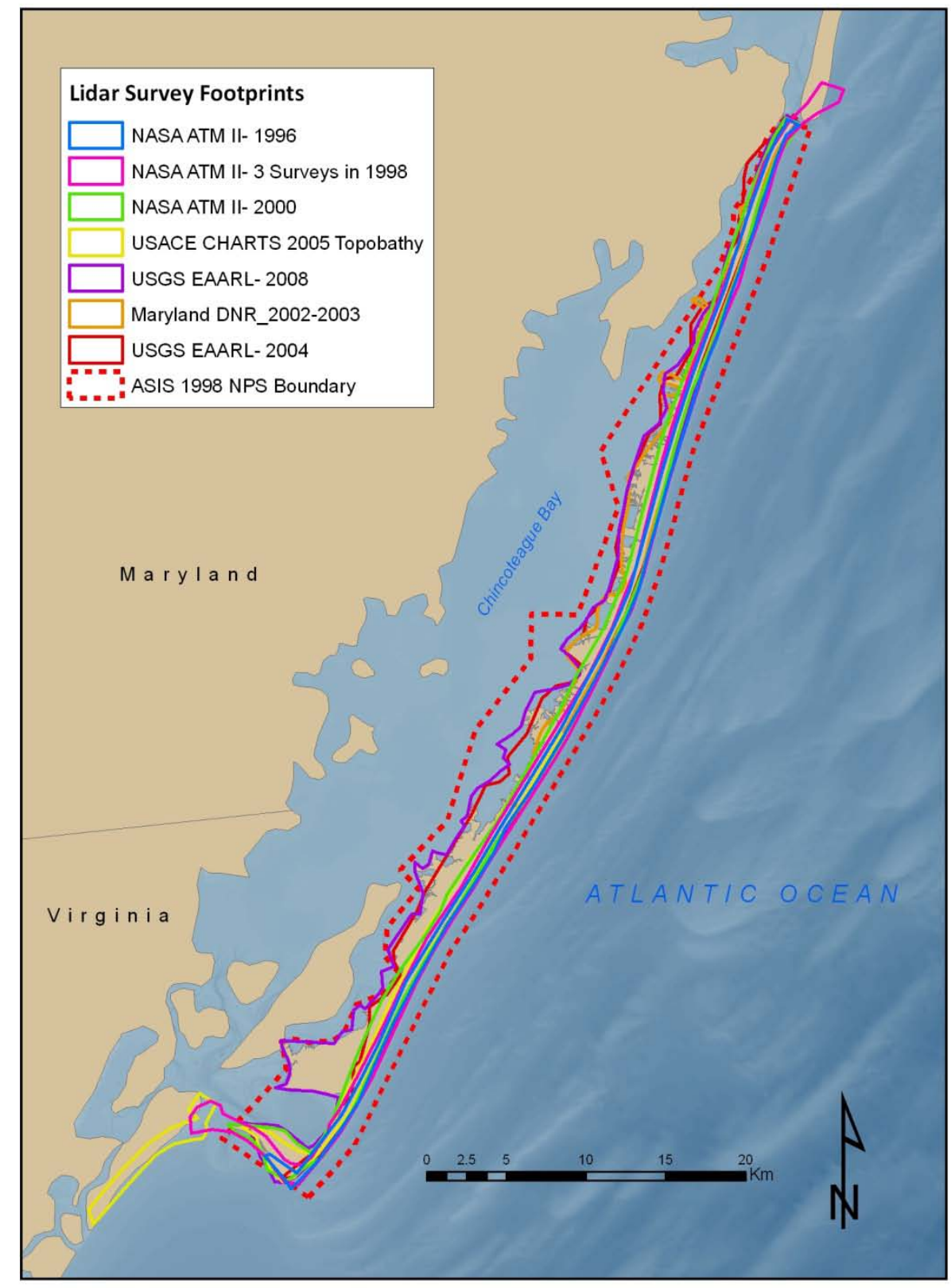

Figure 12. Footprints of lidar surveys at ASIS.

\section{Aerial Imagery}

Aerial imagery may be useful in deriving and enhancing shoreline positions and in identifying submerged features and habitat extents where water clarity is adequate:

18. U.S. Department of Agriculture (USDA) Digital Ortho Quarter Quad (DOQQ) imagery for Worcester County, Md., is available with the following specifications: 
- National Agriculture Imagery Program (NAIP) natural color, 1-m or 2-m spatial resolution images from 2005-2007 and 2009, and

- National Aerial Photography Program (NAPP) black and white or color infrared (CIR), 1:40,000 spatial resolution from 1989, 1994, and 2000.

19. Aerial photography of the Maryland developed zone was taken during lidar flights in 1993 and 1999 (1-m spatial resolution) with excellent nearshore visibility.

20. Satellite imagery is available from two sources:

- NASA-USGS Earth Observer 1 (EO-1) Advanced Land Imager (ALI) 2008 complete island coverage, multi-spectral imagery, $10-\mathrm{m}$ spatial resolution, with visible subaqueous bedforms and suspended sediment (fig. 13), and

- $\quad$ Satellite Pour l'Observation de la Terre (SPOT) 4 medium resolution (20 m) from 1998. 


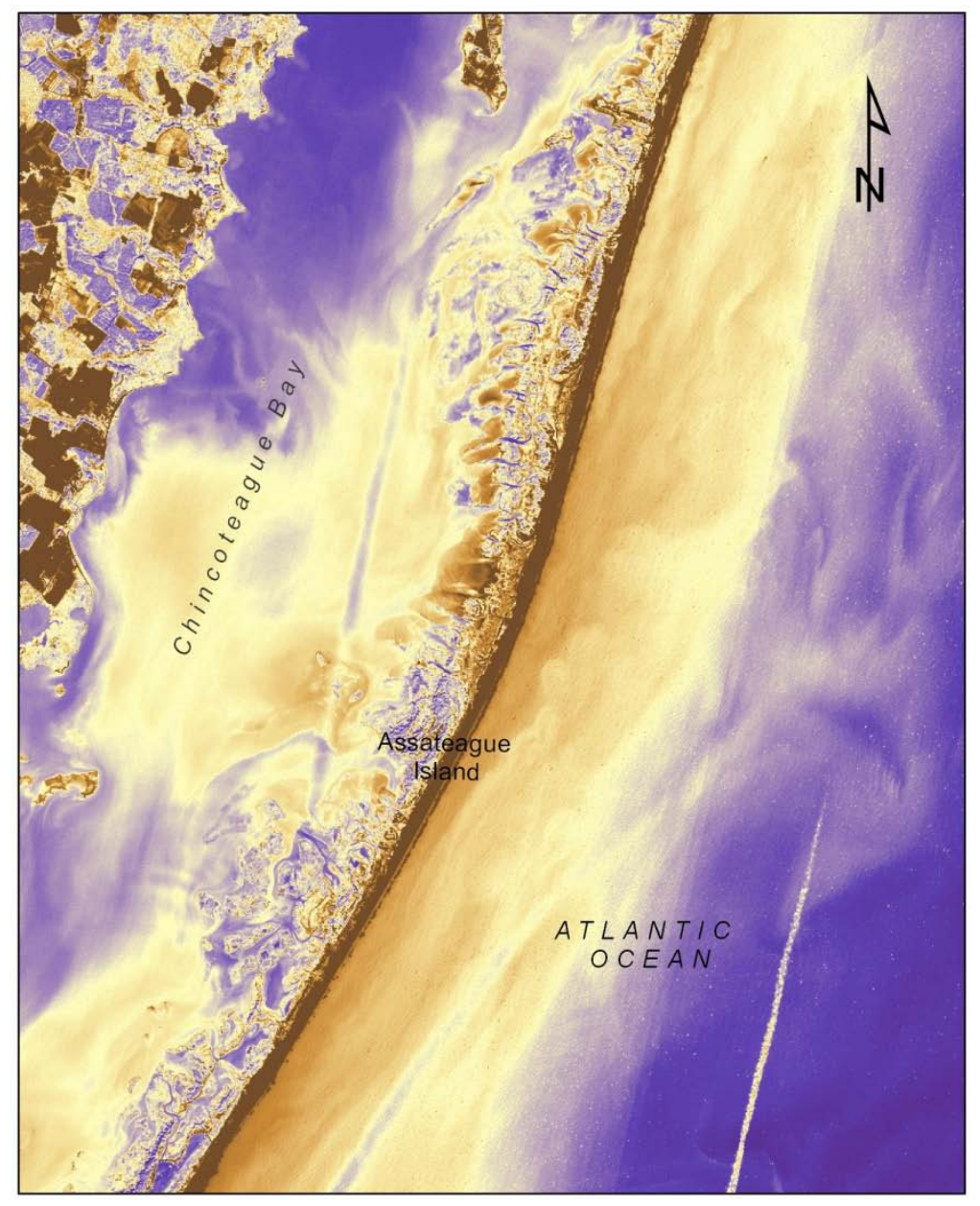

Figure 13. NASA-USGS Earth Observer 1 (EO-1) Advanced Land Imager (ALI) imagery of Assateague Island, 2008 with visible subaqueous bedforms and suspended sediment.

\section{Biological Cover Mapping}

21. Virginia Institute of Marine Sciences (VIMS) submerged aquatic vegetation (SAV) maps and GIS polygons indicating location and density of seagrass in Chincoteague and Sinepuxent Bays were derived from analysis of aerial photography for 1986, 1987, 1989-2004, and 2006-2009 (fig. 14). 


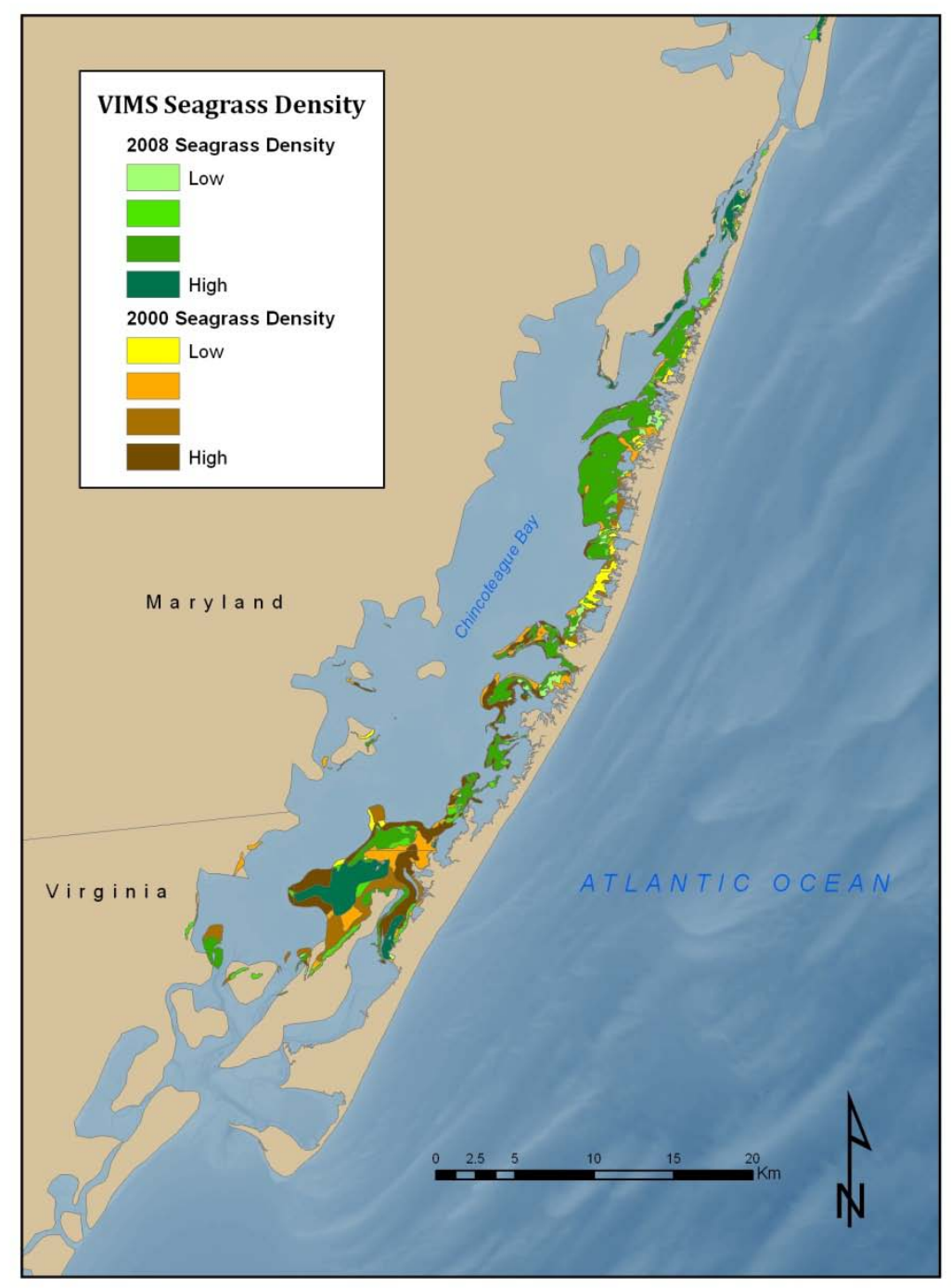

Figure 14. Virginia Institute of Marine Sciences (VIMS) 2008 seagrass bed locations and density overlain on 2000 seagrass beds.

Table 1. Assateague Island National Seashore (ASIS) GIS datasets and imagery (corresponding to numbered paragraphs above).

[Acronyms are listed in Appendix A]

\begin{tabular}{llcll}
\hline & Description & Dates & Source & URL/Point of Contact \\
\hline 1 & $\begin{array}{l}\text { Historic shoreline } \\
\text { positions }\end{array}$ & $1849-1989$ & MGS & http://www.mgs.md.gov/coastal/maps/schangevect.html \\
\hline 2 & $\begin{array}{l}\text { Digital shoreline } \\
\text { positions }\end{array}$ & $1972-2005$ & $\begin{array}{l}\text { NPS Data } \\
\text { Store }\end{array}$ & http://science.nature.nps.gov/nrdata/datastore \\
\hline $\begin{array}{l}\text { ASIS coastline and } \\
\text { jurisdictional } \\
\text { boundaries of } \\
\text { management } \\
\text { agencies }\end{array}$ & 2003-2005 & $\begin{array}{l}\text { NPS Data } \\
\text { Store }\end{array}$ & http://science.nature.nps.gov/nrdata/datastore \\
\hline
\end{tabular}




\begin{tabular}{|c|c|c|c|c|}
\hline & Description & Dates & Source & URL/Point of Contact \\
\hline 3 & $\begin{array}{l}1998 \text { ASIS NPS } \\
\text { boundary }\end{array}$ & 1998 & $\begin{array}{l}\text { NPS Data } \\
\text { Store }\end{array}$ & http://science.nature.nps.gov/nrdata/datastore \\
\hline 4 & $\begin{array}{l}\text { GPS shoreline } \\
\text { positions }\end{array}$ & 1995-2010 & $\begin{array}{l}\text { NPS ASIS } \\
\text { upon request }\end{array}$ & Courtney Schupp, NPS-ASIS: Courtney_Schupp@nps.gov \\
\hline 5 & $\begin{array}{l}\text { NOAA NGDC } \\
\text { DEM of Ocean } \\
\text { City, MD }\end{array}$ & 1880-2007 & $\begin{array}{l}\text { NOAA } \\
\text { NGDC }\end{array}$ & http://www.ngdc.noaa.gov/mgg/inundation/ \\
\hline 6 & $\begin{array}{l}\text { ASIS north end } \\
\text { bathymetry }\end{array}$ & 2004-2009 & $\begin{array}{l}\text { NPS ASIS } \\
\text { upon request }\end{array}$ & Courtney Schupp, NPS-ASIS: Courtney_Schupp@nps.gov \\
\hline 7 & $\begin{array}{l}\text { USACE nearshore } \\
\text { profile elevations }\end{array}$ & 2003-2009 & $\begin{array}{l}\text { NPS ASIS } \\
\text { upon request }\end{array}$ & Courtney Schupp, NPS-ASIS: Courtney_Schupp@nps.gov \\
\hline 8 & $\begin{array}{l}\text { Maryland coastal } \\
\text { bays bathymetry } \\
\text { grid }\end{array}$ & 2000-2003 & $\begin{array}{l}\text { NPS ASIS } \\
\text { upon request }\end{array}$ & Courtney Schupp, NPS-ASIS: Courtney_Schupp@nps.gov \\
\hline 9 & $\begin{array}{l}\text { Virginia coastal } \\
\text { bays bathymetry } \\
\text { grid }\end{array}$ & 2006 & $\begin{array}{l}\text { NPS Data } \\
\text { Store }\end{array}$ & http://science.nature.nps.gov/nrdata/datastore \\
\hline 10 & $\begin{array}{l}\text { Maryland coastal } \\
\text { bays surficial } \\
\text { sediment }\end{array}$ & 1991-1997 & $\begin{array}{l}\text { NPS Data } \\
\text { Store }\end{array}$ & http://science.nature.nps.gov/nrdata/datastore \\
\hline 11 & $\begin{array}{l}\text { Virginia coastal } \\
\text { bays surficial } \\
\text { sediment } \\
\end{array}$ & 2006-2007 & $\begin{array}{l}\text { NPS Data } \\
\text { Store }\end{array}$ & http://science.nature.nps.gov/nrdata/datastore \\
\hline 12 & $\begin{array}{l}\text { North end } \\
\text { restoration } \\
\text { sediment bypass } \\
\text { sites } \\
\end{array}$ & 2005-2009 & $\begin{array}{l}\text { NPS Data } \\
\text { Store }\end{array}$ & http://science.nature.nps.gov/nrdata/datastore \\
\hline 13 & $\begin{array}{l}\text { USGS } 2004 \\
\text { EAARL lidar- } \\
\text { ASIS }\end{array}$ & 2004 & $\begin{array}{l}\text { USGS Open- } \\
\text { File Report } \\
\text { 2007-1176 } \\
\end{array}$ & http://pubs.usgs.gov/of/2007/1176/ \\
\hline 13 & $\begin{array}{l}\text { USGS } 2008 \\
\text { EAARL lidar- } \\
\text { ASIS }\end{array}$ & 2008 & $\begin{array}{l}\text { USGS Data } \\
\text { Series } 446\end{array}$ & http://pubs.usgs.gov/ds/447/ \\
\hline 14 & $\begin{array}{l}\text { USGS EROS } \\
\text { Assateague Island } \\
\text { DEM }\end{array}$ & 2008 & & \\
\hline 15 & $\begin{array}{l}\text { NASA ATM II } \\
\text { lidar }\end{array}$ & 1996-2000 & $\begin{array}{l}\text { NOAA } \\
\text { Coastal } \\
\text { Services } \\
\text { Center }\end{array}$ & http://www.csc.noaa.gov/digitalcoast/data/coastallidar/index.html \\
\hline 16 & $\begin{array}{l}2002 \text { Maryland } \\
\text { (Worcester County) } \\
\text { lidar }\end{array}$ & 2002 & MD DNR & http://csc.noaa.gov/ldart \\
\hline 17 & $\begin{array}{l}\text { USACE } 2005 \\
\text { CHARTS lidar }\end{array}$ & 2005 & $\begin{array}{l}\text { USACE } \\
\text { JALBTCX }\end{array}$ & http://shoals.sam.usace.army.mil/ \\
\hline 18 & $\begin{array}{l}\text { USDA DOQQ } \\
\text { imagery }\end{array}$ & 1989-2009 & USDA APFO & http://www.fsa.usda.gov/FSA/apfo \\
\hline 19 & $\begin{array}{l}\text { ASIS aerial } \\
\text { photography taken } \\
\text { during lidar flights }\end{array}$ & 1993, 1999 & $\begin{array}{l}\text { NPS Data } \\
\text { Store }\end{array}$ & http://science.nature.nps.gov/nrdata/datastore \\
\hline 20 & $\begin{array}{l}\text { NASA-USGS EO-1 } \\
\text { ALI satellite } \\
\text { imagery }\end{array}$ & 2008 & NASA/USGS & http://glovis.usgs.gov/ImgViewer \\
\hline
\end{tabular}




\begin{tabular}{|c|c|c|c|c|}
\hline & Description & Dates & Source & URL/Point of Contact \\
\hline 20 & $\begin{array}{l}\text { SPOT satellite } \\
\text { imagery }\end{array}$ & 1998 & $\begin{array}{l}\text { USGS EROS } \\
\text { Data } \\
\text { Center/Spot } \\
\text { Image } \\
\text { Corporation }\end{array}$ & http://edcsns17.cr.usgs.gov/EarthExplorer/ \\
\hline 21 & $\begin{array}{l}\text { VIMS SAV (bay } \\
\text { side only) }\end{array}$ & 1986-2009 & VIMS & http://web.vims.edu/bio/sav/index.html \\
\hline
\end{tabular}

\section{High-Priority Benthic Inventory Needs}

The following high-priority needs were outlined by the ASIS park resource management staff in response to the draft Submerged Data Product Needs Assessment form:

- High-resolution bathymetry for the ocean side of ASIS, preferably at greater than 10-m horizontal resolution, to characterize sediment transport dynamics and identify micro- and mesohabitats.

- Geoform (GFC) mapping throughout the park.

- Benthic cover maps (CMECS biological cover component [BCC] and surface geology component [SGC]) of the ocean side of ASIS, and ground-truthed BCC maps of Chincoteague Bay are essential for inventorying biological communities. Charter boat captains suggest that hardgrounds are likely inside the ASIS boundary, and drop camera photos provide evidence of soft corals on hardgrounds or gravel outcrops. Such hardgrounds could potentially support diverse benthic communities that need to be inventoried to begin proper management.

\section{Summary}

Evaluation of existing data shows percentages of area mapped for bathymetry $(Z)=60$ percent, biologic cover $(B)=52$ percent, geoform $(G)=0$ percent, and surface geology $(S)=52$ percent, so that:

$$
I_{o}(\mathrm{ASIS})=0.25(60 \%+52 \%+0 \%+52 \%)=41 \%
$$

The present mapped status for ASIS, therefore, is about 41 percent complete, primarily due to the absence of geoform mapping throughout the park and to large data gaps on the ocean side. However, a 2-year comprehensive benthic habitat surveying and mapping project for the ocean side of ASIS has been funded and is currently in the planning stage. The project is jointly managed by the NPS and MD DNR and will result in an NPS Natural Resource Series Report. The planned surveying will cover the entire ocean-side extent of ASIS. Objectives to complete are identification of surficial sediment characteristics using sonar-based remote sensing and grab samples, production of a high-resolution bathymetric map,mapping of shallow subsurface features, and classification and mapping of substrate and habitats using the CMECS classification scheme (Courtney Schupp, NPS ASIS written commun., 2010). The SBMP requires a final mapping report after park mapping is completed. Further assessment of the benthic mapping needs for ASIS should be conducted following completion of the upcoming project. 


\section{Pilot Gap Analysis: Channel Islands National Park}

\section{Regional Setting and Geography}

Located off the west coast of southern California in the Pacific Ocean, Channel Islands National Park (CHIS) has jurisdiction over $497 \mathrm{~km}^{2}$ of submerged resources and encompasses five islands: Anacapa, Santa Cruz, Santa Rosa, San Miguel, and Santa Barbara (fig. 15). The CHIS jurisdictional boundary extends $2 \mathrm{~km}$ from the shoreline of each island across a depth range of 0 to $165 \mathrm{~m}$, with $>40$ percent of the submerged acreage shallower than $20 \mathrm{~m}$ (fig. 16), making it easily accessible to divers. The park's submerged acres lie entirely within the Channel Islands National Marine Sanctuary (CINMS), administered by NOAA, and contains several Marine Reserves (MRs) and Marine Conservation Areas (MCAs).

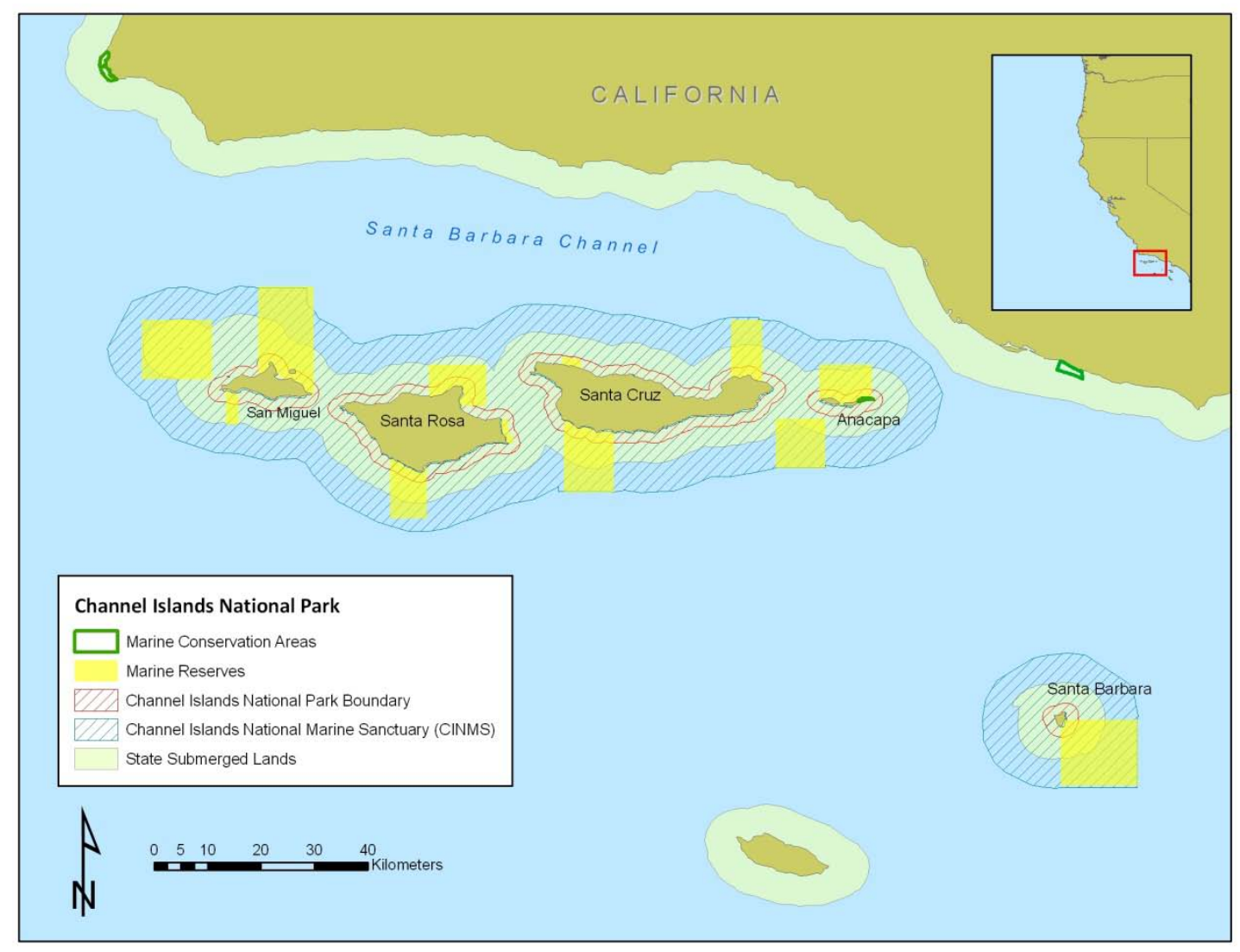

Figure 15. Location map of the Channel Islands National Park (CINP) showing the NPS and CINMS boundaries, Marine Reserves, and Marine Conservation Areas. 


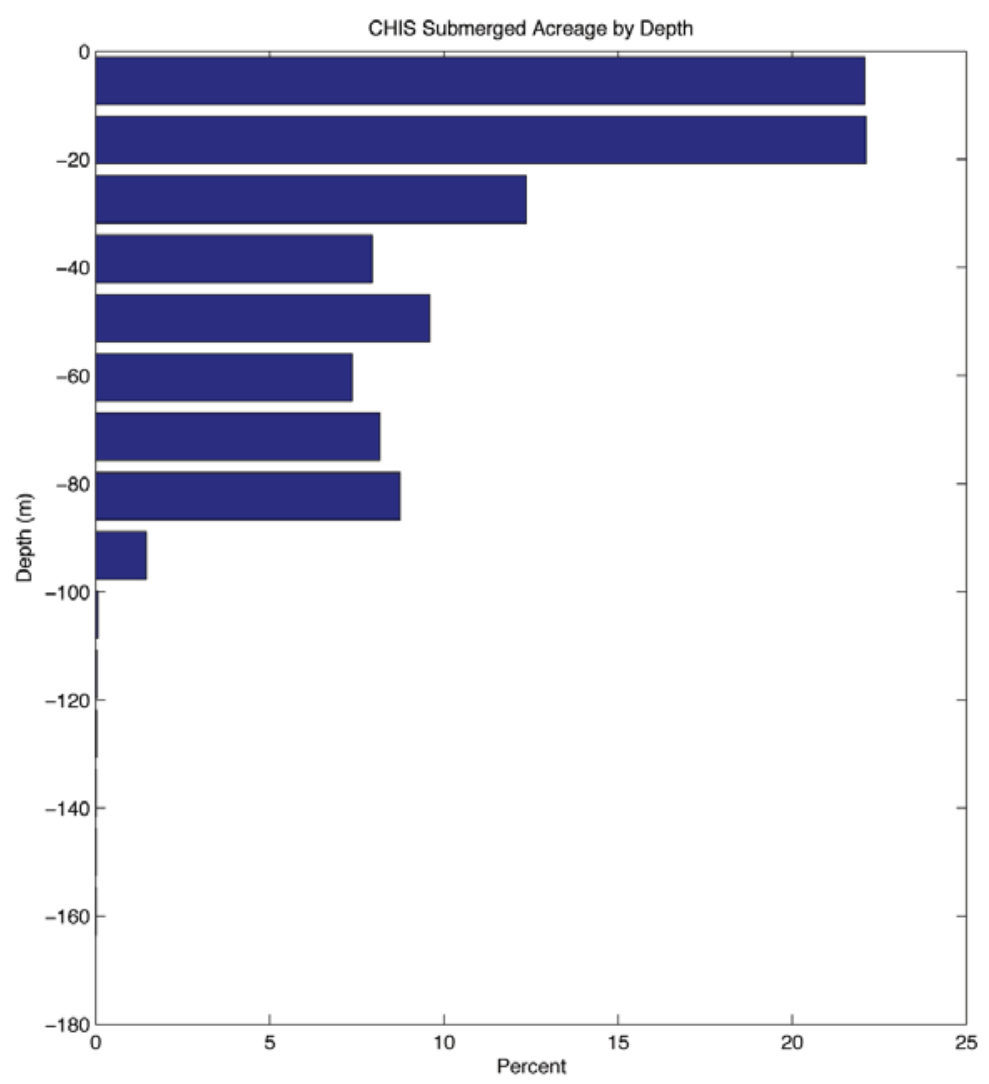

Figure 16. Histogram of Channel Islands National Park (CHIS) mapped submerged acreage by depth.

The environment around CHIS is entirely oceanic and supports a diverse range of habitats. The islands are located near the boundary between two oceanographic water column provinces: the Oregonian and the Californian. Geologically, the islands strike east-west across a large anticline that provides various submerged rock and gravel outcrop features in the benthic environment. Isolation from the mainland fosters endemism, preserving unique terrestrial habitats and species.

\section{Environmental Concerns}

\section{Endangered Marine Species}

Several commercial and recreational species such as the California spiny lobster (Panulirus interruptus) and the red abalone (Halitosis rufescens) occupy the Channel Islands' waters for all or part of their life cycle. Overfishing, leading to dangerously depleted populations, necessitated establishment of the CINMS, Marine Reserves, and Conservation Areas, where fishing and harvesting are restricted. The main management priority within these areas is to preserve biodiversity and sustain healthy populations of aquatic life (California Department of Fish and Game, 2008).

\section{Kelp Forests}

Giant kelp (Macrocystis pyrifera) grows in water depths of as much as $30 \mathrm{~m}$, forming “forests” throughout the Channel Islands and creating habitat for hundreds of other species (Schiff and others, 
2000). Kelp benefits from the mixing of cold and warm currents as well as from the nutrient-rich upwelling that occurs throughout the park.

\section{Rocky Intertidal Zone}

Tidal pools at CHIS contain a wide range of biodiversity, even by comparison to the California mainland. The diurnal tidal cycle and rocky substrate support an exceptional variety of organisms in a relatively narrow geographic range, often within only a few lateral meters. This zone is simultaneously one of the easiest and most complicated zones requiring benthic maps. The proximal location to the shoreline and the twice-daily subaerial exposure contribute to the ease of mapping; however, high water energy and temporal variability of the water column make it temporally challenging.

\section{Available Benthic Data and Map Products}

CHIS data and product sources described in paragraphs 1-7 below are listed in table 2 (at the end of this section).

\section{Bathymetry and Shoreline Data}

A DEM of Santa Barbara, Calif., from the NOAA NGDC with a $1 / 3$ arc-second $(\sim 10 \mathrm{~m})$ interpolated bathymetry grid was generated to support tsunami inundation modeling. Within the CHIS boundary, the interpolated DEM grid incorporates data from NOS hydrographic surveys (1930-2005) (fig. 17) and California State University-Monterey Bay (CSUMB) multibeam acoustic swath bathymetry (2003-2008). The bathymetry map extends from the mainland north of the islands to approximately $15 \mathrm{~km}$ south of Santa Rosa Island, excluding Santa Barbara Island (fig. 18) (Carignan and others, 2009). 


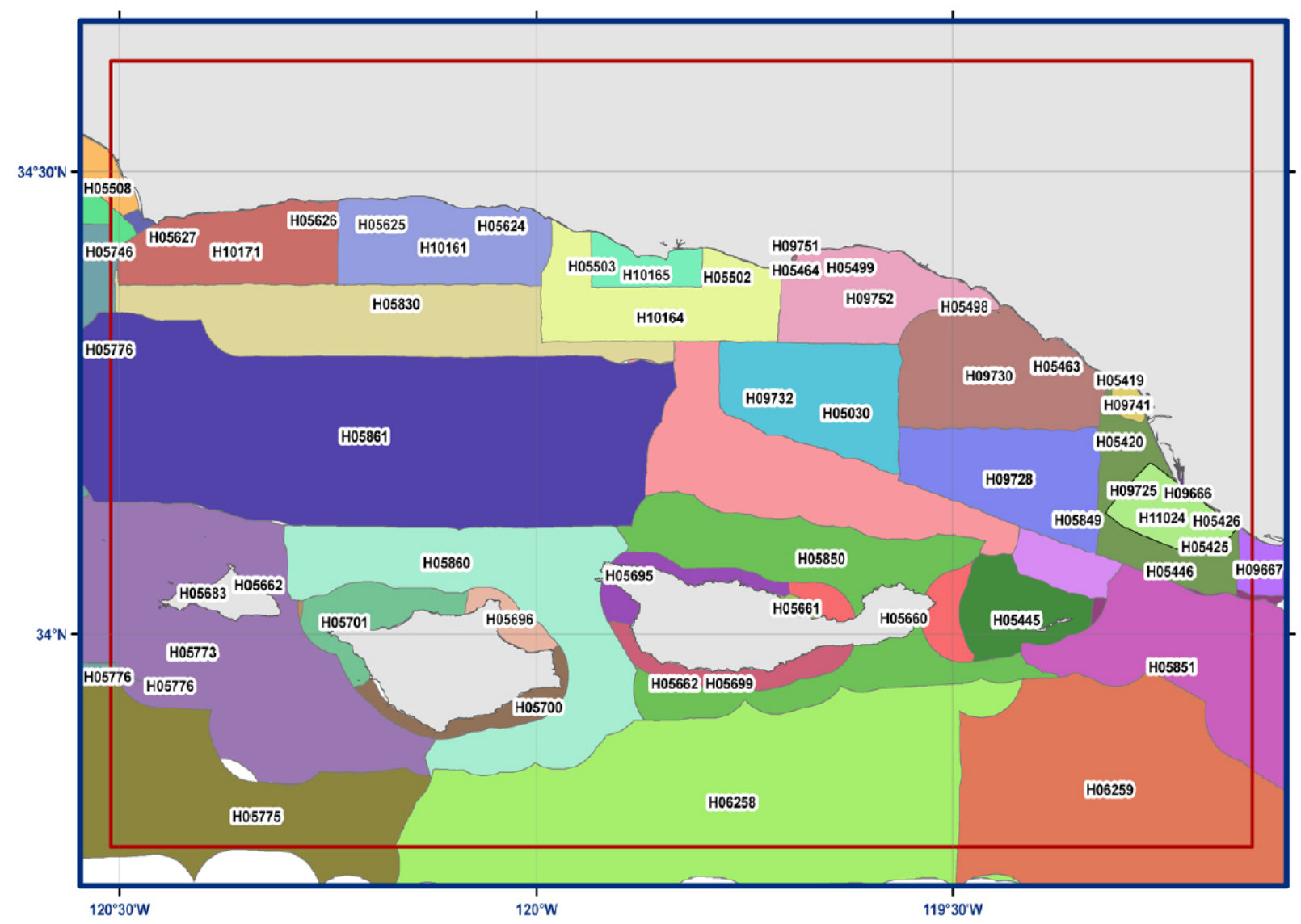

Figure 17. NOS hydrographic survey coverage used in the NOAA NGDC digital elevation model (DEM) of Santa Barbara. 


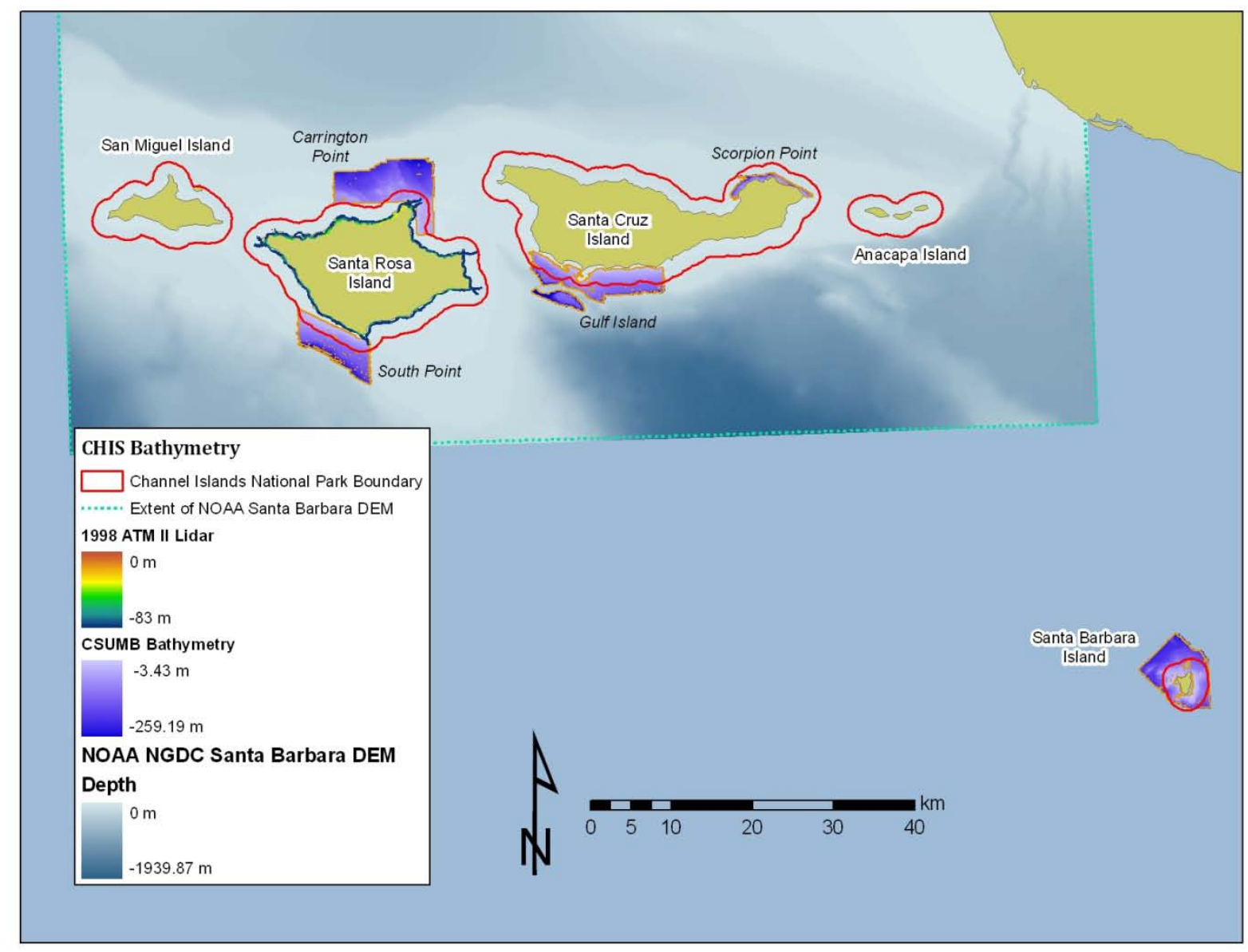

Figure 18. Channel Islands National Park (CHIS) bathymetry datasets: NOAA NGDC digital elevation model (DEM) of Santa Barbara and California State University-Monterey Bay (CSUMB) bathymetry survey sites.

The CSUMB bathymetry has high spatial resolution but is limited in extent. Individual bathymetry DEMs for Carrington Point and South Point on Santa Rosa Island, Gull Island, Scorpion Point on Santa Cruz Island, and Santa Barbara Island were acquired using a multibeam acoustic system. The bathymetry DEMs are available in 2-m or 3-m resolution grids (figs. 18, 19).

Airborne Topographic Mapper II (ATM II) lidar was acquired under the NOAA-USGS-NASA collaborative Airborne Lidar Assessment of Coastal Erosion Project in 1997 and 1998 around Santa Barbara Island only. Both surveys have the same footprint and would be useful for deriving shoreline positions rather than bathymetry. Figure 19 shows a close-up of the spring 1998 lidar data with the CSUMB Carrington Point bathymetry grid, illustrating the spatial gap between the two datasets (fig. 19). 


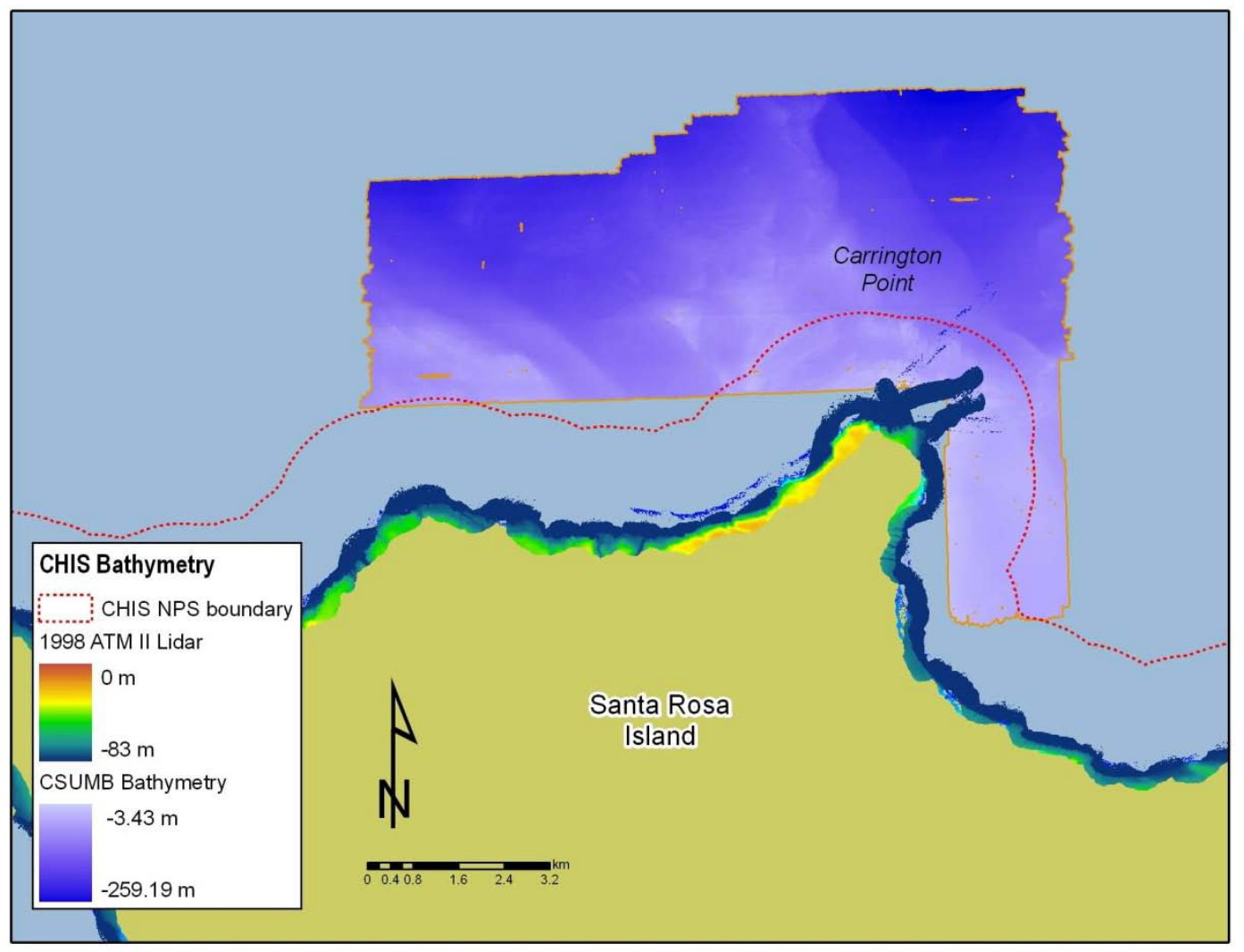

Figure 19. Close-up of ATM II lidar and California State University-Monterey Bay (CSUMB) Carrington Point bathymetry.

\section{USGS Benthic Habitat Data}

Benthic habitat maps exist for the nearshore to offshore areas at the southern side of San Miguel Island, the northern side of Anacapa Island (collected in 1998; Cochrane and others, 2003), southern Anacapa Island, north and south Anacapa Passage, and southeastern Santa Cruz Island (collected in 1999-2000; Cochrane and others, 2005) (fig. 20). Substrate type was interpreted using a textural analysis of the backscatter imagery of sidescan acoustic surveys and classified according to the system of Greene and others (1999) (fig. 21). The data are available in GIS files as follows: ESRI shapefiles (vector) and ArcInfo grids (raster). Trackline spacing within the survey area gave complete overlapping coverage of 1-m resolution imagery that extends beyond the park boundaries. Acoustic data were ground-truthed with photographs and video at scuba and remotely operated vehicle (ROV) sites and with samples of surficial sediment. Approximate survey coverage areas within the park boundaries are

- $\quad$ southern San Miguel Island, surveyed in 1998 ( 20 km2),

- northern Anacapa Island, surveyed in 1998 ( 21 km2),

- $\quad$ southern Anacapa Island, surveyed in 1999 and 2000 ( 22 km2),

- North and South Anacapa Passage, surveyed in 1999 and 2000 ( 10.5 km2), and

- Southeastern Santa Cruz Island, surveyed in 1999 and 2000 ( 49 km2). 


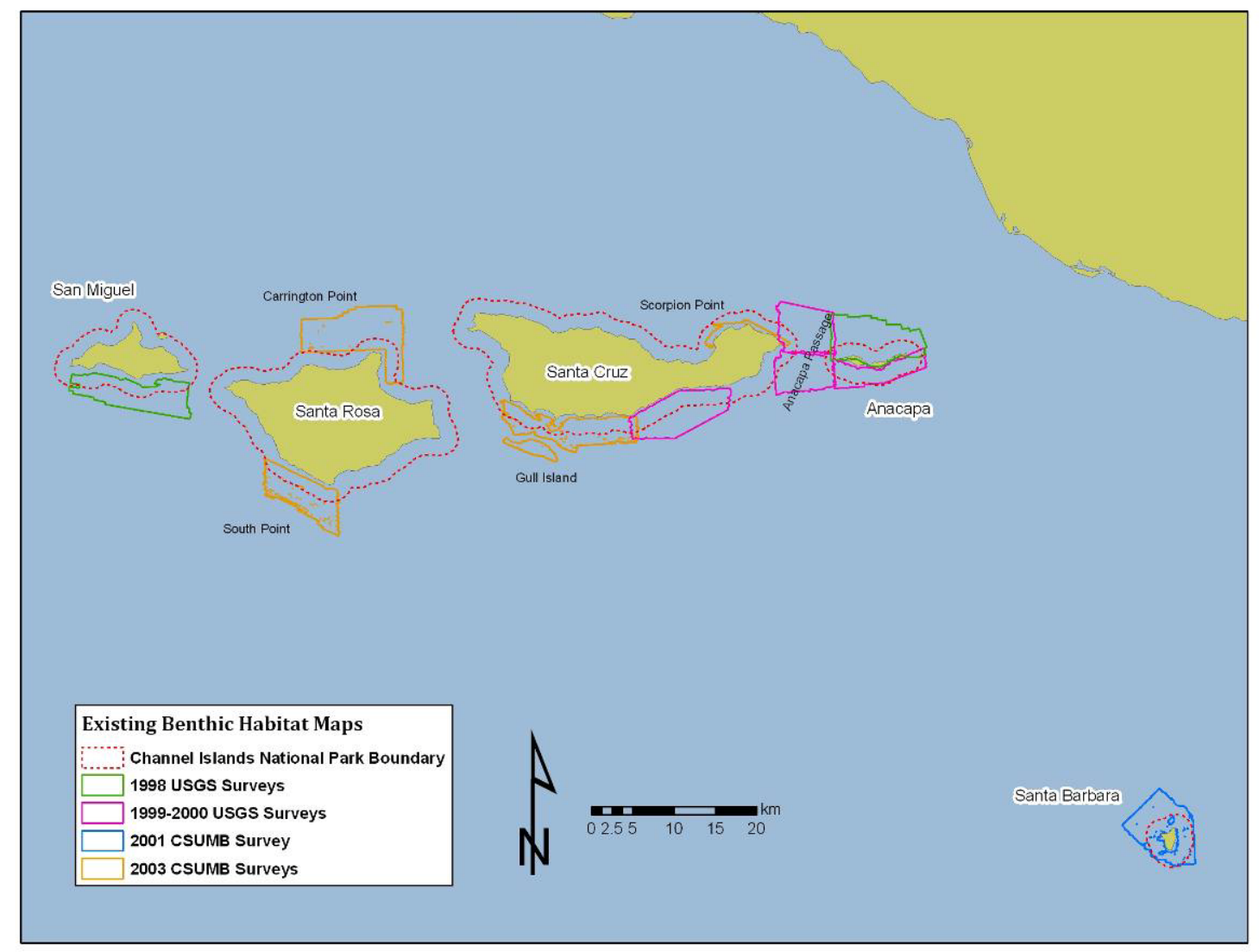

Figure 20. Footprints of existing USGS and California State University-Monterey Bay (CSUMB) benthic habitat maps. 


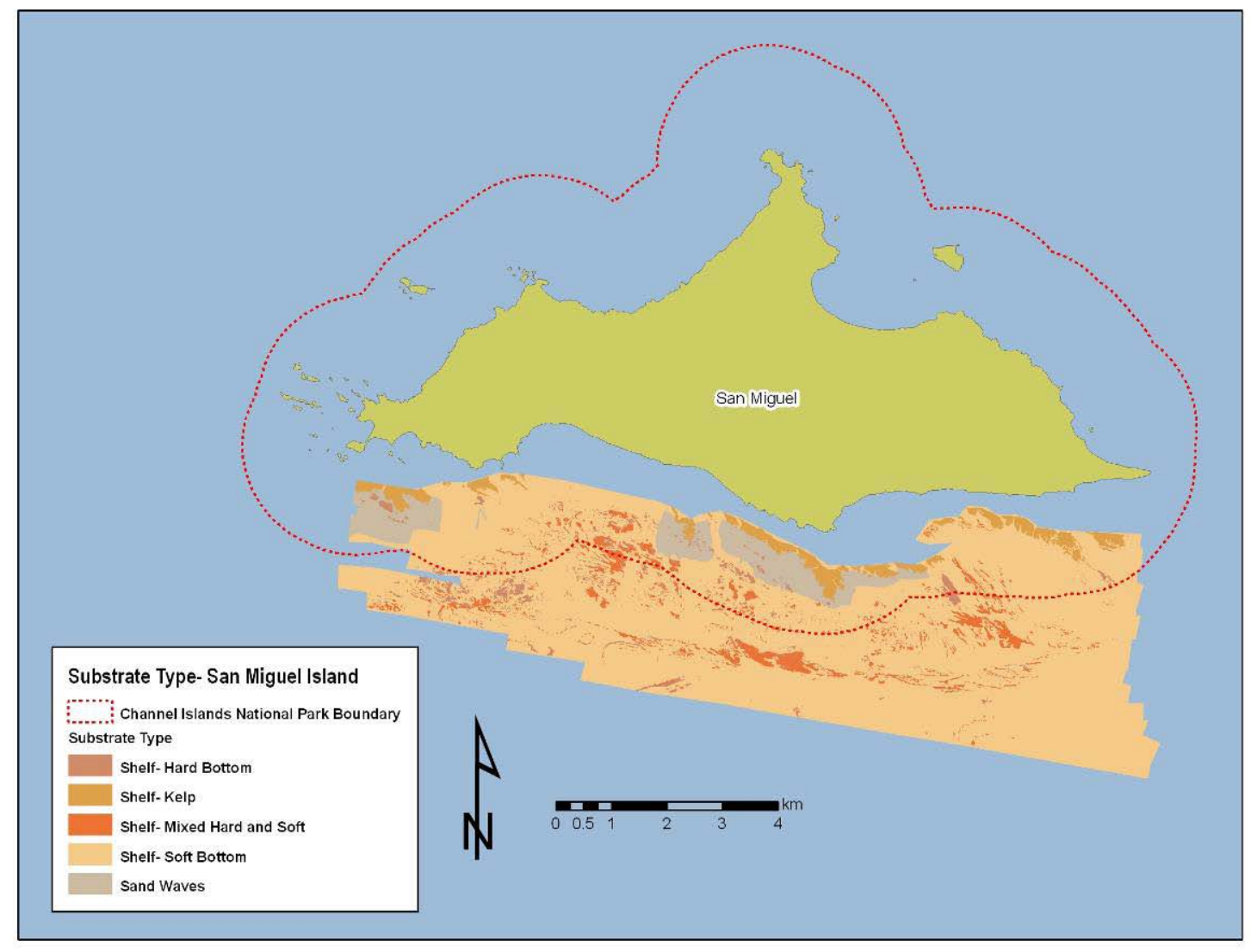

Figure 21. USGS benthic substrate map, San Miguel Island, California (Cochrane and others, 2003).

\section{CSUMB Benthic Habitat Data}

Sidescan sonar imagery was collected concurrently with the multibeam bathymetry (fig. 20). Areas of substrate types and geoforms were identified by rugosity analysis of the bathymetric DEMs and were then overlain and compared with visual inspections of raster grids of the imagery. GIS files were created from the re-examined data and classified using a modified Greene and others (1999) scheme (fig. 22). Approximate survey coverage within park boundaries is

- Santa Barbara Island, surveyed in $2001\left(\sim 23 \mathrm{~km}^{2}\right)$,

- South Point, surveyed in $2003\left(\sim 14 \mathrm{~km}^{2}\right)$,

- Carrington Point, surveyed in $2003\left(\sim 11 \mathrm{~km}^{2}\right)$,

- Scorpion Point, surveyed in $2003\left(\sim 9 \mathrm{~km}^{2}\right)$, and

- Gull Island, surveyed in 2003 ( 27 km2). 


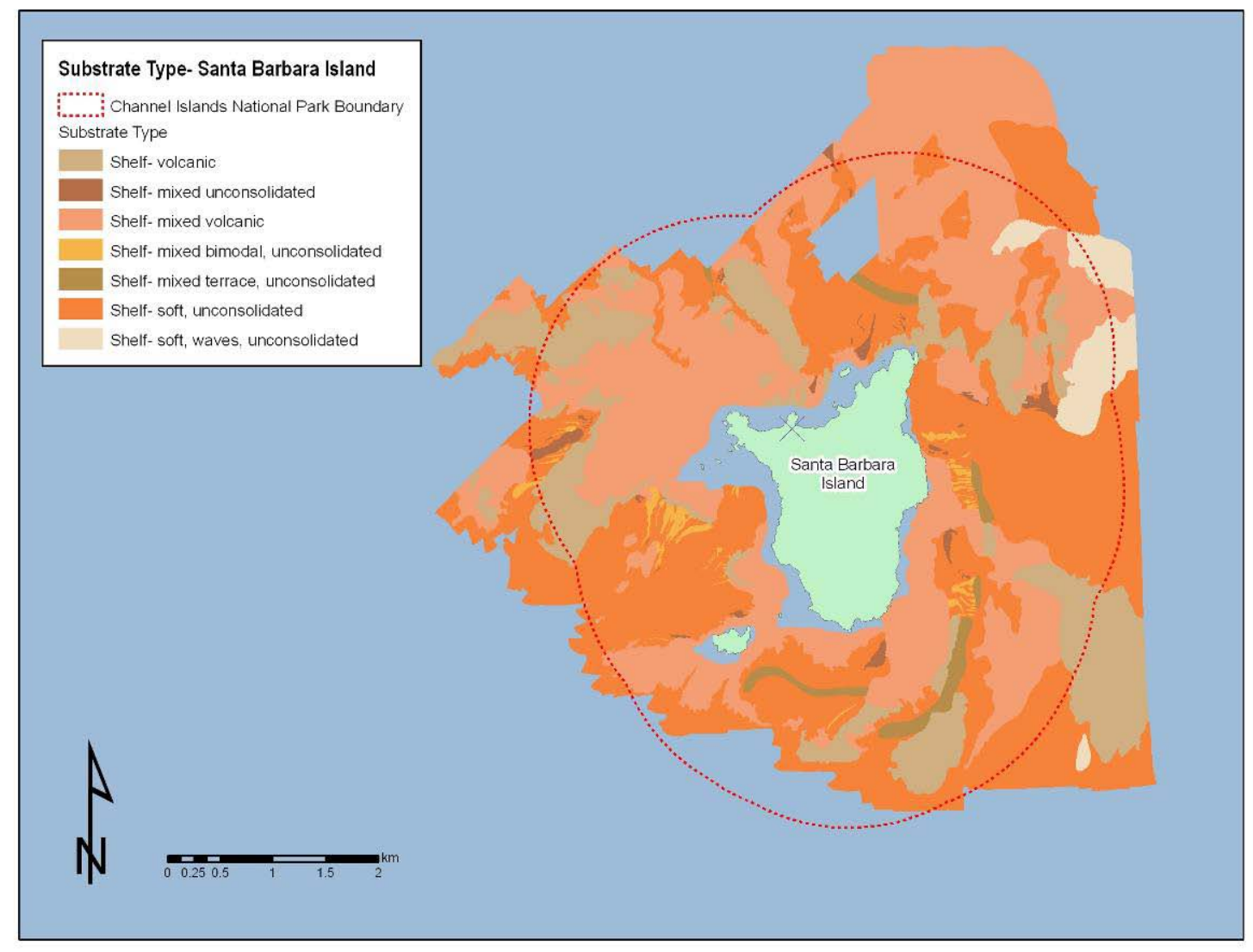

Figure 22. California State University-Monterey Bay (CSUMB) benthic substrate map, Santa Barbara Island, California.

\section{Aerial Imagery}

Several DOQQs are available for the Channel Islands through either the NAIP or USGS aerial photography programs from 1996, 2000, 2002, and 2005. Although water clarity is generally good, sun glint, waves, and water depth hinder visibility. In select areas, however, geoforms and vegetation can be discerned.

\section{Biological Cover Data}

The California Department of Fish and Game (CDFG) maintains kelp management areas around the Channel Islands and conducts regular surveys using aerial color-infrared photography and multispectral digital video to monitor the extent of kelp beds and identify subsurface beds and canopies. Data for the kelp management areas are available from 1989, 1999, 2002-2006, and 2008 (figs. 23, 24). 


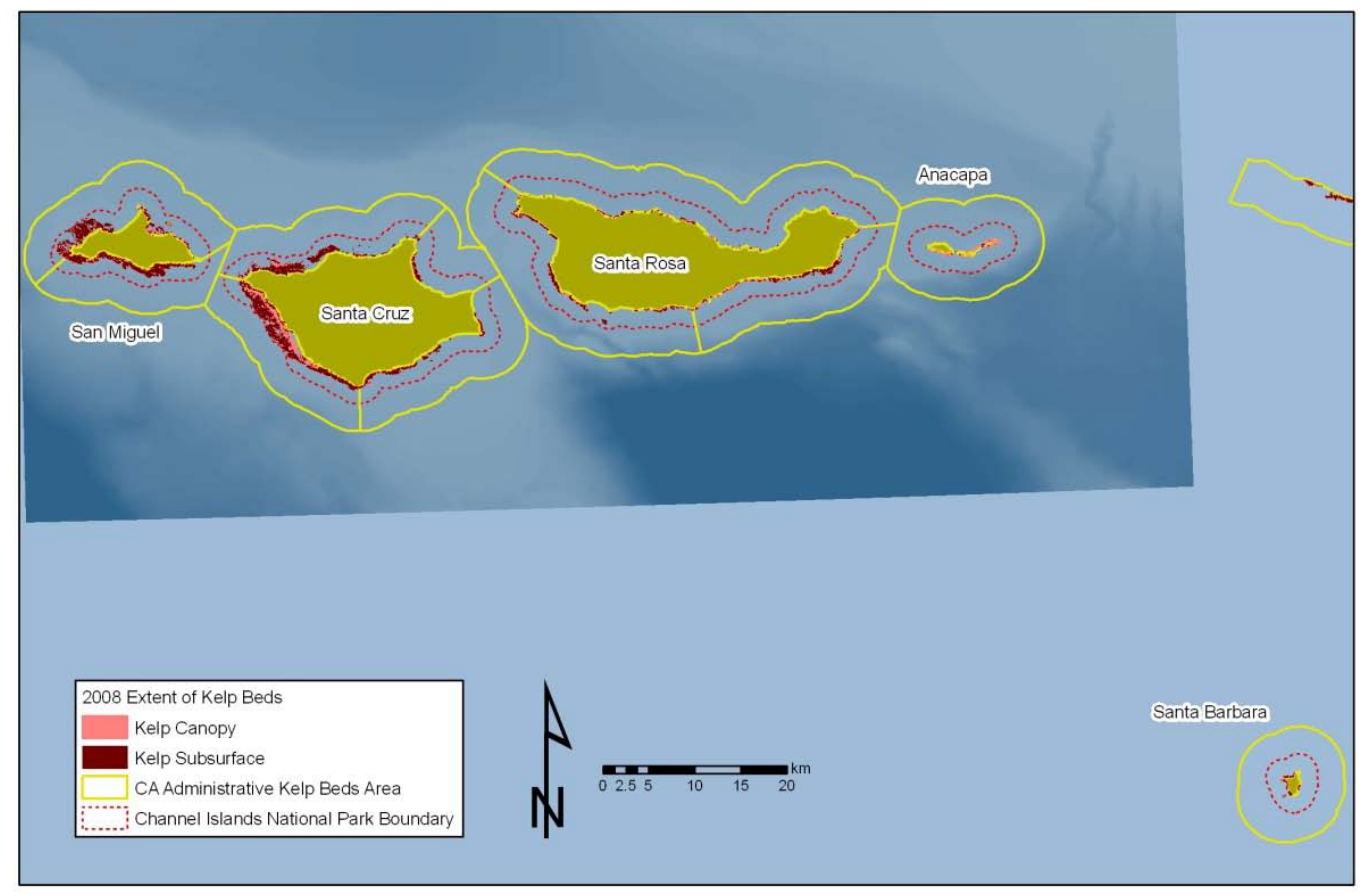

Figure 23. California kelp management areas and 2008 mapped extent of kelp beds surrounding Channel Islands National Park (CHIS). 


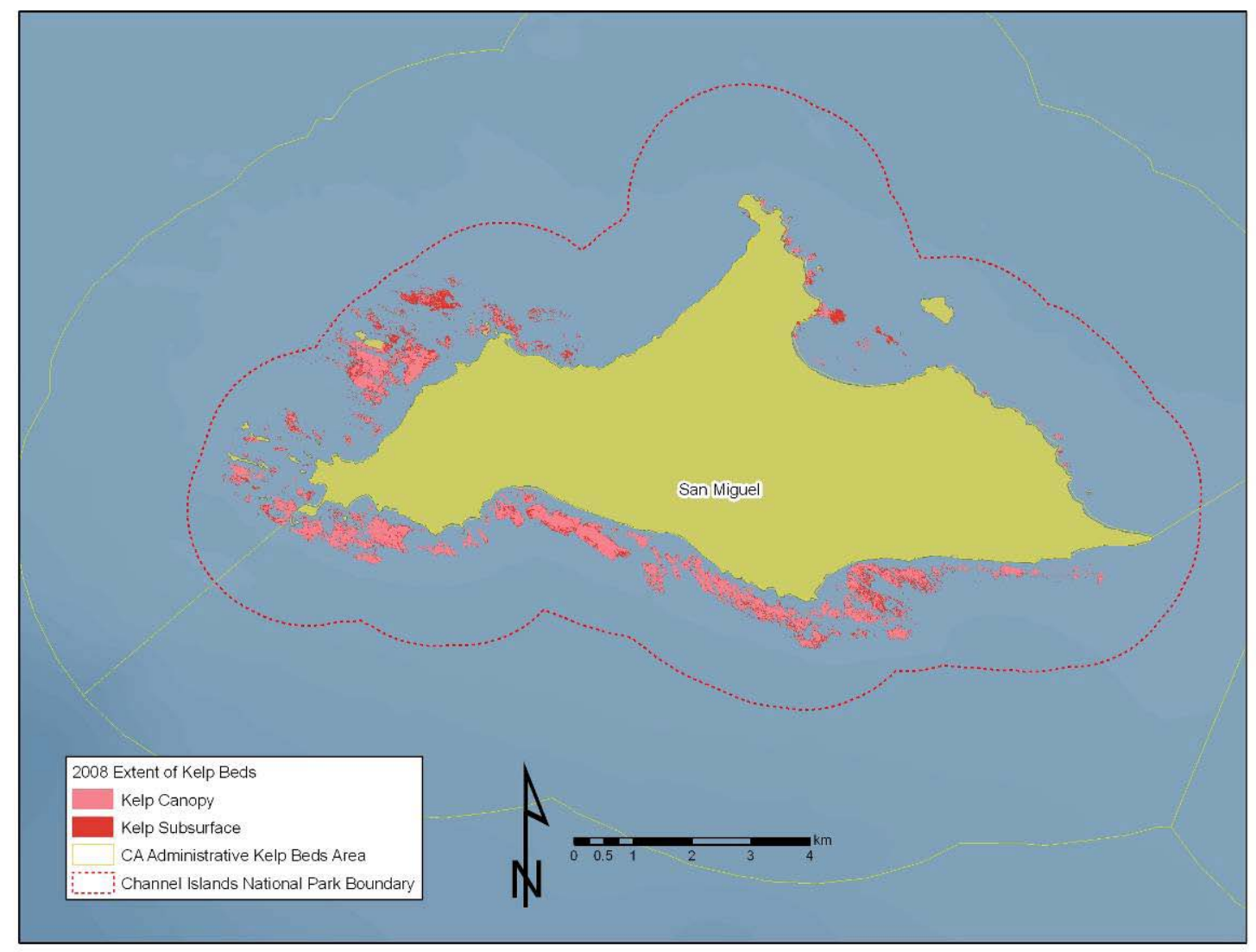

Figure 24. California Department of Fish and Game (CDFG) 2008 kelp bed sites around San Miguel Island, California.

\section{High-Priority Benthic Inventory Needs}

The following benthic data deficits were identified by the CHIS Park Resource Manager as highpriority:

- high-resolution bathymetry around the islands within the park boundary,

- $\quad$ surveying of unmapped areas of the park, including the rocky intertidal zone, and

- production of thematic maps of CMECS biological cover component (BCC), surface geology component (SGC), and geoform component (GFC).

\section{Summary}

Percentages of individual benthic habitat components for CHIS are listed below:

$Z=17$ percent (source: CSUMB bathymetry grids)

$B=95$ percent (source: CDFG kelp bed maps)

$G=42$ percent (source: combined area of USGS and CSUMB benthic habitat maps) 


$$
S=42 \text { percent (source: combined area of USGS and CSUMB benthic habitat maps) }
$$

Benthic mapping status for CHIS is estimated at 49 percent,

Where

$$
I_{o}=0.25(17 \%+95 \%+42 \%+42 \%)=49 \%
$$

Although much of the offshore area has already been mapped, the older data need to be reevaluated to determine validity. Data are lacking for the nearshore environments, which require surveying, analysis, and mapping. Lidar bathymetry data need to be acquired for the remaining islands and be integrated with existing acoustic data in order to provide a seamless, detailed map of the rocky intertidal and nearshore zones out to deeper water to assist in identification of shallow water habitats. Acoustic bathymetry surveys, where data are lacking, should be conducted from the perimeter of the lidar data out to the park boundary.

Since a variety of benthic habitat data of CHIS has been produced using different classification schemes, existing maps need to be cross-checked with CMECS SGC, GFC, and BCC schemes (if possible). Validation by drop camera or towed video surveys will increase confidence in the cross-check with CMECS BCC. For any of the older map products covering areas of potential change, remapping should be considered if the original data are more than 10 years old. It would be beneficial to scientists and managers to have a reference report comparing the existing maps and the converted CMECS maps.

Table 2. Channel Islands National Park (CHIS) GIS datasets and imagery (corresponding to numbered paragraphs above).

[Acronyms are listed in Appendix A]

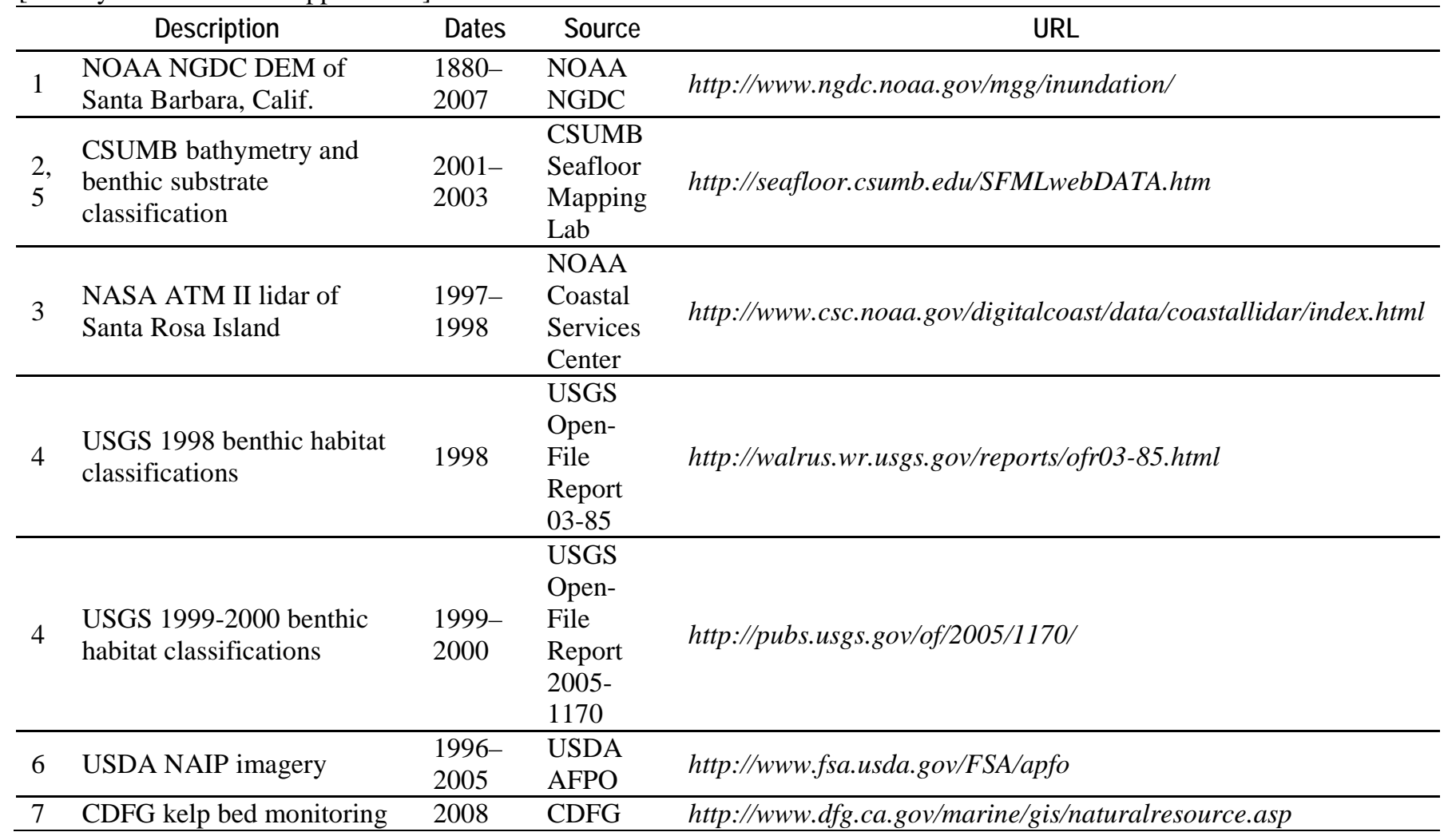




\begin{tabular}{lcll}
\hline \multicolumn{1}{c}{ Description } & Dates & Source & \multicolumn{1}{c}{ URL } \\
\hline \multicolumn{3}{c}{ Administrative and Jurisdictional Boundaries } \\
\hline Channel Islands shorelines & 2001 & $\begin{array}{l}\text { NPS Data } \\
\text { Store }\end{array}$ & http://science.nature.nps.gov/nrdata/datastore \\
\hline CHIS NPS boundary & 2001 & $\begin{array}{l}\text { NPS Data } \\
\text { Store }\end{array}$ & http://science.nature.nps.gov/nrdata/datastore \\
\hline & \multirow{2}{*}{$\begin{array}{l}\text { NOAA } \\
\text { National } \\
\text { CINMS boundary }\end{array}$} & $\begin{array}{l}\text { Marine } \\
\text { Sanctuary } \\
\text { Program }\end{array}$ \\
& 2004 http://sanctuaries.noaa.gov/library/imast_gis.html \\
\hline $\begin{array}{l}\text { California marine regulatory } \\
\text { boundaries }\end{array}$ & 2004 & http://csc-s-maps-q.csc.noaa.gov/legislativeatlas/ \\
\hline
\end{tabular}

\section{Pilot Gap Analysis: Sleeping Bear Dunes National Lakeshore Regional Setting and Geography}

Sleeping Bear Dunes National Lakeshore (SLBE), located on the eastern shores of Lake Michigan, includes $42 \mathrm{~km}^{2}$ of submerged resources. The park boundary completely encircles South Manitou Island and North Manitou Island and includes a stretch along the mainland shore in Leelanau and Benzie Counties, Mich. (fig. 25). SLBE park lakeward boundaries extend $400 \mathrm{~m}$ from the shoreline, and water depths within the boundary range from 0 to $150 \mathrm{~m}$, with most of the acreage shallower than $25 \mathrm{~m}$ (fig. 26). 


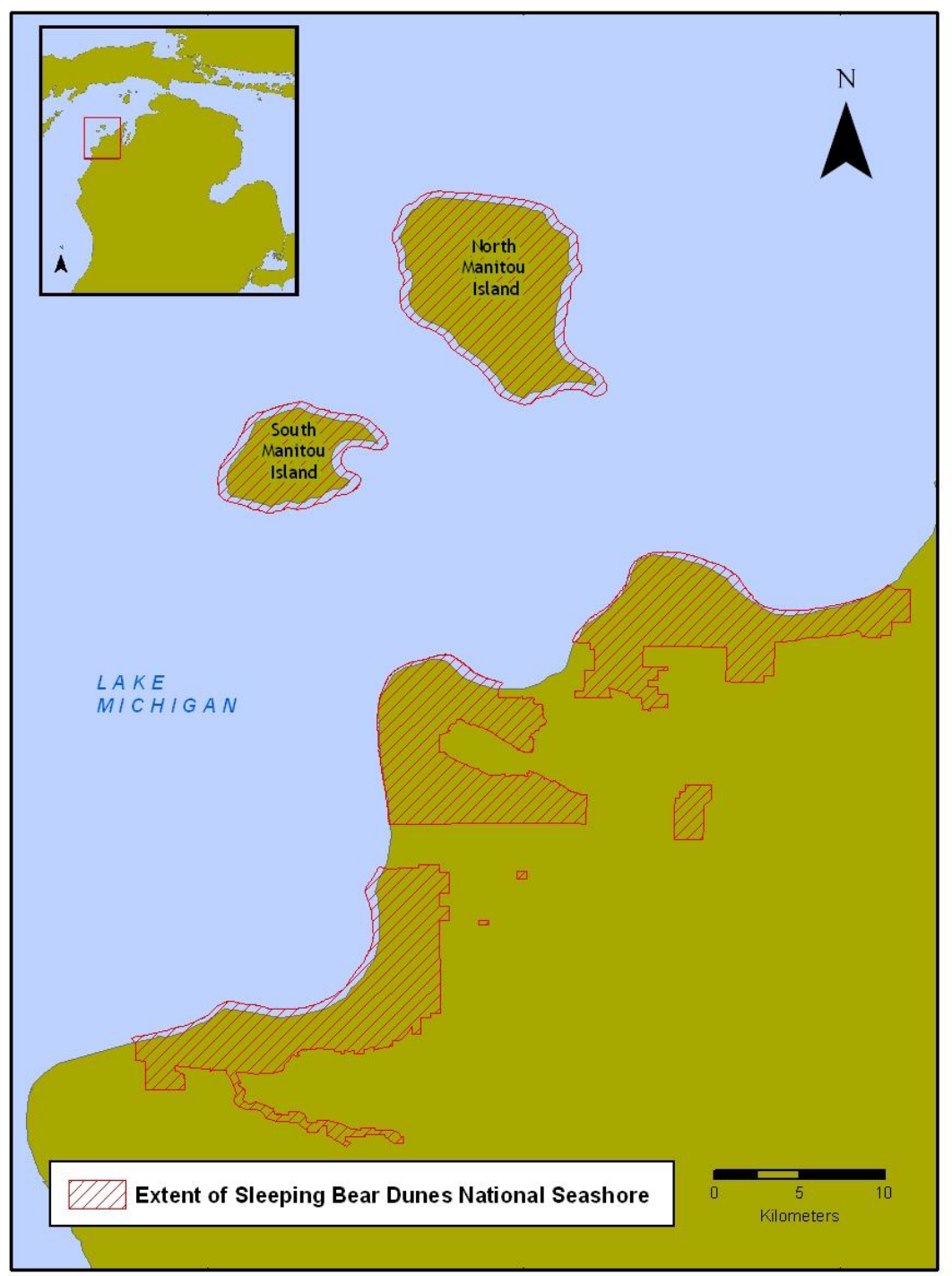

Figure 25. Location map of Sleeping Bear Dunes National Lakeshore (SLBE). 


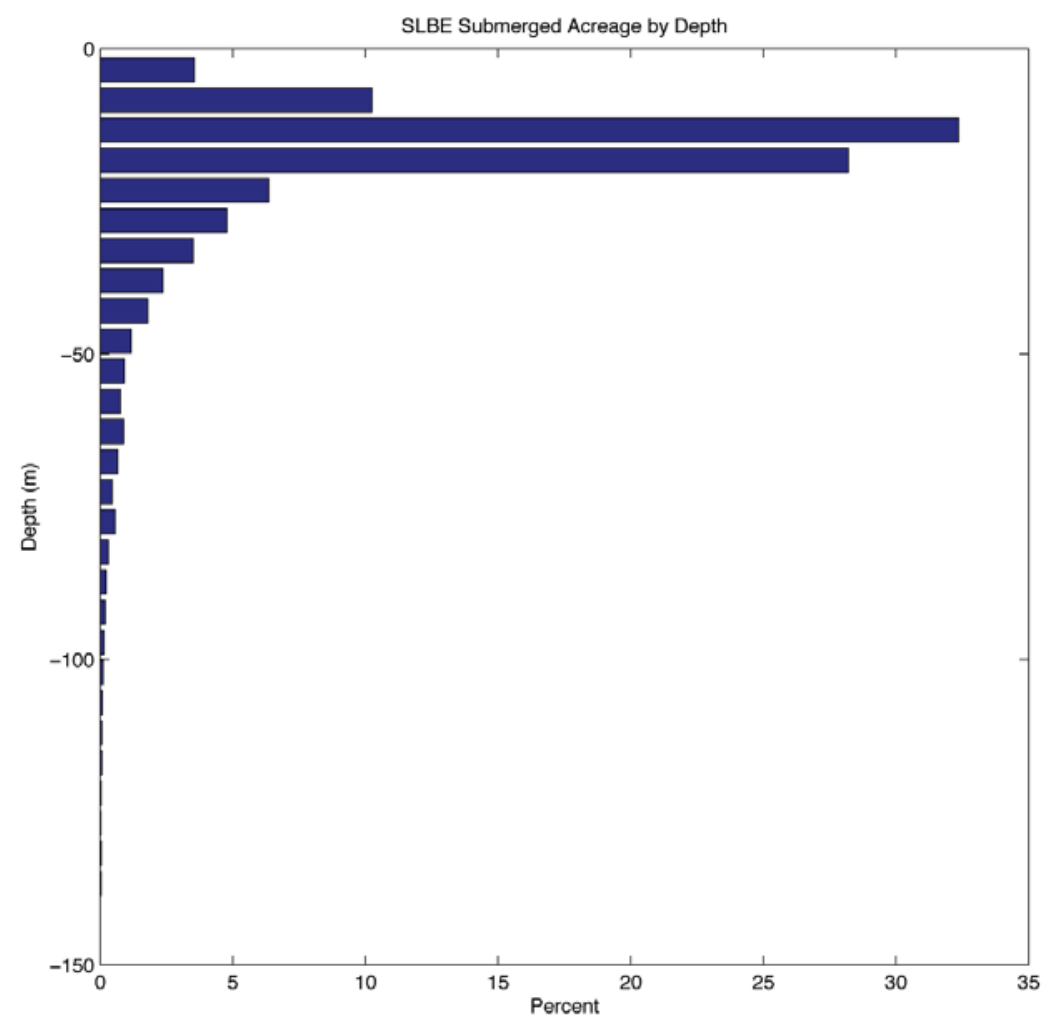

Figure 26. Histogram of Sleeping Bear Dune National Lakeshore (SLBE) submerged acreage of all classified habitats by depth.

\section{Environmental Concerns}

\section{Lake Trout}

The lake trout (Salvelinus namaycush) has been a primary focus of environmental restoration in Lake Michigan since the 1960s (Bronte, 2008). Despite management efforts, lake trout populations have declined steadily since 2000 as predation from the invasive sea lamprey has increased (Woldt and others, 2005; Bronte, 2008). Preservation of lake trout preferred spawning habitat, which recent studies identify as rocky substrate in a depth range of 36 to $42 \mathrm{~m}$ (Warner and others, 2009), is key to restoring populations. Thorough benthic mapping will facilitate the conservation and management of the lake trout breeding habitats.

\section{Zebra Mussel}

The zebra mussel (Dreissena polymorpha), a native Russian species, invaded the Great Lakes in 1988 and spread through Lake Michigan in the early 1990s (Fleischer and others, 2001; Qualls and others, 2007). Zebra mussels negatively impact the lake ecosystem by filtering large volumes of lake water, which reduces plankton abundance and chlorophyll concentrations, thereby clarifying the water and increasing the depth of sunlight penetration (Qualls and others, 2007). The zebra mussel also causes problems for industry and development on Lake Michigan by fouling underwater structures and blocking intake or outflow pipes. Control of the zebra mussel seems impossible even with modern 
technology because of the hardiness of the species, the size of the Great Lakes, and the lack of any species-specific toxin or biological control (Great Lakes Science Center, 2007a).

\section{Cladophora Algae}

Cladophora is a native filamentous green alga of the Great Lakes that is loosely attached to the bottom and that can become a smelly nuisance when wind and waves cause it to break loose and wash up on shore. The concentration of Cladophora in nearshore $(<10 \mathrm{~m})$ waters has increased in response to filtering of the water column by zebra mussels. The increase in light penetration exposes more benthic surface area to colonization by Cladophora. In addition, modification of phosphorous availability through the consumption of phytoplankton and remobilization of phosphorous by zebra mussels provides an increased nutrient supply for Cladophora (Hecky and others, 2004; Qualls and others, 2007).

\section{Invasive Fish Species}

There are several invasive fish species in the Great Lakes, most notably ruffe (Gymnocephalus cernuus) and round goby (Neogobius melanostomus). The ruffe is a native of Europe and Asia that was first seen in the Great Lakes in 1986. These small fish displace native perch through rapid reproduction. The round goby is a mid-size (17-22 cm, adult length) fish that is native to Eastern Europe. Round goby are prolific spawners and aggressive, traits that allow them to rapidly displace native fish that prefer the same rocky benthic habitats (Great Lakes Science Center, 2007b). Management of both of these invasive species is key to habitat preservation for native species.

\section{Available Benthic Data and Map Products}

SLBE data and product sources described in paragraphs 1-6 below are listed in table 3 (at the end of this section).

\section{Bathymetry}

Lake Michigan- A 60-m bathymetry grid was compiled from soundings collected by the USACE during surveys in 1921, 1922, and 1948. This dataset, part of the Great Lakes bathymetry initiative, is the result of a collaboration between the NOAA NGDC, the Great Lakes Environmental Research Laboratory (GLERL), and the Canadian Hydrographic Service (fig. 27). 


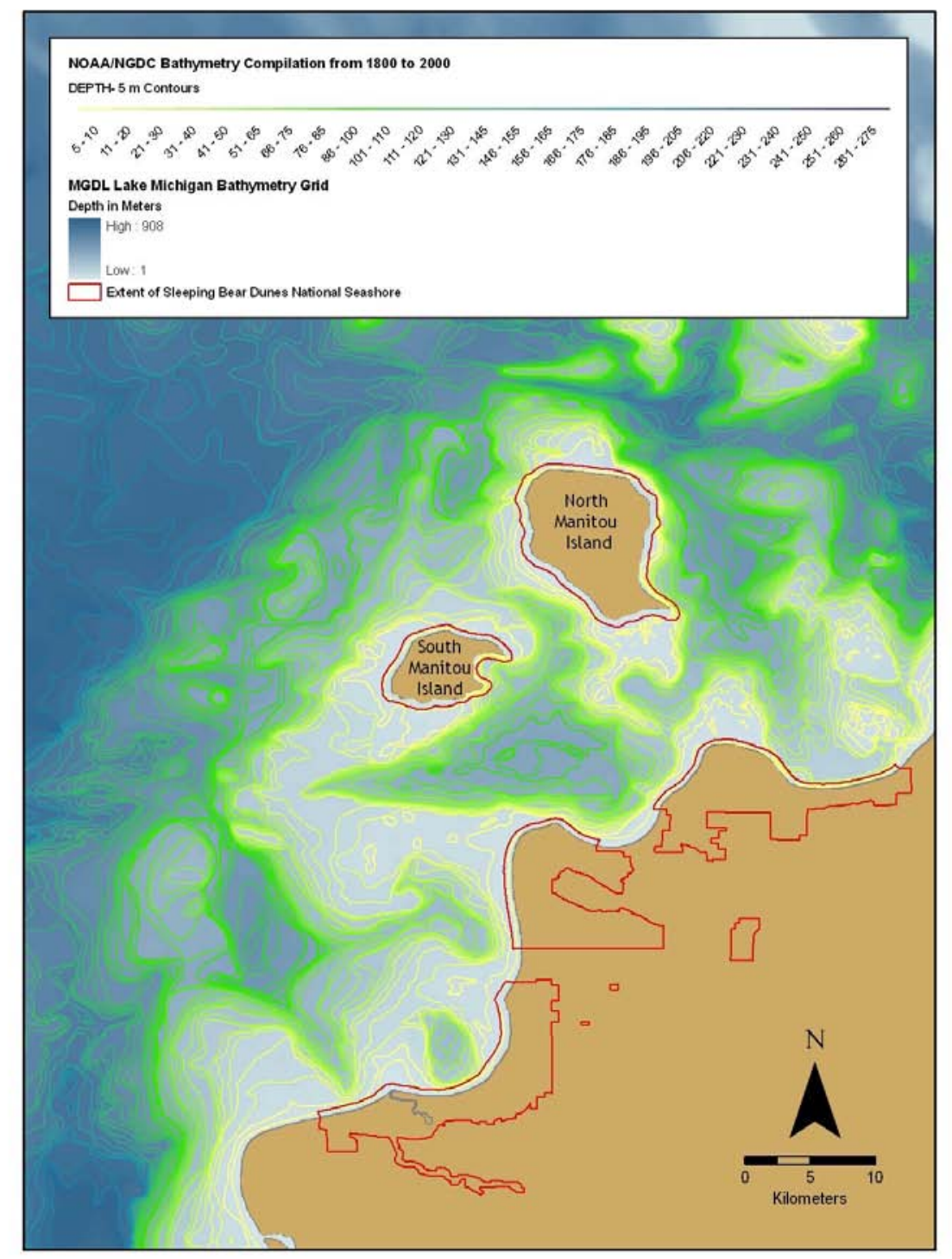

Figure 27. NOAA NGDC 60-meter bathymetry grid of Lake Michigan with 5-meter contours.

2005 USACE JALBTCX/CHARTS topobathymetric lidar data (2-m resolution) were collected in 2005 over the entire submerged acreage of SLBE (fig. 28) under the National Coastal Mapping Program. Data over North and South Manitou Islands were acquired in 2007; the mainland shore data for Leelanau and Benzie Counties within the park boundary were acquired in 2008. Coverage often extends $>400 \mathrm{~m}$ lakeward and up to $25 \mathrm{~m}$ depth, but deeper waters remain unsurveyed. Data gaps due to highly turbid water in the nearshore zone are prevalent around North Manitou Island. Coverage is nearly continuous around South Manitou Island, with the exception of the coastline between Sandy Point and Gull Point on the eastern island, where bathymetric data are absent. 


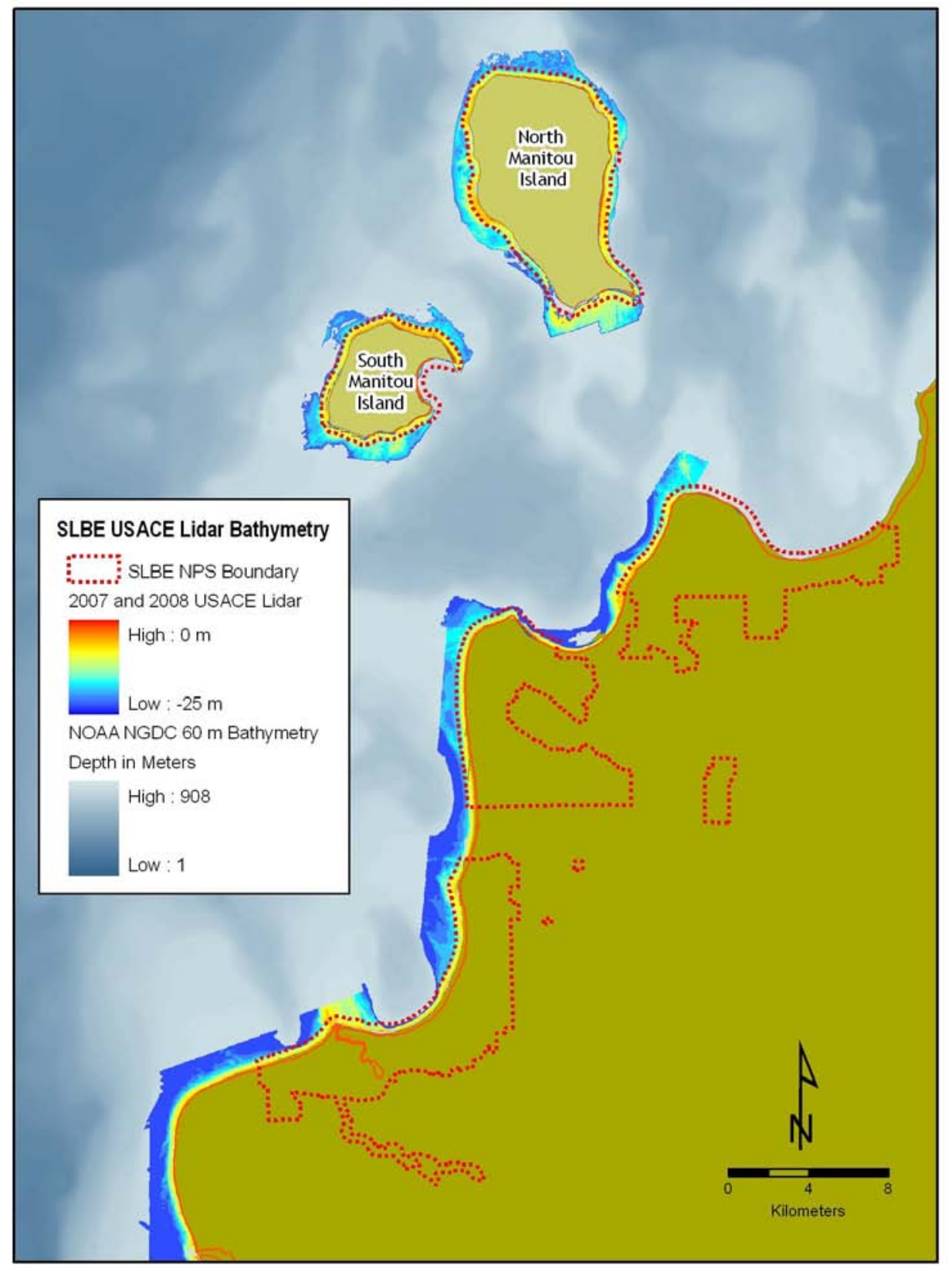

Figure 28. Extent of USACE 2005 and 2008 lidar bathymetry surveys at Sleeping Bear Dunes National Lakeshore (SLBE).

\section{Benthic Habitat Data}

An NPS-USGS collaboration to survey the benthic environment around South Manitou Island began in 2008. Adverse weather conditions prevented completion of the survey in 2008, but work 
resumed in 2009. As of summer 2010, all fieldwork and the initial sidescan processing and underwater video post-assessment have been completed (Ulf Gafvert, NPS Great Lakes Network, oral commun., 2010, and Greg Kennedy, USGS Great Lakes Science Center, oral commun., 2010). The survey used sidescan sonar, validated with underwater video and dive images, to map the submerged areas within the extent of the USACE lidar bathymetry (fig. 29). Shore-parallel and shore-perpendicular tracklines around the island were planned based on a 150 -m wide sidescan swath to yield almost 100 percent coverage of the survey area.

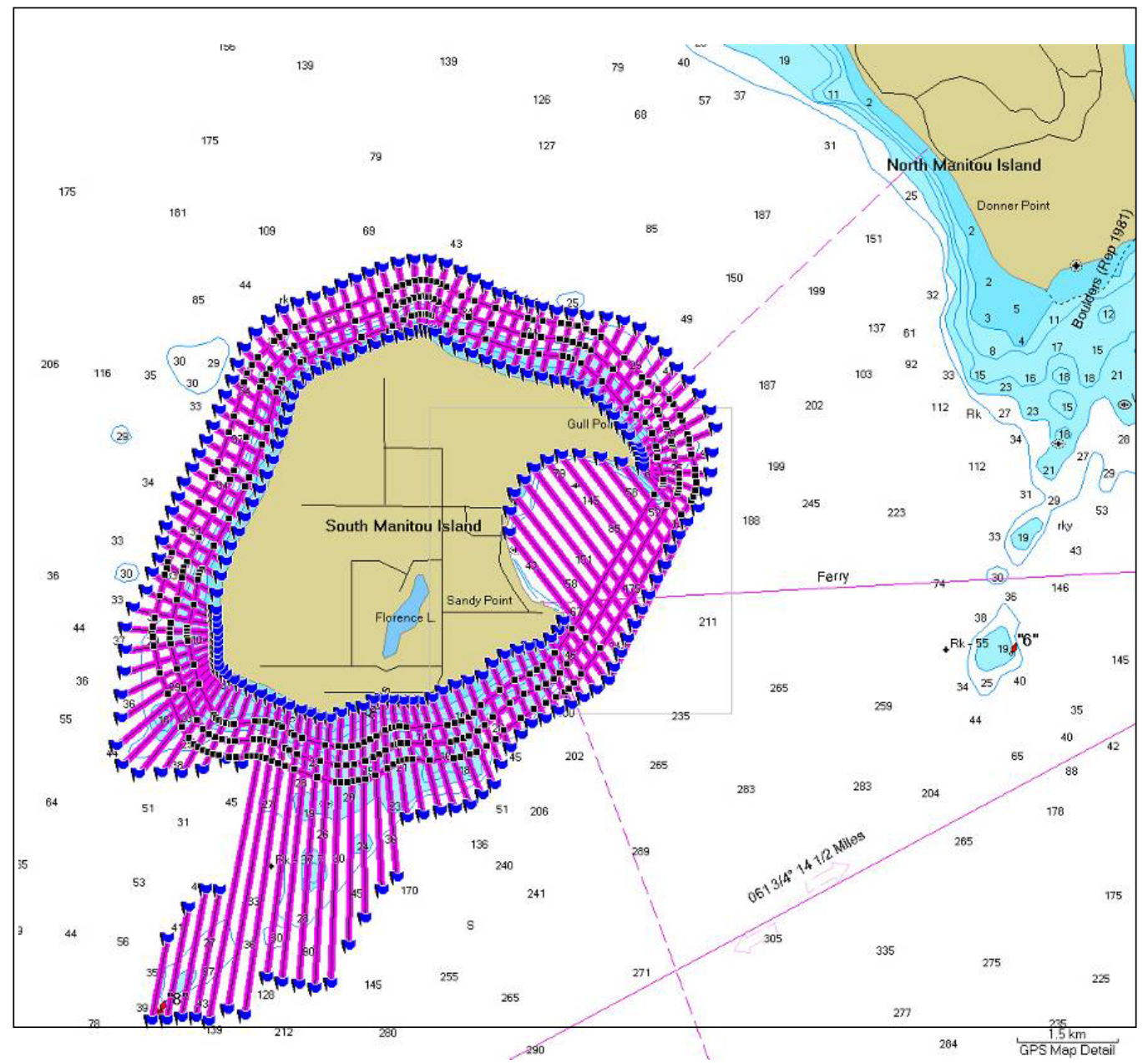

Figure 29. Planned USGS benthic habitat survey tracklines around South Manitou Island, Mich. (image courtesy of Greg Kennedy, USGS Great Lakes Science Center).

\section{Extent of the South Manitou Island Benthic Survey}

- Shore-parallel tracklines consisted of 41 transects following the island contours from the 2-m depth contour to the 10-m depth contour (fig. 30).

- Shore-perpendicular tracklines consisted of 140 transects radiating out from around the island. Transects averaged $1.2 \mathrm{~km}$ in length but extended farther than $5 \mathrm{~km}$ on the southeast side to provide coverage of the shallow offshore shoal (fig. 31).

- Six-hundred forty-two underwater video and dive "spot" surveys were conducted from the survey vessel at random locations throughout the sidescan survey area. An additional 186 
underwater images were taken in the nearshore zone (from 2-m depth to the shoreline) using kayaks and dive cameras (fig. 32).

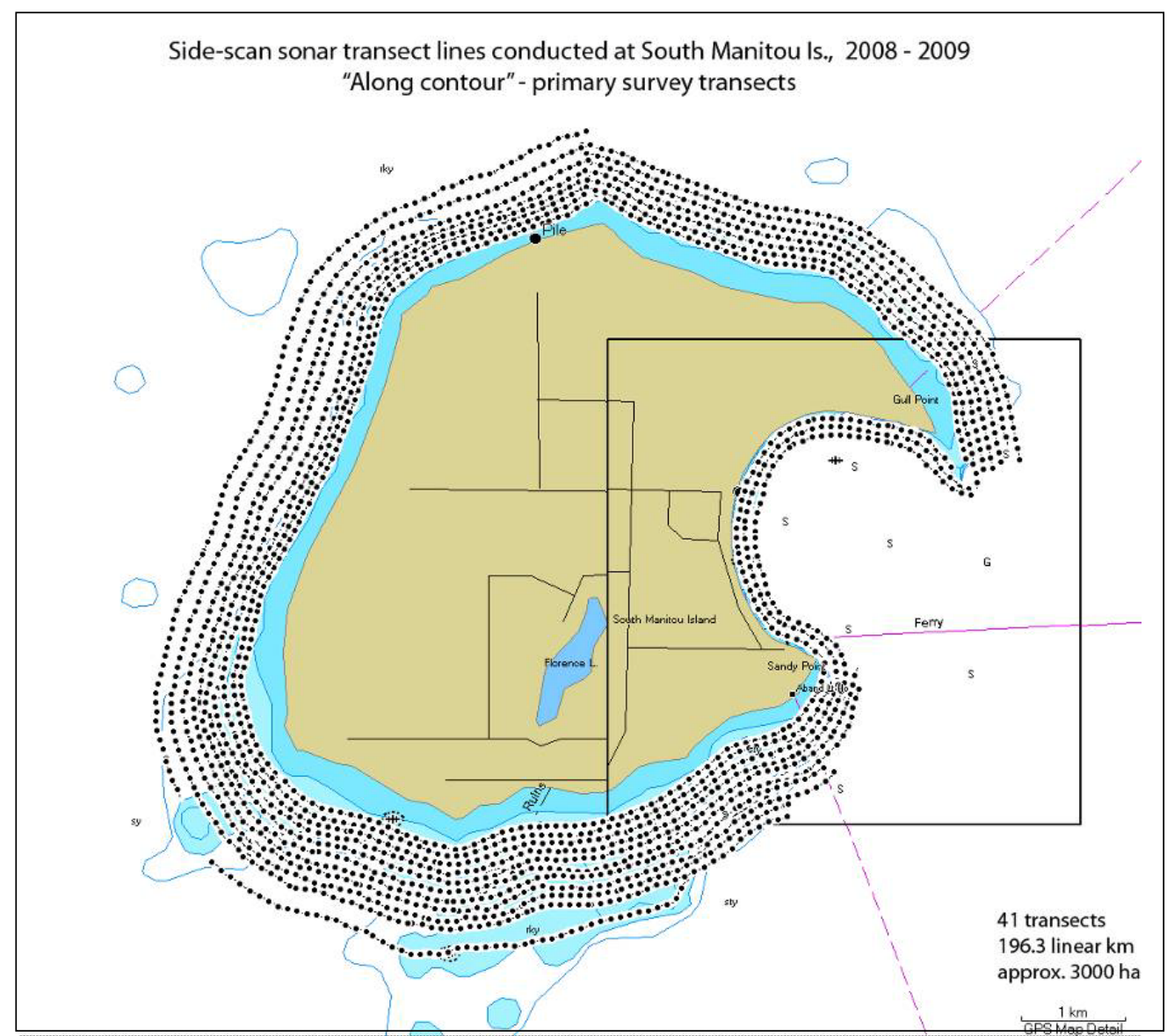

Figure 30. Completed USGS shore-parallel sidescan survey tracklines around South Manitou Island, Michigan, 2008 and 2009 (image courtesy of Greg Kennedy, USGS, Great Lakes Science Center). 


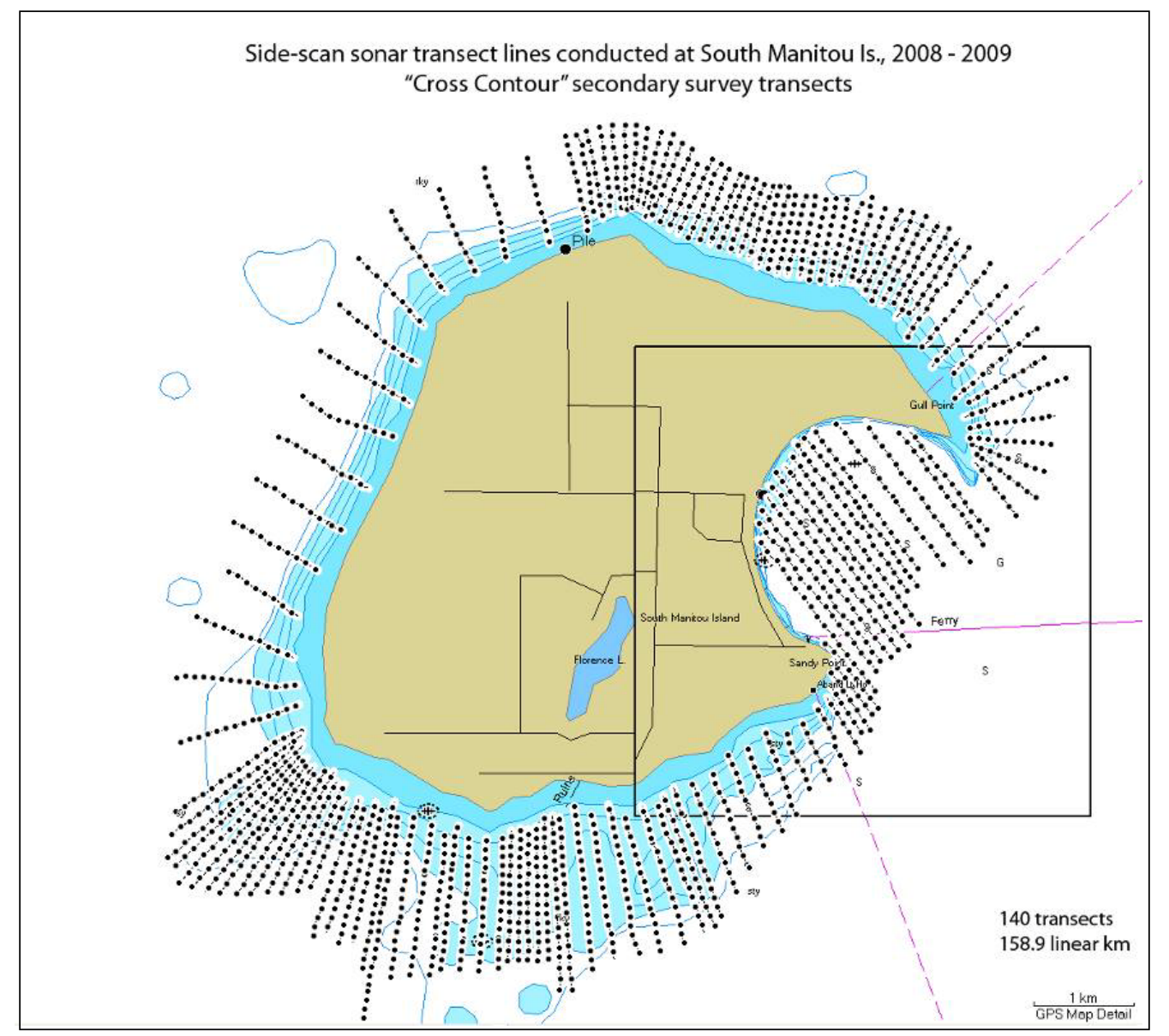

Figure 31. Completed USGS shore-perpendicular sidescan survey tracklines around South Manitou Island, Michigan, 2008 and 2009 (image courtesy of Greg Kennedy, USGS, Great Lakes Science Center). 


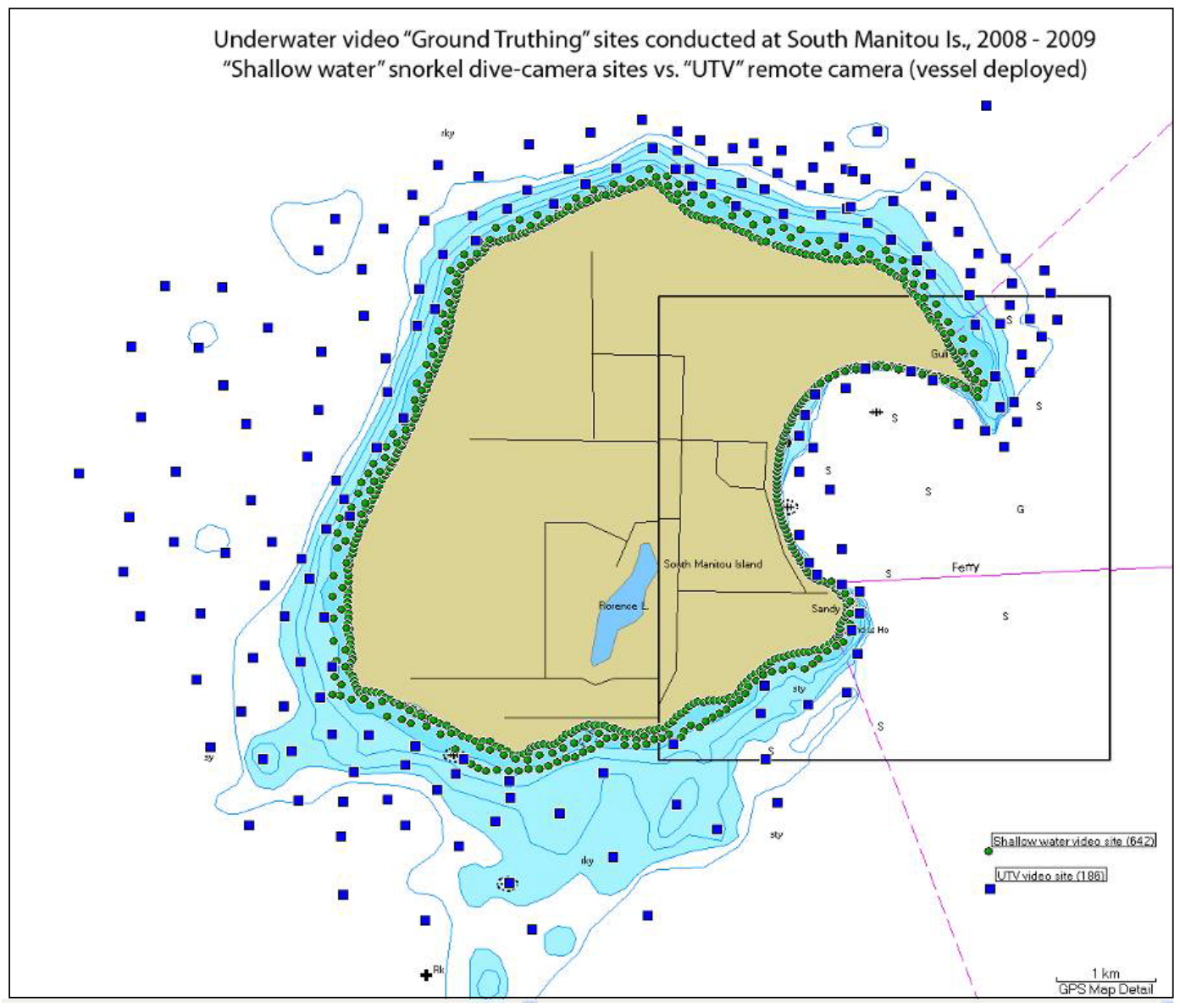

Figure 32. USGS video ground-truthing sites around South Manitou Island, Michigan, 2008 and 2009 (image courtesy of Greg Kennedy, USGS, Great Lakes Science Center).

\section{Aerial Imagery}

As with the other pilot parks, aerial imagery can be useful in deriving historic shorelines, identifying erosional trends, and mapping the extent of nearshore habitats where water clarity permits. Bottom-ground visibility may only exist in portions of individual photographs, depending on local conditions at the time. Available high-resolution imagery includes:

- NPS 0.15-m resolution color photography of North and South Manitou Islands from spring and fall 2007 with exceptional water clarity, allowing visibility up to 20 m (fig. 33),

- USGS 1-m resolution black and white photography from 1993 with visibility up to $8 \mathrm{~m}$ deep, and

- $\quad$ USDA NAIP imagery of Leelanau County at 1- to 2-m spatial resolution for 1992, 1998, 2005, 2006, and 2009. 


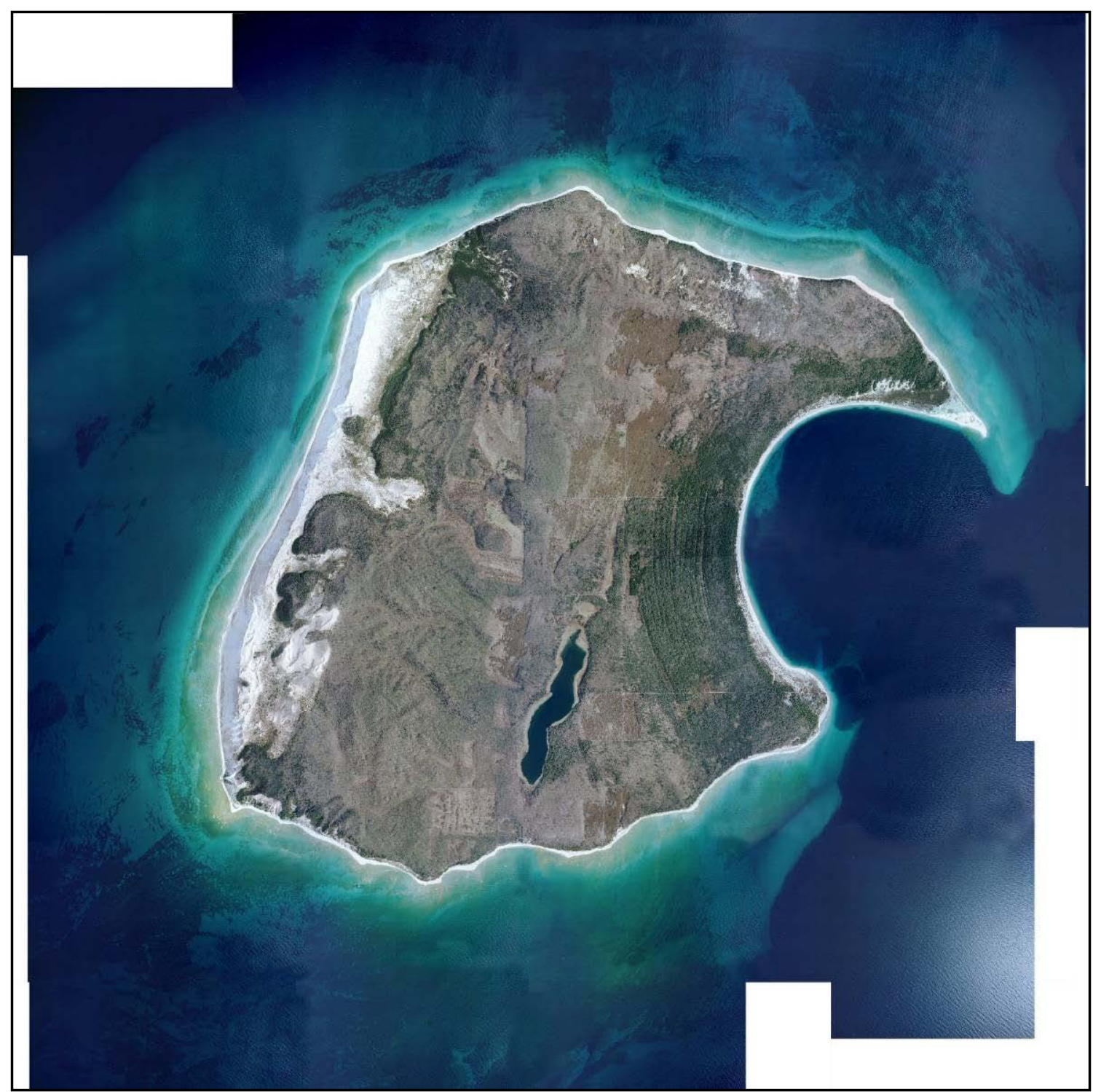

Figure 33. NPS 2007 0.15-meter resolution color photography of South Manitou Island, Michigan, with visibility of up to 20 meters deep (photo courtesy of Ulf Gafvert, NPS Great Lakes Network).

Table 3. Sleeping Bear Dunes National Seashore (SLBE) GIS datasets and imagery (corresponding to numbered paragraphs above).

[Acronyms are listed in Appendix A]

\begin{tabular}{llcll}
\hline \multicolumn{1}{c}{ Description } & Dates & Source & \\
\hline 1 & $\begin{array}{l}\text { NOAA NGDC Lake } \\
\text { Michigan bathymetry }\end{array}$ & $\begin{array}{l}1921- \\
1948\end{array}$ & NOAA NGDC & http://www.ngdc.noaa.gov/mgg/greatlakes/greatlakes.html \\
\hline 2 & USACE 2005 CHARTS lidar & 2005 & $\begin{array}{l}\text { USACE } \\
\text { JALBTCX }\end{array}$ & http://shoals.sam.usace.army.mil/ \\
\hline 3 & $\begin{array}{l}\text { NPS-USGS benthic habitat } \\
\text { data }\end{array}$ & $\begin{array}{l}2008- \\
2009\end{array}$ & USGS & Contact: Greg Kennedy,gkennedy@usgs.gov \\
\hline & $\begin{array}{l}\text { NPS color aerial } \\
\text { photography- North and }\end{array}$ & 2007 & $\begin{array}{l}\text { NPS- SLBE } \\
\text { upon request }\end{array}$ & Contact: Ulf Gafvert, ugafvert@usgs.gov \\
\hline
\end{tabular}




\begin{tabular}{lllll}
\hline \multicolumn{1}{c}{ Description } & Dates & Source & URL \\
\hline $\begin{array}{l}5, \\
6\end{array}$ & \multirow{2}{*}{ USDA NAIP, USGS imagery } & $\begin{array}{l}1992- \\
2009\end{array}$ & USDA AFPO & http://www.fsa.usda.gov/FSA/apfo \\
\hline \multicolumn{2}{c}{ Administrative and Jurisdictional Boundaries } \\
\hline $\begin{array}{l}\text { Great Lakes medium-resolution } \\
\text { shoreline }\end{array}$ & & NOAA & http://coastalgeospatial.noaa.gov/data_gis.html \\
\hline SLBE boundary & $\mathbf{1 9 9 8}-$ & NPS Data & http://science.nature.nps.gov/nrdata/datastore \\
\hline
\end{tabular}

\section{Preliminary Interpretations and Products}

Although the survey data have yet to be classified, preliminary maps of Cladophora were developed from presence or absence and abundance (fig. 34) identified from 2008 underwater video and dive observations. The processed sidescan sonar imagery shows that substrate on the west side of the island is predominately sand with sand and rock on the northern and western areas. On the eastern side, the substrate ranges from rocky shoals to clay/mud. Here, a series of ridges initially identified as bedrock were found to actually be composed of hardpan clay during a scuba survey, showing the necessity of manually validating remotely sensed data (Greg Kennedy, USGS Great Lakes Science Center, oral commun., 2010). 


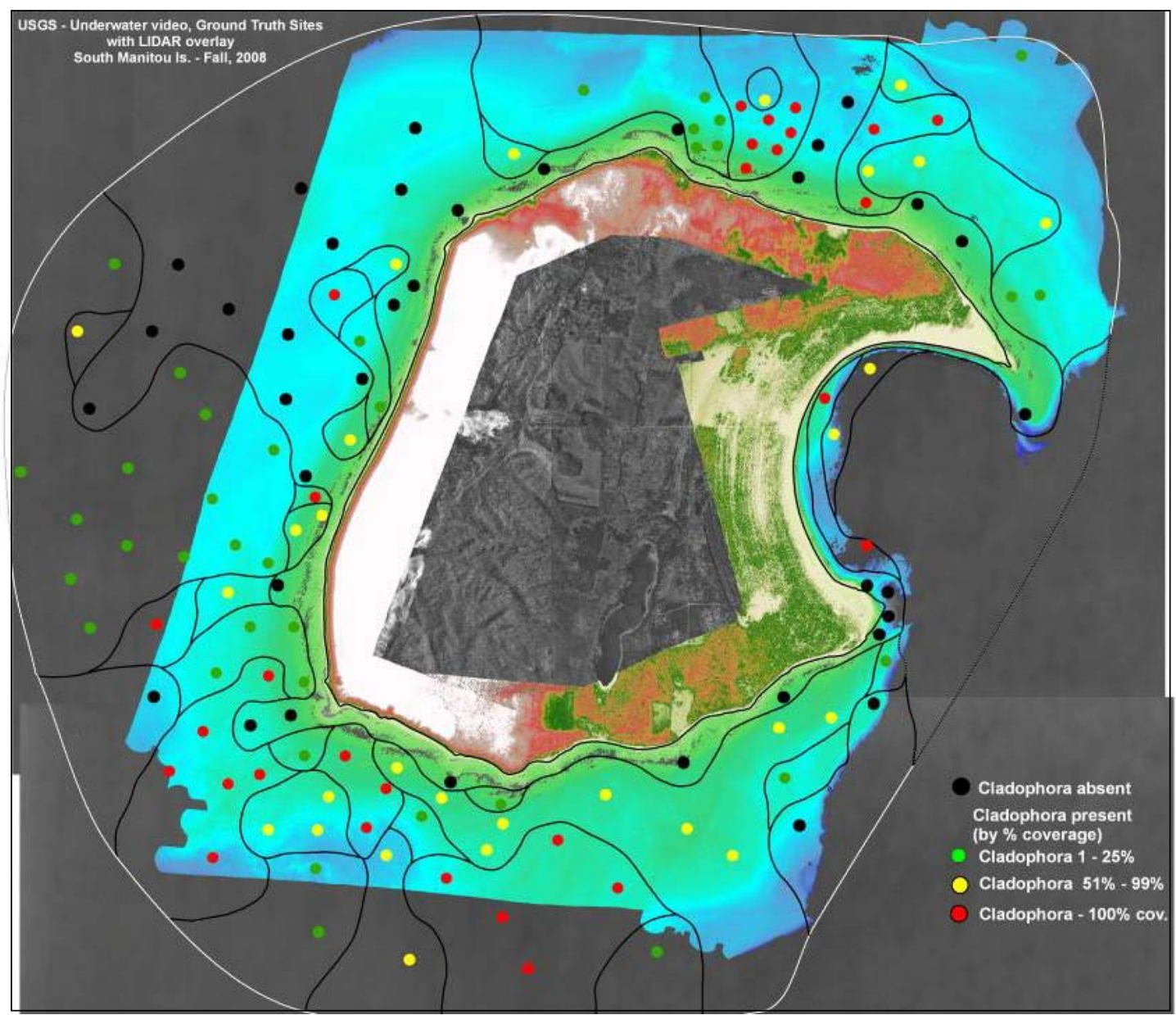

Figure 34. Cladophora locations and abundance around South Manitou Island, Michigan (image courtesy of Greg Kennedy, USGS Great Lakes Science Center).

\section{High-Priority Benthic Inventory Needs}

SLBE managers have outlined the following priorities for future research.

- Existing data from 2008-2009 South Manitou Island need to be interpreted and classified into the CMECS scheme so that benthic habitat maps of the surveyed area can be produced.

- Similar comprehensive surveys around North Manitou Island and the mainland SLBE territory are required to attain a complete identification and inventory of the park's submerged resources. Habitat data can be classified directly into CMECS without having to be reassessed from a former classification scheme.

- Acoustically derived bathymetry needs to be acquired at depths greater than $20 \mathrm{~m}$, approximately the maximum extent of the USACE lidar data.

\section{Summary}

Because the South Manitou Island benthic survey is incomplete, the benthic mapping status of SLBE is based only on the area covered by the USACE lidar bathymetry, which covers approximately 70 percent of the park's submerged area. The $I_{o}$ for SLBE, then, is 17.5 percent, 
where:

$$
I_{o}=0.25(70 \%+0 \%+0 \%+0 \%)=17.5 \%
$$

Support for the high-priority projects is forthcoming through the Great Lakes Restoration Initiative (GLRI), an interagency effort to address the ecological issues affecting the Great Lakes region funded by the President's Fiscal Year 2010 budget (Great Lakes Restoration Initiative, 2010). Although detailed plans have not yet been formulated, SLBE is in the process of hiring staff, purchasing a multibeam sidescan sonar system, and locating a dedicated vessel to carry out the remaining benthic surveys. A partnership with Northwestern Michigan College will provide SLBE with a survey vessel so that fieldwork can proceed once the multibeam system has been acquired without having to wait for delivery of its own boat (Ulf Gafvet, NPS Great Lakes Network, oral commun., 2010).

\section{Concluding Remarks}

A consistent, servicewide benthic mapping program is essential to the proper inventory and management of NPS submerged natural and anthropogenic resources. Gap analysis of three pilot parks revealed the need for substantial efforts in certain sectors of the benthic mapping process recommended by SBMP. This study also clarified that each pilot park has a different set of needs. ASIS primarily needs to focus its future mapping activities on the ocean side of the island. CHIS requires surveying and mapping in areas where data are absent. In addition, its numerous existing benthic maps should be converted (cross-checked) to the CMECS mapping standard. SLBE is making good progress with the comprehensive inventorying of South Manitou Island but needs to extend that effort to the remainder of the park's submerged acreage. 


\section{APPENDIX A: Abbreviations and Acronyms}

ALACE- Airborne Lidar Assessment of Coastal Erosion

ALI- Advanced Land Imager

ALPS- Airborne Lidar Processing System

ASCII- American Standard Code for Information Interchange

ASIS- Assateague Island National Seashore

ATM II- Advanced Thematic Mapper II

BCC- Benthic Cover Component of CMECS

BOEMER- Bureau of Energy Management, Regulation and Enforcement

CDFG- California Department of Fish and Game

CHARTS- Compact Hydrographic Airborne Rapid Total Survey

CHIS- Channel Islands National Park

CINMS- Channel Islands National Marine Sanctuary

CIR- Color Infrared

CMECS- Coastal and Marine Ecological Classification Standard

CSUMB- California State University - Monterey Bay

DEM- Digital Elevation Model

DOQQ- Digital Orthophoto Quarter Quadrangle

EAARL- Experimental Advanced Airborne Research Lidar

EPA- Environmental Protection Agency

ESRI- Environmental Systems Research Institute 
FEMA- Federal Emergency Management Agency

FGDC- Federal Geographic Data Committee

GFC- Geoform Component of CMECS

GIS- Geographic Information System

GLERL- Great Lakes Environmental Research Laboratory

GLRI- Great Lakes Research Initiative

GPS- Global Positioning System

I\&M- NPS Inventory \& Monitoring

IMAC- NPS Inventory \& Monitoring Advisory Committee

JALBTCX- Joint Airborne Lidar Technical Center of Expertise

LIDAR- Light Detection and Ranging; does not need to be capitalized

MCA- Marine Conservation Area

MD DNR- Maryland Department of Natural Resources

MR- Marine Reserve

MHW- Mean High Water

NAIP- National Agriculture Imagery Program

NAPP- National Aerial Photography Program

NER- Northeast Region of the NPS

NGDC- National Geophysical Data Center

NOAA- National Oceanic and Atmospheric Administration

NOS- National Ocean Service

NPS- National Park Service

OCTI-E- Offshore and Coastal Technologies. Inc. - East Coast 
PDF- Adobe Portable Document Format file

ROV- Remotely Operated Vehicle

SAV- submerged aquatic vegetation (for example, seagrass)

SBC- Sub-Benthic Component of CMECS

SBMP- Servicewide Benthic Mapping Program

SGC- Surface Geology Component of CMECS

SLBE- Sleeping Bear Dunes National Lakeshore

SPOT- Satellite Pour l’Observation de la Terre

SST- Sea Surface Temperatures

USACE- U.S. Army Corps of Engineers

USDA- U.S. Department of Agriculture

USFWS- U.S. Fish and Wildlife Service

USGS- U.S. Geological Survey

VIMS- Virginia Institute of Marine Sciences

WCC- Water Column Component of CMECS 
APPENDIX B: Ocean and Great Lake Parks with Submerged Acreage

\section{$\begin{array}{lllll}\text { Park Name } & \text { NPS Region } & \text { State } & \text { Water }\left(\mathrm{km}^{2}\right) & \text { Coastline }(\mathrm{km})\end{array}$}

\begin{tabular}{|c|c|c|c|c|c|c|}
\hline 1 & Acadia National Park & $\mathrm{NE}$ & $\mathrm{ME}$ & 48 & 84 & \\
\hline 2 & $\begin{array}{l}\text { Apostle Islands National } \\
\text { Lakeshore }\end{array}$ & MW & WI & 109 & 248 & \\
\hline 3 & $\begin{array}{l}\text { Assateague Island National } \\
\text { Seashore }\end{array}$ & $\mathrm{SE}$ & MD, VA & 126 & 138 & \\
\hline 4 & Biscayne National Park & SE & FL & 675 & 80 & 18 \\
\hline 5 & $\begin{array}{l}\text { Buck Island Reef National } \\
\text { Monument }\end{array}$ & SE & VI & 75 & 5 & 1,703 \\
\hline 6 & Cabrillo National Monument & PW & CA & 0.5 & 2 & 10 \\
\hline 7 & Canaveral National Seashore & SE & FL & 159 & 39 & \\
\hline 8 & Cape Cod National Seashore & NE & MA & 66 & 80 & \\
\hline 9 & Cape Hatteras National Seashore & SE & NC & 16 & 246 & \\
\hline 10 & Cape Lookout National Seashore & SE & NC & 79 & 90 & \\
\hline 11 & Channel Islands National Park & PW & CA & 497 & 283 & 387 \\
\hline 12 & $\begin{array}{l}\text { Cumberland Island National } \\
\text { Seashore }\end{array}$ & SE & GA & 41 & 48 & \\
\hline 13 & Dry Tortugas National Park & $\mathrm{SE}$ & FL & 259 & 6 & 33 \\
\hline 14 & Everglades National Park & SE & FL & 2,500 & 250 & 8 \\
\hline 15 & Fire Island National Seashore & $\mathrm{NE}$ & NY & 18 & 84 & \\
\hline 16 & Fort Sumter National Monument & SE & SC & 0.5 & 2 & \\
\hline 17 & $\begin{array}{l}\text { Gateway National Recreation } \\
\text { Area }\end{array}$ & $\mathrm{NE}$ & NY & 72 & & \\
\hline 18 & $\begin{array}{l}\text { Glacier Bay National Park and } \\
\text { Preserve }\end{array}$ & AK & AK & 2,406 & 1,908 & \\
\hline 19 & $\begin{array}{l}\text { Golden Gate National } \\
\text { Recreation Area }\end{array}$ & PW & CA & 15 & 45 & \\
\hline 20 & Gulf Islands National Seashore & SE & FL, MS & 461 & 122 & \\
\hline 21 & $\begin{array}{l}\text { Indiana Dunes National } \\
\text { Lakeshore }\end{array}$ & MW & IN & 2 & 40 & \\
\hline 22 & Isle Royale National Park & MW & MI & 1,752 & 544 & \\
\hline 23 & $\begin{array}{l}\text { Jean Lafitte National Historical } \\
\text { Park and Preserve, Barataria } \\
\text { Preserve }\end{array}$ & SE & LA & 0.7 & 29 & \\
\hline
\end{tabular}




\begin{tabular}{|c|c|c|c|c|c|c|}
\hline 24 & $\begin{array}{l}\text { Kalaupapa National Historical } \\
\text { Park }\end{array}$ & PW & HI & 8 & 2 & \\
\hline 25 & $\begin{array}{l}\text { Kaloko-Honokohau National } \\
\text { Historical Park }\end{array}$ & PW & HI & 2 & 3 & \\
\hline 26 & $\begin{array}{l}\text { Katmai National Park and } \\
\text { Preserve }\end{array}$ & AK & AK & 2,688 & 800 & \\
\hline 27 & $\begin{array}{l}\text { National Park of American } \\
\text { Samoa }\end{array}$ & PW & AS & 13 & 53 & \\
\hline 28 & Olympic National Park & PW & WA & 61 & 92 & \\
\hline 29 & Padre Island National Seashore & $\mathrm{IM}$ & $\mathrm{TX}$ & 130 & 106 & \\
\hline 30 & $\begin{array}{l}\text { Pictured Rocks National } \\
\text { Lakeshore }\end{array}$ & MW & MI & 39 & 76 & \\
\hline 31 & Point Reyes National Seashore & PW & CA & 88 & 290 & \\
\hline 32 & $\begin{array}{l}\text { Puukohola Heiau National } \\
\text { Historic Site }\end{array}$ & PW & $\mathrm{HI}$ & 0.1 & 2 & \\
\hline 33 & Redwood National Park & PW & CA & 24 & 58 & \\
\hline 34 & $\begin{array}{l}\text { Salt River Bay National Historic } \\
\text { Park and Ecological Preserve }\end{array}$ & $\mathrm{SE}$ & VI & 2 & 2 & \\
\hline 35 & Sitka National Historic Park & AK & AK & 0.2 & 2 & \\
\hline 36 & $\begin{array}{l}\text { Sleeping Bear Dunes National } \\
\text { Lakeshore }\end{array}$ & MW & MI & 42 & 76 & \\
\hline 37 & $\begin{array}{l}\text { Timucuan Ecological and } \\
\text { Historic Preserve }\end{array}$ & $\mathrm{SE}$ & FL & 152 & 2 & \\
\hline 38 & $\begin{array}{l}\text { Virgin Islands Coral Reef } \\
\text { National Monument }\end{array}$ & SE & VI & 56 & 5 & \\
\hline 39 & Virgin Islands National Park & $\mathrm{SE}$ & VI & 23 & 35 & 25 \\
\hline 40 & $\begin{array}{l}\text { War in the Pacific National } \\
\text { Historical Park }\end{array}$ & PW & GU & 4 & 6 & \\
\hline
\end{tabular}




\section{References Cited}

Bonisteel, J.M., Nayegandhi, Amar, Brock, J.C., Wright, C.W., Stevens, Sara, Yates, Xan, and Klipp, E.S., 2009a, EAARL coastal topography-Assateague Island National Seashore, 2008: First Surface: U.S. Geological Survey Data Series 446, 1 DVD, available at http://pubs.usgs.gov/ds/446/.

Bonisteel, J.M., Nayegandhi, Amar, Brock, J.C., Wright, C.W., Stevens, Sara, Yates, Xan, and Klipp, E.S., 2009b, EAARL coastal topography-Assateague Island National Seashore , 2008: Bare Earth: U.S. Geological Survey Data Series 447, 1 DVD, available at http://pubs.usgs.gov/ds/447/.

Brock, J.C., Wright, C.W., Patterson, Matt, Nayegandhi, Amar, and Travers, L.J., 2007, EAARL topography-Assateague Island National Seashore: U.S. Geological Survey Open-File Report 20071176, available at http://pubs.usgs.gov/of/2007/1176/.

Bronte, C.R., 2008, Lake trout rehabilitation: Special Publication, Great Lakes Fishery Commission, v. 8, no. 2, p. 89-97.

California Department of Fish and Game, 2008, Master Plan for Marine Protected Areas: available at http://www.dfg.ca.gov/mlpa/pdfs/revisedmp0108.pdf, 110 p.

Carignan, K.S., Taylor, L.A., Eakins, B.W., Warnken, R.R., Lim, E., and Medley, P.R., 2009, Digital Elevation Model of Santa Barbara, California: Procedures, data sources and analysis: NOAA National Geophysical Data Center, 30 p., available at http://www.ngdc.noaa.gov/mgg/inundation.

Casey, K.S., and Cornillon, P., 2001, Global and regional sea surface temperature trends: Journal of Climate, v. 14, no. 18, p. 3801-3818.

Cochrane, G.R., Conrad, J.E., Reid, J.A., Fangman, Sarah, and Golden, Nadine, 2005, The nearshore benthic habitat GIS for the Channel Islands National Marine Sanctuary and southern California state fisheries reserves, Volume II: U.S. Geological Survey Open-File Report 2005-1170, available at http://pubs.usgs.gov/of/2005/1170/.

Cochrane, G.R., Nasby, N.M., Reid, J.A., Waltenberger, Ben, and Lee, K.M., 2003, Nearshore benthic habitat GIS for the Channel Islands National Marine Sanctuary and southern California state fisheries reserves, Volume 1: U.S. Geological Survey Open-File Report 03-85, available at http:geopubs.wr.usgs.gov/open-file/of03-85/.

Cogan, C.B., and Noji, T.T., 2007, Marine classification, mapping, and biodiversity analysis, in Todd, B.J., and Greene, H.G., eds., Mapping the seafloor for habitat characteristics: Geological Association of Canada, Special Paper 47, p. 129-139.

Conkwright, R.D., 1975, Historical shorelines and erosion rates atlases: Maryland Geological Survey, Baltimore, Md., 4 volumes.

Curdts, T., 2011, Shoreline length and water area in the ocean, coastal and Great Lakes parks: Updated statistics for shoreline miles and water acres: Natural Resource Report NPS/WASO/NRR2011/282. National Park Service, Fort Collins, Colorado, 52 p.

Done, T., and Jones, R., 2006, Tropical coastal ecosystems and climate change prediction: Global and local risks, in Phinney, J.T., Hoegh-Guldberg, O., Kleypas, J., Skirving, W., and Strong, A.E., eds., Coral reefs and climate change: Science and management: Washington, D.C., American Geophysical Union, p. 5-32.

Fleischer, G.W., DeSorcie, T.J., and Holuszko, J.D., 2001, Lake-wide distribution of Dreissena in Lake Michigan, 1999: Journal of Great Lakes Research, v. 27, no. 2, p. 252-257.

Folk, R.L., 1954, The distinction between grain size and mineral composition in sedimentary-rock nomenclature: Journal of Geology, v. 62, no. 4, p. 344-359.

Gibbs, A.E., Cochran, S.A., Logan, J.B., and Grossman, E.E., 2007, Benthic habitats and offshore geological resources of Kaloko-Honokohau National Historical Park, Hawai i: U.S. Geological 
Survey Scientific Investigations Report, 2006-5256, 62 p., available at http://pubs.usgs.gov/sir/2006/5256/.

Great Lakes Restoration Initiative, 2010, Great Lakes Restoration Initiative Action Plan, FY 2010-

FY 2014: available at http://greatlakesrestoration.us/?p=445, 41 p.

Great Lakes Science Center, 2007a, Zebra mussels cause economic and ecological problems in the Great Lakes: GLSC Fact Sheet, 2000-6, p. 1-2.

Great Lakes Science Center, 2007b, Round goby: An exotic fish in the Great Lakes: GLSC Fact Sheet, 2000-1, p. 1-2.

Greene, H.G., Bizzarro, J.J., O’Connell, V.M., and Brylinsky, C.K., 2007, Construction of digital potential marine benthic habitat maps using a coded classification scheme and its applications, in Todd, B.J., and Greene, H.G., eds., Mapping the seafloor for habitat characterization: Geological Association of Canada, Special Paper 47, p. 145-159.

Greene, H.G., Wakefield, W.W., Sullivan, D.E., McRea, J.E., Jr., Cailliet, G.M., Yoklavich, M.M., Starr, R.M., and O'Connell, V.M., 1999, A classification scheme for deep seafloor habitats: Oceanologica Acta, v. 22, no. 6, p. 663-678.

Hecky, R.E., Smith, R.E., Barton, D.R., Guildford, S.J., Taylor, W.D., Charlton, M.N., and Howell, T., 2004, The nearshore phosphorus shunt: A consequence of ecosystem engineering by dreissenids in the Laurentian Great Lakes: Canadian Journal of Fisheries and Aquatic Sciences, v. 61, no. 7, p. $1285-1293$.

Hooper, D.U., Chapin, F.S., Ewel, J.J., Hector, A., Inchausti, P., Lavorel, S., Lawton, J.H., Lodge, D.M., Loreau, M., Naeem, S., Schmid, B., Setala, H., Symstad, A.J., Vandermeer, J., and Wardle, D.A., 2005, Effects of biodiversity on ecosystem functioning: A consensus of current knowledge: Ecological Monographs, v. 75, no. 1, p. 3-35.

Hu, C., Muller-Karger, F.E., Vargo, G.A., Neely, M.B., and Johns, E., 2004, Linkages between coastal runoff and the Florida Keys ecosystem: A study of a dark plume event: Geophysical Research Letters, v. 31, no. 15, p. L15307, doi: 15310.11029/12004GL020382.

Jokiel, P.L., and Brown, E.K., 2004, Global warming, regional trends and inshore environmental conditions influence coral bleaching in Hawaii: Global Change Biology, v. 10, no. 10, p. 1627-1641.

LaPointe, B.E., 1997, Nutrient thresholds for bottom-up control of macroalgal blooms on coral reefs in Jamaica and southeast Florida: Limnology and Oceanography, v. 42, p. 1119-1131.

Madden, C., Goodin, K., Allee, B., Finkbeiner, M., and Bamford, D., 2008, Coastal and Marine Ecological Classification Standard: NOAA and NatureServe, 77 p.

Maryland Department of Natural Resources, 2005, Worcester County, Maryland LiDAR Mapping Project: NOAA Data Access Viewer: available at http://www.csc.noaa.gov/ldart.

Maryland Geological Survey, 2000, Historical shorelines, 1841-1976; Chesapeake Bay Region of Maryland, edition 1: http://www.mgs.md.gov.

Medley, P.R., Taylor, L.A., Eakins, B.W., Warnken, R.R., Carignan, K.S., Lim, E., Caldwell, R.J., and Friday, D.Z., 2009, Digital Elevation Model of Ocean City, MD: Procedures, data sources and analysis: NOAA National Geophysical Data Center, 35 p., available at http://www.ngdc.noaa.gov/mgg/inundation.

Moses, C.S., Nayegandhi, Amar, Beavers, Rebecca, and Brock, John, 2010, A Servicewide Benthic Mapping Program for National Parks: U.S. Geological Survey Open-File Report 2010-1264, available at http://pubs.usgs.gov/of/2010/1264/.

National Park Service, 2006, Assateague Island North End Restoration Project Introduction: available at http://www.nps.gov/asis/naturescience/upload/ProjectIntroduction.pdf, 5 p. 
National Park Service, 1999, Natural resource inventory and monitoring guidelines: National Park Service, NPS 75, available at http://www.nature.nps.gov/nps75/nps75.pdf, 40 p.

Nayegandhi, A., Brock, J.C., and Wright, C.W., 2009, Small-footprint, waveform-resolving lidar estimation of submerged and sub-canopy topography in coastal environments: International Journal of Remote Sensing, v. 30, no. 4, p. 861-878.

Qualls, T.M., Dolan, D.M., Reed, T., Zorn, M.E., and Kennedy, J., 2007, Analysis of the impacts of the zebra mussel, Dreissena polymorpha, on nutrients, water clarity, and the chlorophyll-phosphorus relationship in lower Green Bay: Journal of Great Lakes Research, v. 33, no. 3, p. 617-626.

Rosati, J.D., and Ebersole, B.A., 1996, Littoral impact of Ocean City Inlet, Maryland, USA, in Edge, Billy L., eds., American Society of Civil Engineers, Coastal Engineering 1996: Proceedings of the $25^{\text {th }}$ International Conference, v. 3, p. 2779-2792.

Schiff, K.C., Allen, M.J., Zeng, E.Y., and Bay, S.M., 2000, Southern California: Marine Pollution Bulletin, v. 41, no. 1-6, p. 76-93.

Shepard, F.P., 1954, Nomenclature based on sand-silt-clay ratios: Journal of Sedimentary Research, v. 24, no. 3, p. 151-158.

Warner, D.M., Claramunt, R.M., Janssen, J., Jude, D.J., and Wattrus, N., 2009, Acoustic estimates of abundance and distribution of spawning lake trout on Sheboygan Reef in Lake Michigan: Journal of Great Lakes Research, v. 35, no. 1, p. 147-153.

Woldt, A.P., Sitar, S.P., Bence, J.R., and Ebener, M.P., eds., 2005, Technical fisheries committee administrative report 2004: Status of lake trout and lake whitefish populations in the 1836 treatyceded waters of Lakes Superior, Huron and Michigan in 2003, with recommended yield and effort levels for 2004: A report submitted by the Modeling Subcommittee to the Technical Fisheries Committee: available at http://www.michigan.gov/documents/2004StatusLT\&LakeWhitefishPop_126360_7.pdf. 